(3) SIA 4 ENGINEERING DATA TRANSMITTAL ses 20 angl.

2. To: (Receiving Organization)

Distribution

5. Proj./Prog./Dept./Div.: 3. From: (originating Organization) Characterization Support

WM/Characterization

6. Cog. Engr.:

B. C. Simpson

8. Originator Remarks:

Tank Characterization Report for Single-She11 Tank 241-T105. This report contributes to the fulfillment of TPA

Milestone M-44-05

11. Receiver Remarks:

12. Major Assm. Dwg. No.:

NA

13. Permit/Permit Application No.: NA

14. Required Response Date:

Sept. 6, 1994

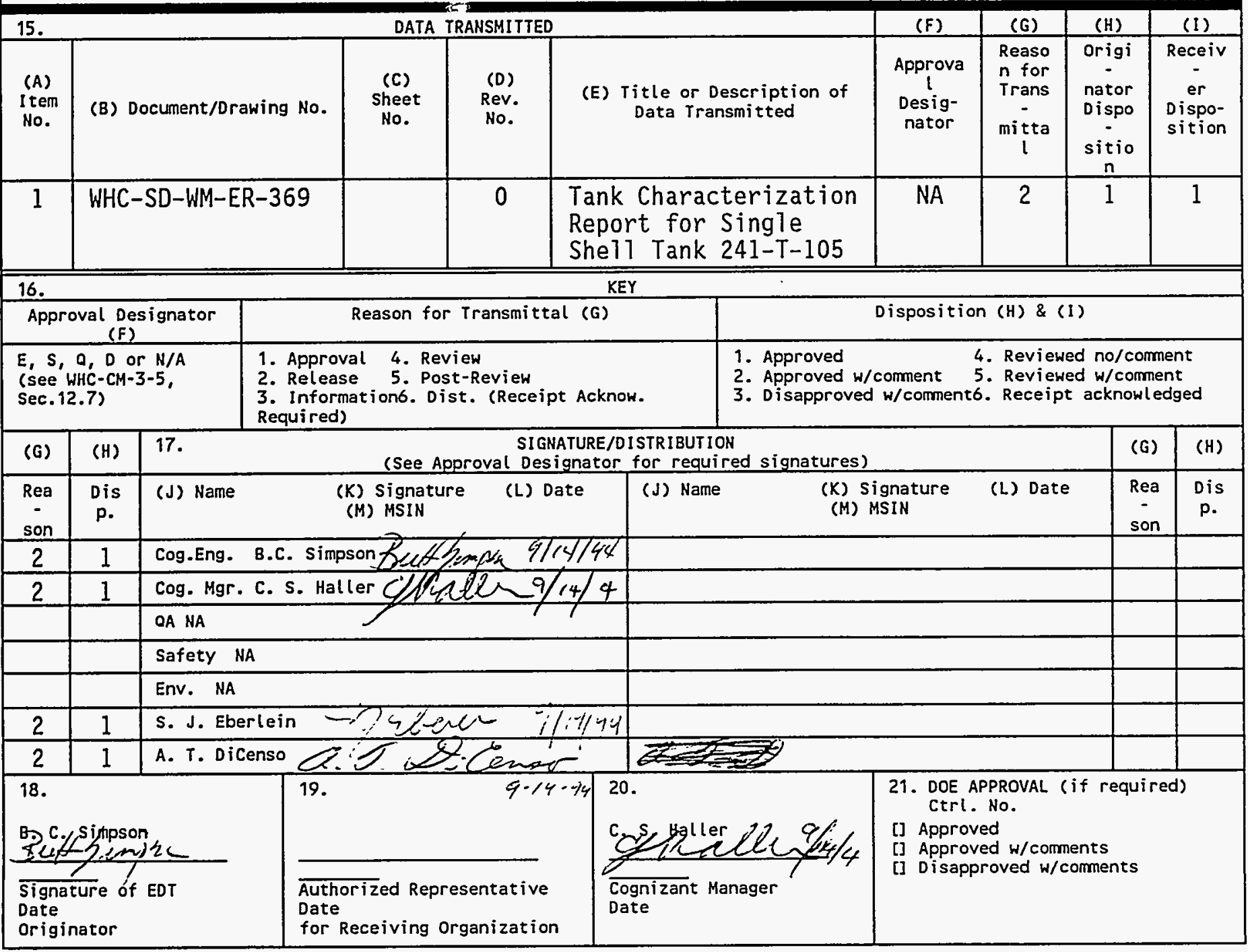

BD-7400-172-2 (04/94) GEF097 


\section{DISCLAIMER}

Portions of this document may be illegible in electronic image products. Images are produced from the best available original document. 


\section{RELEASE AUTHORIZATION}

Document Number: WHC-SD-WM-ER-369, REV.0

Document Title: Tank Characterization Report for Single-She11 Tank 241-T-105

Release Date: $\quad$ September 28, 1994

$* * * * * * * * * * * * *$

This document was reviewed following the procedures described in WHC-CM-3-4 and is:

APPROVED FOR PUBLIC RELEASE

***************

WHC Information Release Administration Specialist:

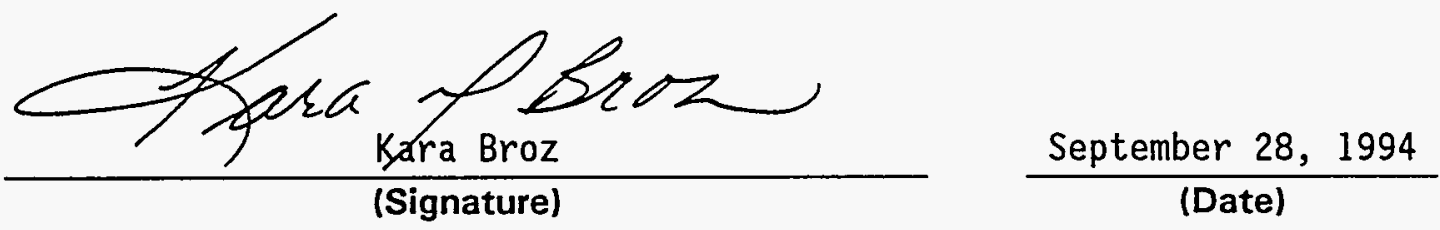


2. Title

3. Number

Tank Characterization Report for Single-She11 Tank 241-T-105

5. Key Words

Waste Characterization; Single-Shel1 Tank; T-105;

Tank Characterization Report; Waste Inventory; T

Farm; TPA Milestone M-10; TPA Milestone M-44

WHC-SD-WM-ER-369

4. Rev No.

0

6. Author

Name: A.T. DiCenso

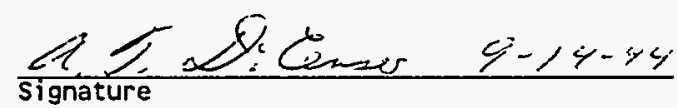

Name: B.C. Simpson

APPROVED FOA

KmB \%/2s/at PUBLIC RELEASE

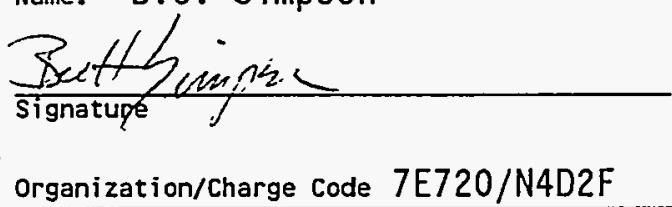

7. Abstract

This document provides the characterization information and interprets the data for Single-She11 Tank T-105

8. Purpose AND USE OF DOCUMENT - This document was prepared for use within the U.S. Department of Energy and its contractors $1 t$ is to be used onx to perform, direct, or integrat work under U.S. Department of Energy contracts. This docyment is not approved for public release untik reviewed.

PATENT STATUS - This document since it is transmitted in advance of patent clearance, is made axailable in confidence solely for use in performapee of work under contracts with the U.S. Department of Energy. This document is not to be published nor its contents gtherwise disseminated or used for purposesether than specified above before patent approval for such release or ase has been setured, upon request, from the Patent Counsel, U.S. Departmem-

DISCLAIMER - This report was prepared as an account of work sponsored by an agency of the United States Government. Neither the United States Government nor any agency thereof, nor any of their employees, nor any of their contractors, subcontractors or their employees, makes any warranty, express or implied, or assumes any legal liability or responsibility for the accuracy, completeness, or any third party's use or the results of such use of any information, apparatus, product, or process disclosed, or represents that its use would not infringe privately owned rights. Reference herein to any specific commercial product, process, or service by trade name, trademark, manufacturer, or otherwise, does not necessarily constitute or imply $i$ ts endorsement, recommendation, or favoring by the United States Government or any agency thereof or its contractors or subcontractors. The views and opinions of authors expressed herein do not necessarily state or reflect those of the United States Government or any agency thereof.

9. Impact Level NA

10.

RELEASE STAMP

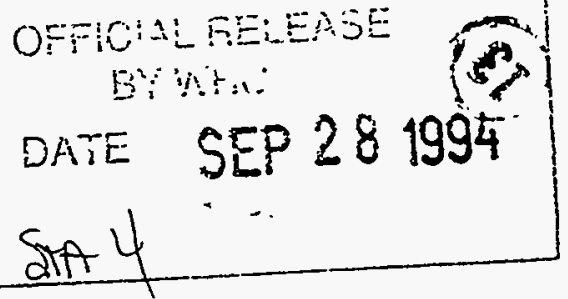




\title{
Tank Characterization Report for Single-Shell Tank 241-T-105
}

\author{
A. T. DiCenso \\ L. C. Amato \\ J. D. Franklin \\ G. L. Nuttall \\ K. W. Johnson \\ Los Alamos Technical Associates, Incorporated
}

B. C. Simpson

Westinghouse Hanford Company

Date Published

September 1994

Prepared for Westinghouse Hanford Company by Los Alamos Technical Associates 8633 Gage Blvd.

Kennewick, WA 99336

(LATA-TCR-9411) Rev. 0 


\section{EXECUTIVE SUMMARY}

Single-Shell Tank 241-T-105, an underground storage tank containing radioactive waste, was most recently sampled in March and May of 1993. Sampling and characterization of the waste in Tank 241-T-105 contribute toward the fulfillment of Milestone M-44-05 of the Hanford Federal Facility Agreement and Consent Order (Ecology, EPA, and DOE, 1993). Characterization will also provide support for the Tank Farm Operations, safety programs and design of retrieval, pretreatment, and disposal systems.

Tank 241-T-105, located in the 200 West Area T Tank Farm, was constructed in 1944 and went into service in July of 1946 by receiving second cycle decontamination waste from the T Plant. During the service life of the tank, other wastes were added including $T$ Plant first cycle waste, PUREX Plant coating waste, laboratory waste, decontamination waste from T Plant, B Plant low level waste, and $B$ Plant ion exchange waste. It is the second tank in a cascade with Tanks 241-T-104 and 241-T-106. The final disposal of the waste in Tank 241-T105 will be as high- and low-level glass fractions. The tank has an operational capacity of $2,0 \cdot 10,000 \mathrm{~L}(530,000$ gal), and

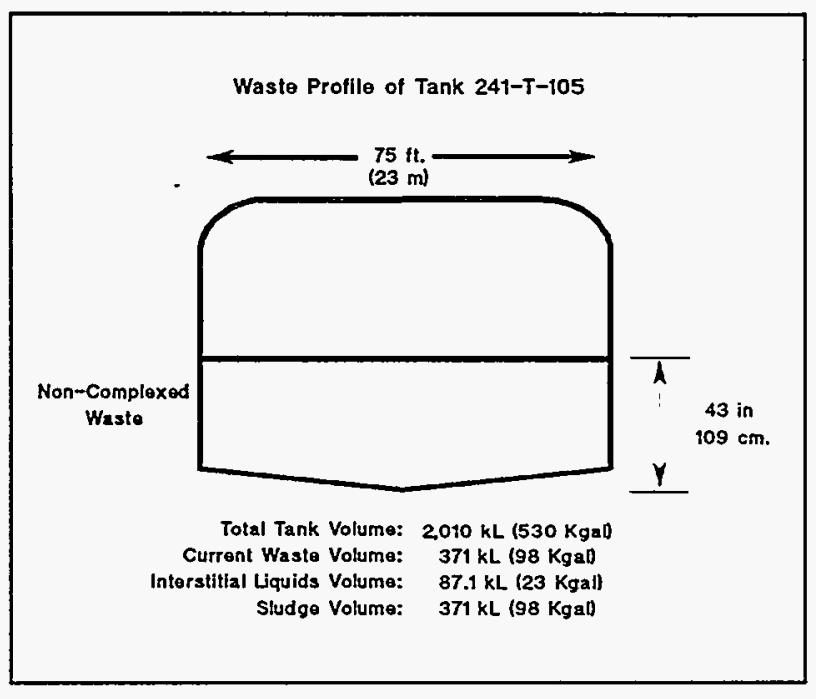
currently contains $371,000 \mathrm{~L}(98,000$ gal) of non-complexed waste, existing primarily as sludge. Approximately $87,000 \mathrm{~L}(23,000$ gal) of drainable interstitial liquid remain. The waste is heterogeneous. Tank 241-T-105 is classified as a non-Watch List tank, with no Unreviewed Safety Questions associated with it at this time. The tank was Interim Stabilized in 1987 and Intrusion Prevention was completed in 1988.

The waste in Tank 241-T-105 is comprised of precipitated salts, some of which contain traces of radioactive isotopes. The most prevalent analytes include aluminum, iron, silicon, manganese, sodium, uranium, nitrate, nitrite, and sulfate. The water digested sample results demonstrated that cadmium, chromium, lead, mercury, selenium, and silver concentrations were greater than their Toxicity Characteristic regulatory thresholds. The major radionuclide constituents are ${ }^{90} \mathrm{Sr}$ and ${ }^{137} \mathrm{Cs}$. The waste is $74.1 \%$ solids by weight. Comparisons to established limits of concern for selected analytes can be made by referring to the Tank Characterization Reference Guide (De Lorenzo et al., 1994).

The results of the analyses have been compared to the dangerous waste codes in the Washington Dangerous Waste Regulations (Ecology, 1991). This assessment was conducted by comparing tank analyses against dangerous waste characteristics ("D" waste codes) and against state waste codes. It did not include checking tank analyses against "U", "P", "F", or "K" waste codes since application of these codes is dependent on the source of the waste and not on particular constituent concentrations. The results indicate that the waste in this tank is adequately described in the Dangerous Waste Permit Application for the Single-Shell Tank System; this permit is discussed in the Tank Characterization Reference Guide (De Lorenzo et al., 1994). 


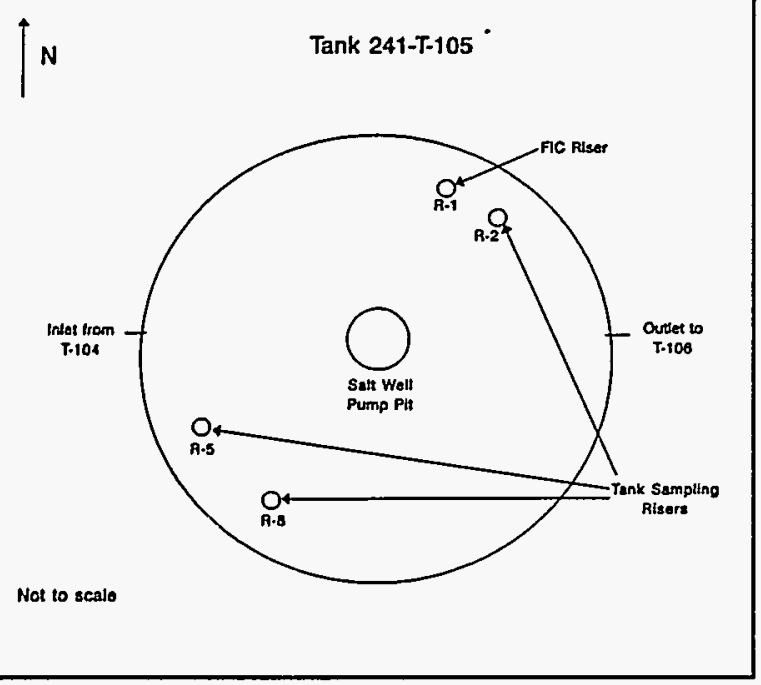

\section{Tank 241-T-105}

Tank Description

Type:

Single-Shell

Constructed:

In-Service:

1944

July 1946

Out of Service:

1974

Diameter:

$23 \mathrm{~m}$

(75 feet)

Usable Depth:

$4.9 \mathrm{~m}$

(16 feet)

Operating Capacity:

$2,000,000 \mathrm{~L}$

(530,000 gal)

Bottom Shape:

Dish

Hanford Coordinates:

$43,547^{\circ}$ North

$75,737^{\circ}$ West

Total Risers:

Ventilation:

Tank Status

Contents:

Total Waste Volume:

Non-complexed

Waste

$371,000 \mathrm{~L}$

$(98,000 \mathrm{gal})$

$87,000 \mathrm{~L}$

$(23,000$ gal $)$

$371,000 \mathrm{~L}$

(98,000 gal)

Out of Service

No thermocouples

Sound

Integrity Category:

Isolation Status:

Interim Stabilized:

1987

Intrusion Prevention:

\begin{tabular}{|c|c|c|}
\hline \multicolumn{3}{|c|}{$\begin{array}{c}\text { Single-Shell Tank } 241-T-105 \\
\text { Concentrations and Inventories for Critical List Analytes } \\
\text { (as of September 1994) }\end{array}$} \\
\hline Total Tank Volume & \multicolumn{2}{|c|}{$2,010,000 \mathrm{~L}(530,000 \mathrm{gal})$} \\
\hline Total Waste Volume & \multicolumn{2}{|c|}{$\begin{array}{c}371,000 \mathrm{~L}(98,000 \mathrm{gal}) \\
608,000 \mathrm{~kg}\end{array}$} \\
\hline Sludge Volume & \multicolumn{2}{|c|}{$\begin{array}{c}371,000 \mathrm{~L}(98,000 \mathrm{gal}) \\
608,000 \mathrm{~kg}\end{array}$} \\
\hline Supernatant Volume & \multicolumn{2}{|c|}{$\begin{array}{c}-0-L(-0-\text { gal }) \\
-0 . \mathrm{kg}\end{array}$} \\
\hline $\begin{array}{l}\text { Interstitial Liquid } \\
\text { Volume }\end{array}$ & \multicolumn{2}{|c|}{$\begin{array}{c}87,100 \perp(23,000 \text { gal }) \\
117,500 \mathrm{~kg}\end{array}$} \\
\hline \multicolumn{3}{|l|}{ Physical Properties } \\
\hline Density & \multicolumn{2}{|l|}{$1.64 \mathrm{~g} / \mathrm{ml}$} \\
\hline Percent Solids & \multicolumn{2}{|l|}{$74.1 w t \%$} \\
\hline Temperature & \multicolumn{2}{|l|}{ No thermocouples } \\
\hline $\mathrm{pH}$ & \multicolumn{2}{|l|}{10.9} \\
\hline Heat Load & \multicolumn{2}{|l|}{$1.37 \mathrm{~kW}$} \\
\hline $\begin{array}{c}\text { Chemical } \\
\text { Constituents }\end{array}$ & $\begin{array}{c}\text { Average } \\
\text { Concentration }\end{array}$ & $\begin{array}{c}\text { Bulk } \\
\text { Inventory }\end{array}$ \\
\hline Al (Aluminum) & $9.51 w t \%$ & $57,800 \mathrm{~kg}$ \\
\hline $\mathrm{Ca}$ (Calcium) & $0.37 w t \%$ & $2,230 \mathrm{~kg}$ \\
\hline Fe (Iron) & $3.31 w t \%$ & $20,100 \mathrm{~kg}$ \\
\hline Mn (Manganese) & $1.16 w t \%$ & $7,050 \mathrm{~kg}$ \\
\hline Si (Silicon) & $0.69 w t \%$ & $4,200 \mathrm{~kg}$ \\
\hline $\mathrm{Na}$ (Sodium) & $5.63 w t \%$ & $34,200 \mathrm{~kg}$ \\
\hline $\mathrm{NO}_{3}^{-}$(Nitrate) & $1.29 w t \%$ & $7,870 \mathrm{~kg}$ \\
\hline $\mathrm{NO}_{2}^{-}$(Nitrite) & $1.83 w t \%$ & $11,100 \mathrm{~kg}$ \\
\hline $\mathrm{SO}_{4}^{2-}$ (Sulfate) & $0.52 w t \%$ & $3,170 \mathrm{~kg}$ \\
\hline Total Organic Carbon & $0.41 w t \%$ & $2,510 \mathrm{~kg}$ \\
\hline Total Inorganic Carbon & $0.77 w t \%$ & $4,660 \mathrm{~kg}$ \\
\hline \multicolumn{3}{|l|}{ Radionuclides } \\
\hline Total Plutonium & $0.139 \mu \mathrm{Ci} / \mathrm{L}$ & $84.5 \mathrm{Ci}$ \\
\hline Total Uranium & $0.91 w t \%$ & $5,550 \mathrm{~kg}$ \\
\hline${ }^{137} \mathrm{Cs}$ & $55.6 \mu \mathrm{Ci} / \mathrm{L}$ & $33,800 \mathrm{Ci}$ \\
\hline${ }^{90} \mathrm{Sr}$ & $281 \mu \mathrm{Ci} / \mathrm{L}$ & $171,000 \mathrm{Ci}$ \\
\hline Total Alpha & $0.278 \mu \mathrm{Ci} / \mathrm{L}$ & $169 \mathrm{Ci}$ \\
\hline Total Beta & $866 \mu \mathrm{Ci} / \mathrm{L}$ & $527,000 \mathrm{Ci}$ \\
\hline
\end{tabular}




\section{CONTENTS}

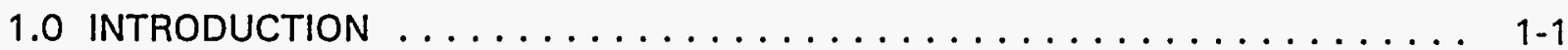

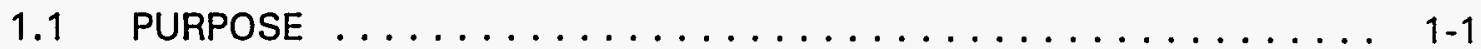

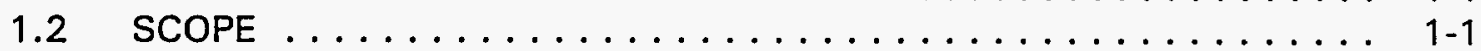

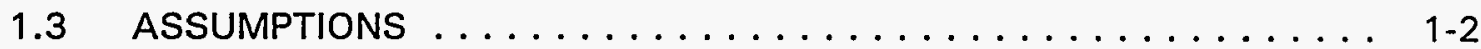

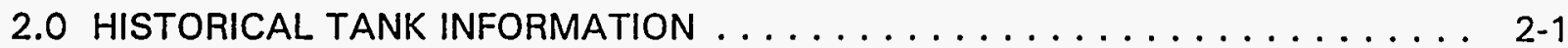

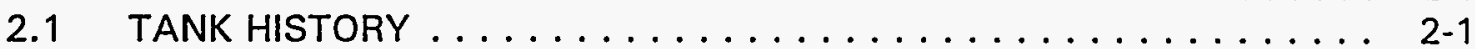

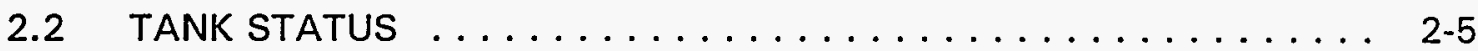

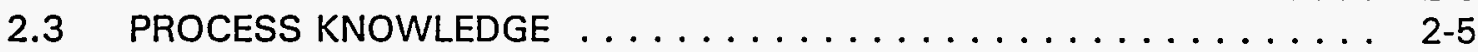

2.4 HISTORICAL ESTIMATION OF THE CONTENTS OF TANK 241-T-105 2-8 2.4.1 Process History Estimation ................ 2-8

2.4.2 Historical Sampling Estimation .............. 2-10

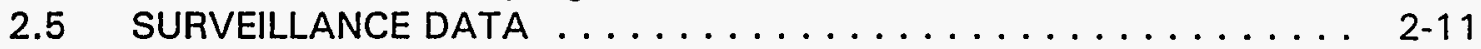

2.5.1 Surface Level Readings . . . . . . . . . . . . . 2-11

2.5.2 Internal Tank Temperatures ................ 2-11

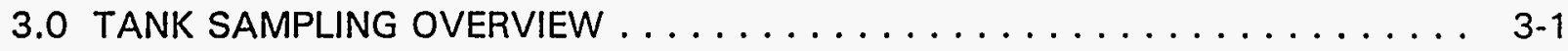

3.1 DESCRIPTION OF SAMPLING EVENT $\ldots \ldots \ldots \ldots \ldots \ldots \ldots \ldots$

3.2 SAMPLE NUMBERS AND REQUESTED ANALYSES $\ldots \ldots \ldots \ldots \ldots$ 3-1

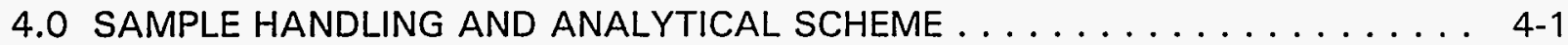

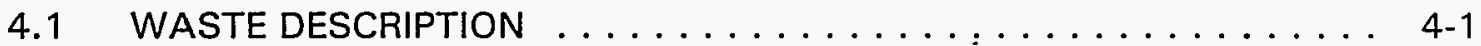

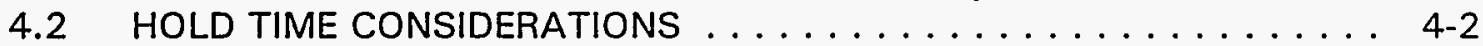

4.2.1 WHC - 222-S Laboratory . . . . . . . . . . . . . . 4 4-2

4.2.2 PNL - 325 Laboratory . . . . . . . . . . . . . . 4-2

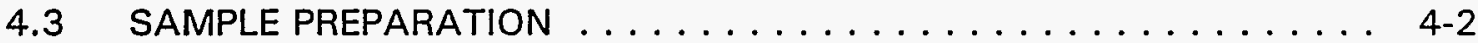

4.4 ANALYTICAL METHODS . . . . . . . . . . . . . . . . 4-2

4.4.1 Chemical and Radionuclide Analyses Quality Control . . . . . . 4-4

4.5 MODULE SPECIFIC ANALYSES $\ldots \ldots \ldots \ldots \ldots \ldots \ldots \ldots \ldots$

5.0 ANALYTICAL RESULTS AND WASTE INVENTORY $\ldots \ldots \ldots \ldots \ldots \ldots \ldots$. . . . . .

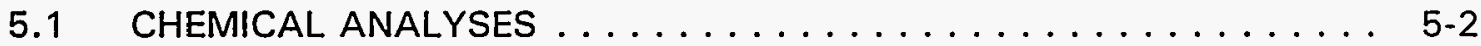

5.1 .1 Elemental Constituents . . . . . . . . . . . . . 5-2

5.1 .2 Anions ...................... 5-2

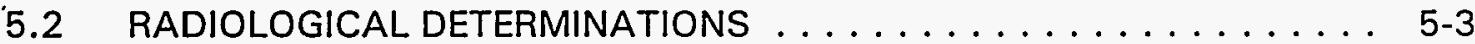

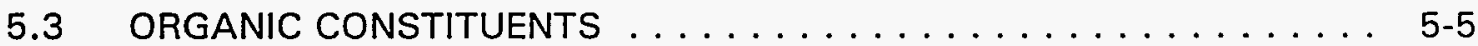

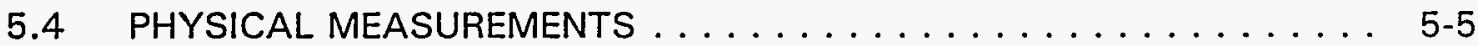

5.4.1 Density and Percent Solids ... . . . . . . . . . . . 5 5-5

5.4 .2 Particle Size . . . . . . . . . . . . . . . . . . . 5-5

5.4 .3 Rheology ......................... 5-6

5.4 .4 Energetics ....................... 5-7

5.5 DATA PRESENTATION .................... $5-7$ 
CONTENTS (continued)

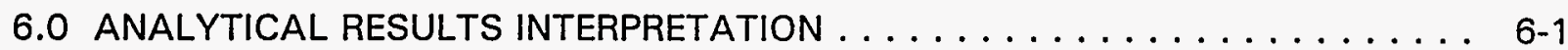

6.1 TANK WASTE PROFILE $\ldots \ldots \ldots \ldots \ldots \ldots \ldots \ldots \ldots \ldots \ldots . \ldots \ldots . \ldots \ldots$

6.2 WASTE SUMMARY AND CONDITIONS $\ldots \ldots \ldots \ldots \ldots \ldots \ldots 6-1$

6.2.1 Tank Homogeneity Observations $\ldots \ldots \ldots \ldots \ldots \ldots \ldots .6 .6 .1$

6.2 .2 Projected Tank Heat Load $\ldots \ldots \ldots \ldots \ldots \ldots \ldots \ldots \ldots$. . . . . . . . . .

6.3 PROGRAM ELEMENT SPECIFIC ANALYSES $\ldots \ldots \ldots \ldots \ldots \ldots .6 .4$

7.0 STATISTICAL INTERPRETATION $\ldots \ldots \ldots \ldots \ldots \ldots \ldots \ldots \ldots \ldots \ldots \ldots$ 7-1

7.1 MASS AND CHARGE BALANCE $\ldots \ldots \ldots \ldots \ldots \ldots \ldots \ldots \ldots 7-1$

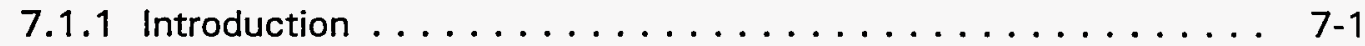

7.1 .2 Calculations and Discussion $\ldots \ldots \ldots \ldots \ldots \ldots \ldots \ldots$ 7-1

7.2 STATISTICAL ANALYSIS $\ldots \ldots \ldots \ldots \ldots \ldots \ldots \ldots \ldots \ldots$

7.3 ANALYTICAL ERROR ESTIMATION $\ldots \ldots \ldots \ldots \ldots \ldots \ldots \ldots$ 7-6

7.3.1 Systematic Analytical Error $\ldots \ldots \ldots \ldots \ldots \ldots \ldots \ldots$ 7.6

7.3.2 Random Analytical Error $\ldots \ldots \ldots \ldots \ldots \ldots \ldots \ldots$. $7-8$

7.4 DATA VALIDATION FINDINGS $\ldots \ldots \ldots \ldots \ldots \ldots \ldots \ldots \ldots .7 .9 \ldots$

8.0 RECOMMENDATIONS $\ldots \ldots \ldots \ldots \ldots \ldots \ldots \ldots \ldots \ldots \ldots \ldots \ldots \ldots \ldots$ 8-1

8.1 SAFETY ISSUES $\ldots \ldots \ldots \ldots \ldots \ldots \ldots \ldots \ldots \ldots \ldots$ 8-1

8.2 FURTHER CHARACTERIZATION NEEDS AND TANK ACTIVITIES ..... 8-1

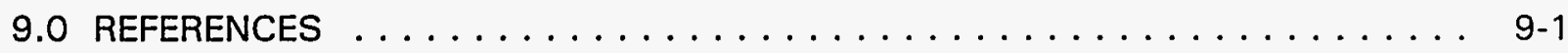

APPENDIX A ANALYTICAL RESULTS $\ldots \ldots \ldots \ldots \ldots \ldots \ldots \ldots \ldots \ldots \ldots \ldots \ldots \ldots$

APPENDIX B MASS/CHARGE BALANCE $\ldots \ldots \ldots \ldots \ldots \ldots \ldots \ldots$ B-i

\section{LIST OF FIGURES}

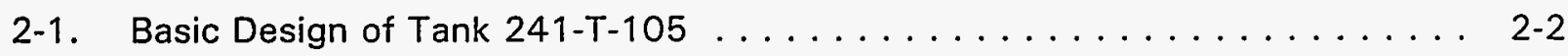

2-2. Riser Configuration for Tank 241-T-105 ............... 2-3

2-3. Location of the 241-T Tank Farm ................ 2-4

2-4. Waste Volume History of Tank $241-\mathrm{T}-105 \ldots \ldots \ldots \ldots \ldots \ldots \ldots \ldots . .2-7$

2-5. Tank 241-T-105 Historical Temperature Data $\ldots \ldots \ldots \ldots \ldots \ldots . . .2-12$

6-1. Waste Profile of Tank 241-T-105 .................. 6-2 


\section{LIST OF TABLES}

2-1. Estimated Cumulative Volume of Waste Received by Tank 241-T-105 . . . . 2-8

2-2. Solids Volumes Used for Process History Estimation of the Contents of Tank 241-T-105 ................................... 2-9

2-3. Process History Model Estimate of Tank 241-T-105 Compared to TRAC (Jungfleisch, 1984) and 1974 Sampling (Wheeler, 1974) Estimates . . . . . 2-10

3-1. Tank 241-T-105 Șample Numbers And Locations . . . . . . . . . . . . 3-2

3-2. Tank 241-T-105 Lab Tracking Numbers . . . . . . . . . . . . . 3-2

3-3. Tank -T-Samples and Requested Analytes . . . . . . . . . . . . 3-3

3-4. Standard Abbreviations Describing Analytical Methods . . . . . . . . . . . . 3-4

4-1. Inorganic and Radiochemical Analytical Methods . . . . . . . . . . 4-3

4-2. Physical and Rheological Analytical Methods . . . . . . . . . . . . . 4-4

5-1. Analytical Data Presentation Tables ................... 5-1

5-2. Comparison of Analytical and Historical Data for Elemental Constituents . . . 5-2

5-3. Comparison of Analytical and Historical Results for Tank 241-T-105 Anions . . 5-3

5-4. Comparison of Analytical and Historical Isotopic Results . . . . . . . . . . 5-3

5-4a. Activity Due to Alpha Radiation . . . . . . . . . . . . . $5-4$

5-4b. Activity Due to Beta Radiation . . . . . . . . . . . . . . . 5-4

5-5. Tank 241-T-105 Physical Properties . . . . . . . . . . . . . . 5-6

5-6. The Power Law Parameters for Segment 1, 1:1 dilution . . . . . . . . . . 5-7

5-7. Tank Characterization Report Data in Single-Shell Tank 241-T-105 . . . . . 5-8

6-1. Waste Characteristics Comparison .................. 6-3

6-2. Tank 241-T-105 Projected Heat Load . . . . . . . . . . . . . . 6-3

6-3. Applicability of Characterization Information to the Data Needs of the TWRS Program Elements ....................... $6-4$ 
WHC-SD-WM-ER-369 REV O

\section{LIST OF TABLES (continued)}

7-1. Assumed Species if Different than Analyte $\ldots \ldots \ldots \ldots \ldots \ldots \ldots$. . . . . .

7-2. Tank 241-T-105 Mass and Charge Balance . . . . . . . . . . . . . 7-2

7-3. Variance Component Estimates $\ldots \ldots \ldots \ldots \ldots \ldots \ldots \ldots$

7-4. Measurement Error Estimates $\ldots \ldots \ldots \ldots \ldots \ldots \ldots \ldots$ 


\section{LIST OF TERMS}

$\begin{array}{ll}\text { BL } & \text { B Plant low-level } \\ \text { DNFSB } & \text { Defense Nuclear Facilities Safety Board } \\ \text { DOE } & \text { U. S. Department of Energy } \\ \text { DW } & \text { decontamination waste } \\ \text { EPA } & \text { U. S. Environmental Protection Agency } \\ \text { FIC } & \text { Food Instrument Corporation } \\ \text { HLO } & \text { Hanford laboratory operations } \\ \text { IX } & \text { ion exchange } \\ \text { MDL } & \text { method detection limit } \\ \text { PNL } & \text { Pacific Northwest Laboratory } \\ \text { RCRA } & \text { Resource Conservation and Recovery Act } \\ \text { REDOX } & \text { Reduction-Oxidation } \\ \text { RPD } & \text { relative percent difference } \\ \text { SpG } & \text { specific gravity } \\ \text { TRAC } & \text { Track Radioactive Constituents } \\ \text { TWRS } & \text { Tank Waste Remediation System } \\ \text { WHC } & \text { Westinghouse Hanford Company } \\ \text { 1C } & \text { first-cycle decontamination } \\ \text { 2C } & \text { second-cycle decontamination }\end{array}$




\subsection{INTRODUCTION}

In March and May, 1993, Single-Shell Tank 241-T-105 was sampled to contribute toward meeting Interim Milestone M-10-07 of the Hanford Federal Facility Agreement and Consent Order (Tri-Party Agreement) (Ecology, EPA, and DOE, 1993). Characterization of the waste from this sampling effort will assist in fulfilling Milestone M-44-05 of the Tri-Party Agreement. Sampling was also performed to determine proper handling of the waste, to address corrosivity and compatibility issues, and to comply with requirements of the Washington Administrative Code (Ecology, 1991). This Tank Characterization Report presents an overview of that tank sampling and analysis effort, and contains observations regarding waste characteristics. It also addresses expected concentration and inventory data for the waste contents based on this latest sampling data and background tank information. Finally, this report makes recommendations and conclusions regarding the present status, operational safety, condition of the tank, and any further characterization needs.

\subsection{PURPOSE}

The purpose of this report is to describe and characterize the waste in Single-Shell Tank 241-T-105 (hereafter, Tank 241-T-105) based on information given from various sources. This report summarizes the available information regarding the waste in Tank $241-\mathrm{T}$ 105 , and using the historical information to place the analytical data in context, arranges this information in a useful format for making management and technical decisions concerning this waste tank.

Specific objectives reached by the sampling and characterization of the waste in Tank 241-T-105 are to:

- Contribute toward the fulfillment of the Hanford Federal Facility Agreement and Consent Order (Tri-Party Agreement) Milestone M-44-05 concerning the characterization of Hanford Site high-level radioactive waste tanks (Ecology, EPA, and DOE, 1993).

- Complete safety screening of the contents of Tank 241-T-105 to meet characterization requirements of the Defense Nuclear Facilities Safety Board (DNFSB) Recommendation 93-5 (Conway, 1993).

- Provide tank waste characterization to the Tank Waste Remediation System (TWRS) Program Elements in accordance with the TWRS Tank Waste Analysis Plan (Bell, 1994).

\subsection{SCOPE}

This report first presents a broad description of the tank and its historical background. This allows a detailed estimation of the contents of Tank 241-T-105 based on historical process information and detailed transaction records. Next, the results of the sampling and analysis effort are summarized and interpreted both qualitatively and statistically. The 
information obtained from historical sources is then compared with the actual waste measurements to arrive at final waste inventory and concentration estimates. Finally, conclusions and recommendations are given based on the current waste inventory and tank status.

\subsection{ASSUMPTIONS}

The concentration and inventory estimates derived for this report are considered by the authors and by the Westinghouse Hanford Company Characterization Program to be the most accurate, defensible, technically valid, and contemporary data concerning Tank 241-T-105. This Tank Characterization Report incorporates all available previous sampling, characterization, and transfer data concerning Tank 241-T-105. In addition, estimates of the current tank contents based on process knowledge and waste transaction records provide important cross-checks and corroboration to the inventory estimates derived from recent analytical data. Given that the analytical data are valid and defensible, this report is the definitive characterization of the contents of Tank 241-T-105.

The term "analytical results" is used in this report to denote sample results from the most recent sampling event. Characterization data from these samples are used as the basis for the analytical section of this report, Section 5.0. The historical characterization of this tank, Section 2.4, is based on available analytical and process information prior to the 1993 sampling.

Tank 241-T-105 no longer receives waste; it has been interim stabilized and work has been completed to minimize the addition of liquids (Hanlon, 1994). The characterization of Tank 241-T-105 is considered accurate and representative of the tank contents as of the date of preparation of this report: September 1994. 


\subsection{HISTORICAL TANK INFORMATION}

The purpose of this section is to describe Tank 241-T-105 based on historical information. It is divided into five parts. A brief description and historical background of the tank comprise the first part, followed by the current tank status, a summary of the process sources that contributed to the tank waste, and an estimation of the contents of Tank 241-T105 based on historical information. The final part details the surveillance data taken on the tank.

\subsection{TANK HISTORY}

Single-Shell Tank 241-T-105 consists of a carbon steel tank within a reinforced concrete shell and dome. It has a diameter of $23 \mathrm{~m}(75 \mathrm{ft}$.), an operating depth of $4.9 \mathrm{~m}$ (16 $\mathrm{ft}$.$) , and a capacity of 2.01 \mathrm{E}+06$ liters $(530,000$ gallons) (Husa et al., 1993). The basic design of Tank 241-T-105 is shown in Figure 2-1. Instruments access Tank 241-T-105 through risers and monitor the temperature, sludge level, and other bulk tank characteristics (Fulton, 1992). The position of these risers is found in Figure 2-2.

The 241-T Tank Farm, built between 1943 and 1944, is one of the initial four tank farms to be used at the Hanford Site. It is the northernmost tank farm in the 200 West Area. Figure 2-3 details the Hanford Site's 200 West Area and the location of the 241-T Tank Farm. As Figure 2-2 shows, Tank 241-T-105 is located in the second row from the top and second column from the right of the 241-T Tank Farm.

Tank 241-T-105 is the second tank in a "cascade" connecting it to Tanks 241-T-104 and 241-T-106. A cascade was a system where several tanks were connected in series by pipes. These pipes were located at the top of the tanks' working depths. Waste was added to the first tank in a cascade and flowed to the next tank without overfilling the first tank. By using a cascade, fewer connections needed to be made during waste handling operations. This method reduced waste handling requirements, personnel exposure, and the chance of a loss of tank integrity from waste overflow: Another advantage of using the cascades was to clarify the waste. Heavier solids and insoluble constituents would precipitate primarily in the first tank (in this case Tank 241-T-104), and the clarified liquids would flow through the cascade on to the other tanks (T-105 and T-106). This practice led to rapid filling of the first tank with solids and allowed the clarified liquid from the tanks in the cascade to be discharged to cribs.

Tank 241-T-105 went into service in 1946, receiving second cycle decontamination (2C) waste (Anderson, 1990). This waste was sent directly to the tank, bypassing Tank 241T-104 and the connecting cascade (Jungfleisch, 1984a). The $2 \mathrm{C}$ waste cascaded out of Tank 241-T-105 to Tank 241-T-106. In 1948, the cascade line from Tank 241-T-104 to Tank 241T-105 was used and Tank 241-T-105 began to receive first cycle (1C) waste through this cascade (Jungfleisch, 1984a). The cascade from Tank 241-T-104 to Tank 241-T-105 was no longer used after the last additions of 1C waste from T-Plant in 1954. 
WHC-SD-WM-ER-369 REV O

Figure 2-1. Basic Design of Tank 241-T-105.

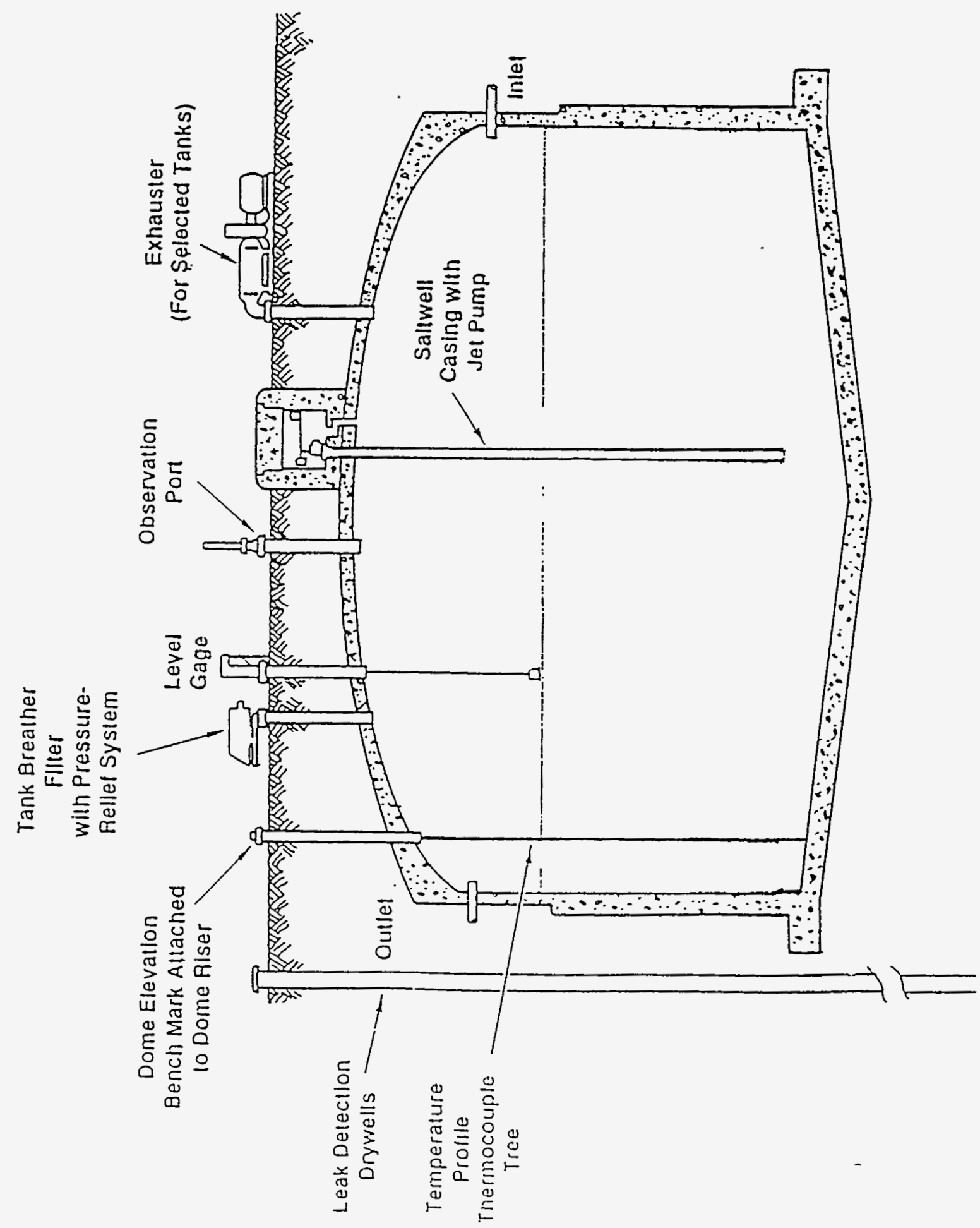


Figure 2-2. Riser Configuration for Tank 241-T-105.

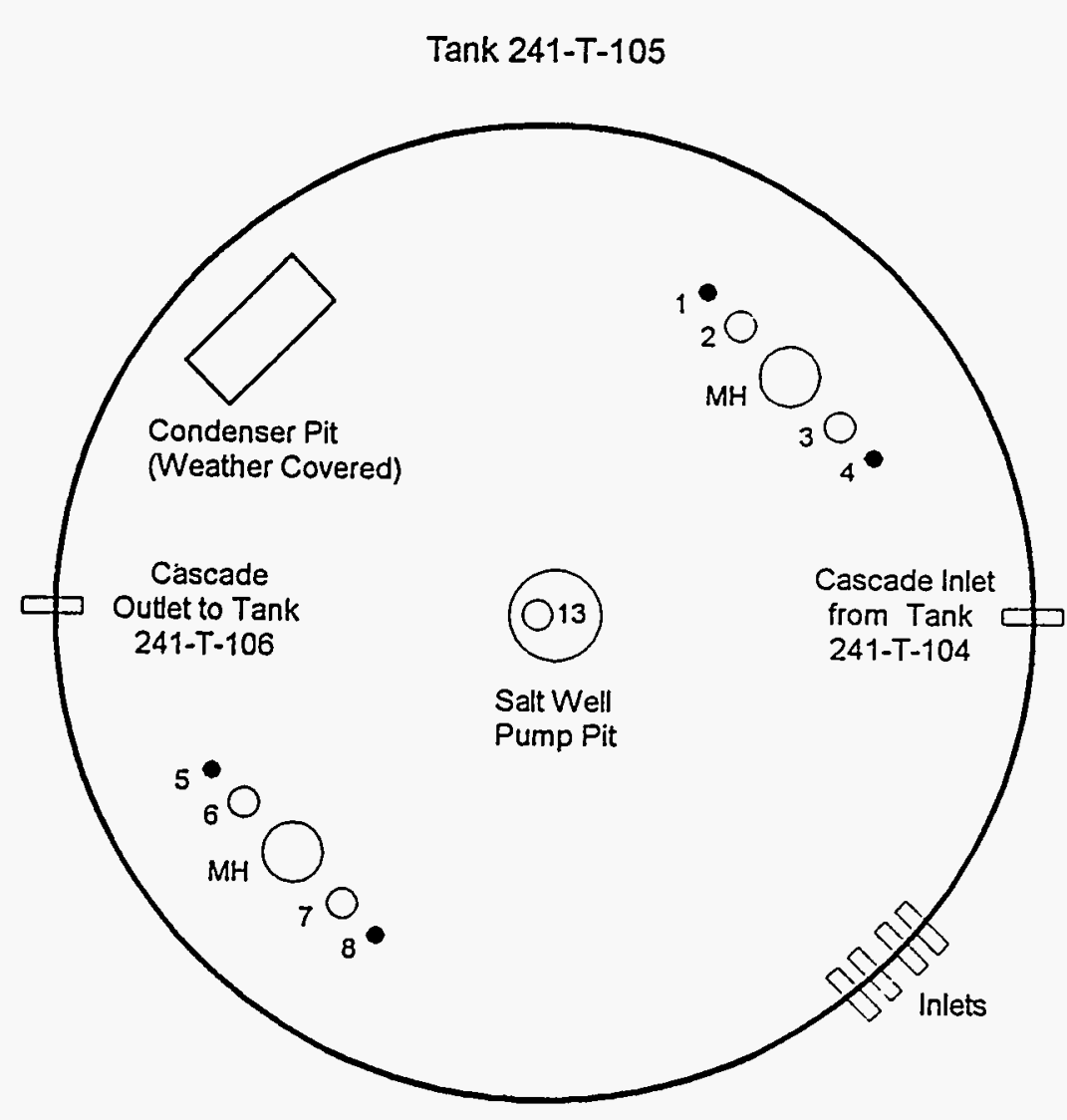

\begin{tabular}{|c|c|l|}
\hline No. & Dia. & \multicolumn{1}{|c|}{ Description and Comments } \\
\hline 1 & $4^{\prime \prime}$ & FIC Level Gauge \\
\hline 2 & $12^{\prime \prime}$ & Observation Port \\
\hline 3 & $12^{\prime \prime}$ & Flange \\
\hline 4 & $4^{\prime \prime}$ & Thermocouple Probe \\
\hline 5 & $4^{\prime \prime}$ & Breather Filter \\
\hline 6 & $12^{\prime \prime}$ & Flange \\
\hline 7 & $12^{\prime \prime}$ & Flange \\
\hline 8 & $4^{\prime \prime}$ & Flange \\
\hline 13 & $12^{\prime \prime}$ & Salwell Screen \\
\hline
\end{tabular}

MH 42" Manhole in dome, no riser to surface

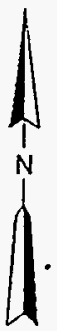

241-T Tank Farm

(Showing Cascade Connections)
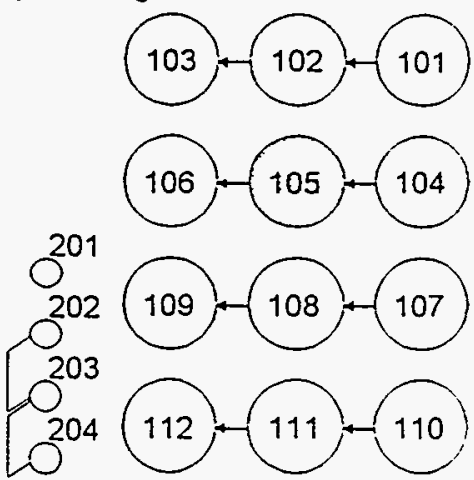

Sources: Fulton, 1992

Vitro Eng. Corp., 1979

Hanford Eng. Works, 1944 
Figure 2-3. Location of the 241-T Tank Farm.

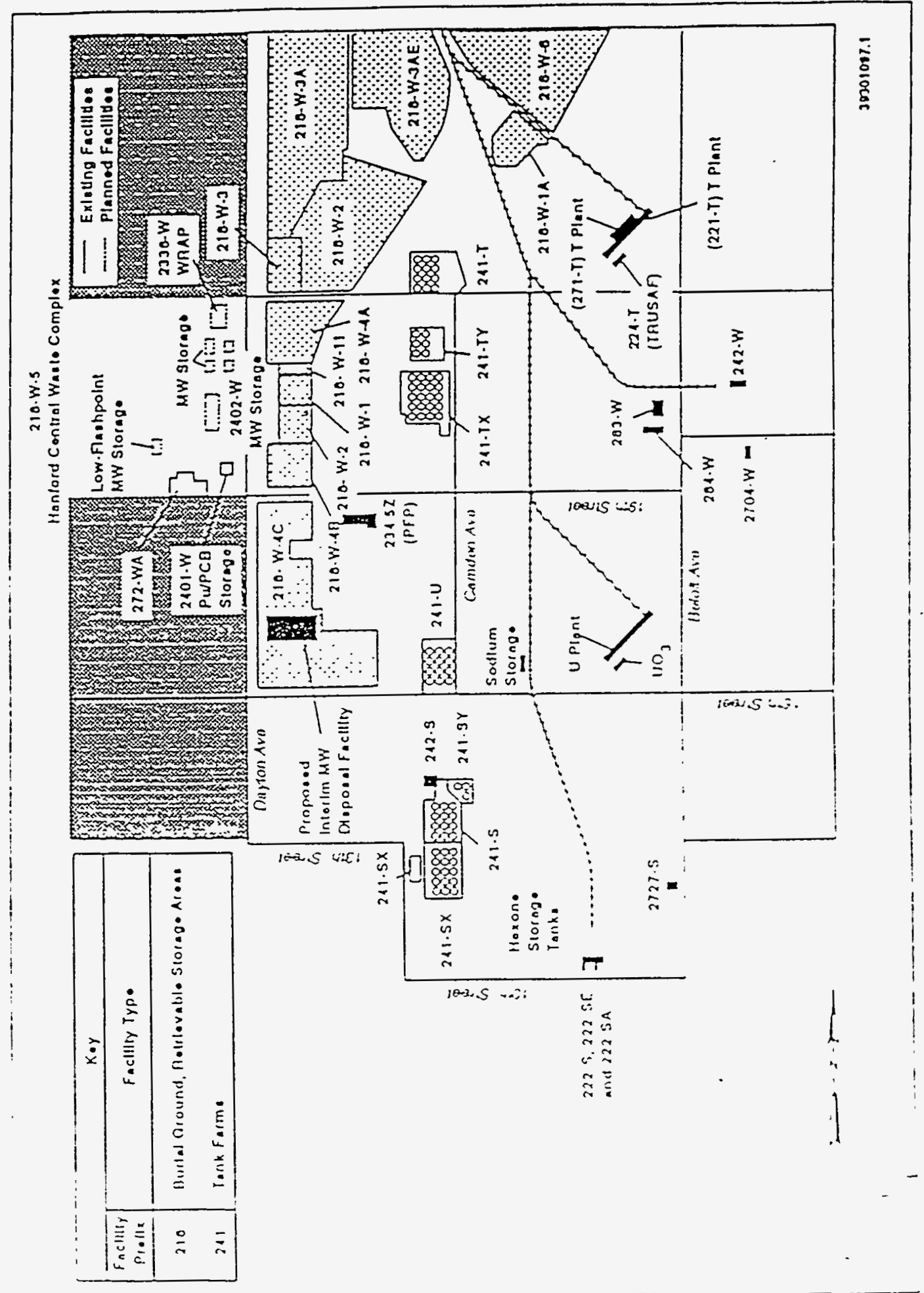


As part of an overall tank farms effort to increase surveillance, two dry wells were drilled around Tank 241-T-105 in 1973, and another dry well was drilled in 1975. All of these dry wells have registered high radiation activity; however, this activity has been attributed to an estimated 435,000 liter (115,000 gallon) leak from Tank 241-T-106 (Welty, 1988).

During its operational lifetime, liquids from Tank 241-T-105 were discharged to the cribs, to various tanks, and to the REDOX Evaporator. Tank 241-T-105 was removed from service in 1976. Salt well pumping commenced in the same year and continued into the following year. A new salt well was installed in the tank from 1977 to 1978 . Tank 241-T105 was primary stabilized in 1980 (Anderson, 1990). This involved the removal of liquid above the solids (other than isolated surface pockets) by salt well pumping. The tank was designated Interim Stabilized in 1987. This was an administrative change and did not require any physical modifications to the tank. Intrusion Prevention on Tank 241-T-105 was completed in 1988. Intrusion Prevention is the administrative designation reflecting the completion of physical modifications to minimize the addition of liquids into the tank.

\subsection{TANK STATUS}

Tank 241-T-105 currently contains 371,000 liters $(98,000$ gallons) of waste. This waste is sludge with an estimated 87,000 liters $(23,000$ gallons) of interstitial liquid (Hanlon, 19941. No current temperature data are available because there is no thermocouple tree in this tank. Waste levels and tank temperatures are further discussed in Section 2.5. Tank 241-T-105 is listed as a low heat load tank (Hanlon, 1994), and is passively vented to the atmosphere through a breather filter (Bergmann, 1991). With the exception of temperature readings, monitoring systems are currently in compliance with established standards (Hanlon, 19941.

The current designation of the tank contents is non-complexed waste. This is a general term used to describe waste that does not have a high content of organic carbon and/or carbon-bearing complexants. Tank 241-T-105 is not a Watch List tank, nor does it have Unreviewed Safety Questions associated with it. The integrity of Tank 241-T-105 is sound. The tank has been Interim Stabilized, and it has undergone Intrusion Prevention (Hanlon, 1994).

\subsection{PROCESS KNOWLEDGE}

The first waste type to be introduced into Tank 241-T-105 was second cycle (2C) waste in 1946. This waste consisted of effluent remaining after precipitation of plutonium product in the second decontamination cycle of the $\mathrm{BiPO}_{4}$ process at T Plant. The $2 \mathrm{C}$ waste filled the tank and then cascaded to Tank 241-T-106. Since Tank 241-T-105 received waste directly from T-Plant, $2 \mathrm{C}$ solids are expected to have been deposited in the lower portion of the tank. In 1948, much of the $2 \mathrm{C}$ supernate in Tank $241-\mathrm{T}-105$ was sent to the cribs.

From 1948 to 1949 , Tank 241-T-105 received first cycle (1C) waste cascaded into the tank from Tank 241-T-104. Produced in the $\mathrm{BiPO}_{4}$ process at $\mathrm{T}$ plant, this $1 \mathrm{C}$ waste consisted of byproducts co-precipitated from a plutonium-containing solution. Coating waste from the removal of aluminum fuel element cladding was also added, and comprised about $24 \%$ of the waste stream. This $1 \mathrm{C}$ waste is characterized by a relatively high concentration of bismuth and aluminum. 
In 1954, the supernatant in Tank 241-T-105 was pumped out and sent to the cribs. The cascade system was not used after this year. The tank began receiving coating waste at the beginning of 1955 and was full by the end of 1956. Coating waste was produced at the REDOX Plant from the dissolution of aluminum fuel cladding. The aluminum cladding was dissolved in a sodium nitrate-sodium hydroxide solution. As can be expected, coating waste has a very high concentration of aluminum.

The waste was allowed to settle for about 10 years until 1967 when the supernate, which made up the bulk of the tank's volume, was transferred out of the tank. In the same year, Tank 241-T-105 was filled with Hanford laboratory operations waste. This dilute waste was generated by laboratories in the 300 Area. Also in 1967 and 1968, much of the contents of Tank 241-T-105 were sent to the REDOX Evaporator.

In 1968 and 1969, Tank 241-T-105 received decontamination waste (DW). This is wash solution from equipment decontamination efforts at T-Plant. It is mainly a dilute sodium nitrite solution, averaging $0.024 \mathrm{M}$ sodium nitrite. Transfers from other single-shell tanks of liquid waste mixtures containing B-Plant low level (BL) and ion exchange (IX) wastes filled Tank 241-T-105 in 1973. Supernate, consisting of most of the tank's volume, was transferred out of the tank and BL and IX refilled the tank in the same year. B-Plant low level waste originated from the fractionization plant. Ion exchange waste was a product of the cesium recovery process at B-Plant. The waste types discussed in this paragraph are not expected to contribute substantially to the tank's solids content, and, in fact, may have dissolved some of the pre-existing salts.

In 1974, most of the supernate was again pumped out of Tank 241-T-105. Any remaining supernate was removed in the next few years. A graphical waste volume history of Tank 241-T-105 is included as Figure 2-4. Table 2-1 presents the estimated cumulative volume of each of the waste types received by Tank 241-T-105. 
Figure 2-4. Waste Volume History of Tank 241-T-105.




Table 2-1. Estimated Cumulative Volume of Waste Received by Tank 241-T-105 (Jungfleisch, 1984; Anderson, 1990).

\begin{tabular}{|c|c|}
\hline Waste Type & Estimated Volume* \\
\hline 2C & $3,994,000 \mathrm{~L}(1,055.000$ gal $)$ \\
\hline $1 C^{* *}$ & $7,011,000 \mathrm{~L}(1,852,000$ gal $)$ \\
\hline CWR & $1,261,000 \mathrm{~L}(333,000$ gal $)$ \\
\hline HLO & $1,499,000 \mathrm{~L}(396,000$ gal $)$ \\
\hline DW & $1,230,000 \mathrm{~L}(325,000$ gal $)$ \\
\hline SUP & $3,229,000 \mathrm{~L}(853,000$ gal $)$ \\
\hline
\end{tabular}

Estimated total volume of waste is greater than $2,006,000$

Liters $(530,000$ gallons) because waste was routinely pumped from Tank 241-T-105 and also cascaded to Tank 241-T-106.

* * Tank 241-T-105 received 1C waste from Tank 241-T-104 as the second tank in a cascade.

2C Second cycle decontamination waste from the bismuth phosphate process at T-Plant.

1C First cycle decontamination waste from the bismuth phosphate process at T-Plant.

CWR Coating waste from the dissolution of aluminum fuel cladding at REDOX.

HLO Hanford laboratory waste from 300 Area laboratories.

DW decontamination waste from T-Plant.

SUP Supernate transferred from other single-shell tanks; includes BPlant low-level and ion exchange wastes.

\subsection{HISTORICAL ESTIMATION OF THE CONTENTS OF TANK 241-T-105}

A preliminary estimate of the waste constituents in Tank 241-T-105 can be developed by reviewing historical data for the tank. This section uses the process history of the tank and past sampling efforts to develop an estimation of the contents of Tank 241-T-105.

\subsubsection{Process History Estimation}

A model of the constituents of Tank 241-T-105 has been developed for this document by reviewing historical transfer records and level measurements. This model estimates the solids volume of each type of waste in the tank and then uses the compositions of these wastes to develop an overall estimate of several constituents. The development of this model is described in Section 2.4.1.1. Another estimate based on the tank's process history is the TRAC (Track Radionuclide Components) database program (Jungfleisch, 1984b). Both estimates are presented in Table 2-3. 
2.4.1.1 Assumptions of the Process History Model. Section 2.3 describes the process history of Tank 241-T-105. Examination of this section shows that a layer of second cycle (2C) decontamination waste is expected to fill the bottom of the tank. First cycle (1C) decontamination waste cascaded into Tank 241-T-105 from Tank 241-T-104 makes up another layer. After May 1951, coating waste from T-Plant became a component of 1C waste. The $1 \mathrm{C}$ waste in Tank 241-T-105 consists of waste from before and after May 1951, thus the $1 \mathrm{C}$ waste is actually two layers of different types of $1 \mathrm{C}$ waste. Sitting above the $1 \mathrm{C}$ waste is a layer of coating waste solids from the REDOX plant. The other waste types that were added to the tank did not have a significant amount of solids. It follows that these dilute wastes were transferred out of the tank in a series of supernate transfers. For this reason, the process history model assumes that $2 \mathrm{C}, 1 \mathrm{C}$, and coating waste make up the significant solids content in the tank.

Fill histories (Jungfleisch, 1984a; Anderson, 1990) were used to develop estimates of the volumes of specific waste types in the tank. These sources provided estimates of the total amounts of $1 \mathrm{C}, 2 \mathrm{C}$, and coating waste that entered the tank. The solids volumes of these waste types were taken from Hanford Defined Wastes: Chemical and Radionuclide Compositions (Agnew, 1994). The $1 \mathrm{C}$ and $2 \mathrm{C}$ wastes were involved in cascades. It was assumed that a tank retained $90 \%$ of the solids from the waste cascaded through the tank.

Calculation of the total volume of solids in the tank yielded a value of $5.05 \mathrm{E}+05$ liters. A $26.5 \%$ volume reduction is required to arrive at the current volume of $3.71 \mathrm{E}+05$ liters. This waste volume decrease and the resulting values of solids volume of the different types of waste in the tank is shown in Table 2-2. There is no criteria to determine whether a particular waste type retained more or less of its solids content in the tank. The $26.5 \%$ waste volume reduction was thus applied to all the solid wastes in the tank. Such a decrease in volume can be explained by settling of wastes and by salt well pumping.

Table 2-2. Solids Volumes Used for Process History Estimation of the Contents of Tank 241-T-105.

\begin{tabular}{|l|c|c|c|c|c|}
\cline { 2 - 6 } \multicolumn{1}{c|}{} & $2 \mathrm{C}$ & $1 \mathrm{C}^{\prime} 44-^{\prime} 51$ & $1 \mathrm{C}^{\prime} 51-^{\prime} 56$ & CWR & Total \\
\hline 1974 Volume (L) & $2.45 \mathrm{E}+05$ & 75,700 & 82,100 & $1.02 \mathrm{E}+05$ & $5.05 \mathrm{E}+05$ \\
\hline $\begin{array}{l}\text { Adjusted for 1994 } \\
\text { Volume* (L) }\end{array}$ & $1.80 \mathrm{E}+05$ & 55,700 & 60,400 & 75,100 & $3.71 \mathrm{E}+05$ \\
\hline Percent of Volume & 48.5 & 15.0 & 16.3 & 20.3 & 100.0 \\
\hline
\end{tabular}

2C Second cycle decontamination waste from T-Plant.

1C '44-'51 First cycle decontamination waste from T-Plant produced from 1944 to May 1951.

$1 \mathrm{C}$ '52-'56 First cycle decontamination waste from T-Plant produced from May 1951 to 1956 . Coating waste was added to $1 \mathrm{C}$ waste after May 1951.

CWR Coating waste from dissolution of aluminum fuel cladding at REDOX.

* A $26.5 \%$ volume reduction was used to bring the total waste volume into agreement with 1994 measurements. 


\subsubsection{Historical Sampling Estimation}

Analytical data is available for a sampling of Tank 241-T-105 in 1974. Sample T-4297 was described as dark amber in color (Wheeler, 1974). Since Tank 241-T-105 was taken out of service in 1974, there have been no additions and only small transfers out of the tank. It is thus reasonable to assume that this sampling should reflect current conditions in the tank.

Concentration data from the sample analysis was combined with the tank's total volume in 1974 to generate an estimated total inventory of the tank's constituents. This estimate is compared to TRAC and process history estimates in Table 2-3.

Table 2-3. Process History Model Estimate of Tank 241-T-105 Compared to TRAC (Jungfleisch, 1984) and 1974 Sampling (Wheeler, 1974) Estimates.

\begin{tabular}{|c|c|c|c|c|}
\hline \multicolumn{3}{|c|}{ Process History Model } & TRAC & 1974 Sample \\
\hline \multicolumn{5}{|c|}{ Physical Properties } \\
\hline Total Waste & \multicolumn{2}{|c|}{$3.71 E+05 \mathrm{~L}(98,000$ gallons $)$} & $4.32 E+05 L$ & $3.49 E+05 L$ \\
\hline Bulk Density & \multicolumn{2}{|c|}{1.30} & & 1.21 \\
\hline Void Fraction & \multicolumn{2}{|c|}{.81} & & - \\
\hline wt\% Water & \multicolumn{2}{|c|}{67.3} & & 77.1 \\
\hline \multicolumn{5}{|c|}{ Chemical Constituents } \\
\hline Analyte & $\mu \mathrm{g} / \mathrm{g}$ & $\mathrm{kg}$ & $\mathrm{kg}$ & $\mathrm{kg}$ \\
\hline $\mathrm{Na}$ & 61,300 & 29,300 & $6.9 E-03$ & 34,500 \\
\hline $\mathrm{Al}$ & 27,900 & 15,700 & 5,400 & 400 \\
\hline $\mathrm{Fe}$ & 10,400 & 4,600 & .056 & - \\
\hline $\mathrm{Cr}$ & 455 & 205 & 360 & - \\
\hline $\mathrm{Bi}$ & 16,600 & 7,400 & $4.2 E+05$ & - \\
\hline$U$ & $12,200 \mathrm{ug} / \mathrm{g}$ & $5,800 \mathrm{~kg}$ & $7,400 \mathrm{~kg}$ & - \\
\hline $\mathrm{ZrO}(\mathrm{OH})_{2}$ & 477 & 280 & 540 & - \\
\hline $\mathrm{CO}_{3}{ }^{2-}$ & 0 & 0 & 0 & 19,200 \\
\hline $\mathrm{OH}^{-}$ & 46,500 & 18,200 & $1.9 E+05$ & 700 \\
\hline $\mathrm{NO}_{3}^{-}$ & 42,600 & 17,300 & 0 & 14,200 \\
\hline $\mathrm{NO}_{2}^{-}$ & 12,900 & 4,000 & 0 & 25,600 \\
\hline $\mathrm{PO}_{4}{ }^{3-}$ & 35,300 & 16,900 & $1.9 E+05$ & 205 \\
\hline $\mathrm{SO}_{4}{ }^{2-}$ & 2,800 & 1,300 & 0.096 & 5,750 \\
\hline $\mathrm{SiO}_{3}{ }^{2-}$ & 7,800 & 11,400 & 0 & - \\
\hline$\overline{F^{-}}$ & 5,500 & 2,500 & 0 & 290 \\
\hline \multicolumn{5}{|c|}{ Radiological Constituents } \\
\hline $\mathrm{Pu}$ & $0.395 \mathrm{uCi} / \mathrm{g}$ & & $2.5 \mathrm{~kg}$ & - \\
\hline${ }^{137} \mathrm{Cs}$ & $4.44 \mathrm{uCi} / \mathrm{g}$ & $2,200 \mathrm{Ci}$ & $1.0 \mathrm{E}-12 \mathrm{Ci}$ & $39,200 \mathrm{Ci}$ \\
\hline${ }^{90} \mathrm{Sr}$ & $3.56 \mathrm{uCi} / \mathrm{g}$ & $1,800 \mathrm{Ci}$ & $6,000 \mathrm{Ci}$ & - \\
\hline
\end{tabular}




\subsection{SURVEILLANCE DATA}

\subsubsection{Surface Level Readings}

Tank 241-T-105 uses a Food Instrument Corporation automatic level gauge to measure the waste level in the tank. This gauge uses a conductivity probe which is automatically lowered until electrical contact is made with the waste surface. The measurement is then recorded on the Computer Automated Surveillance System.

Waste level measurements determined during the Interim Stabilization of Tank 241-T105 included photograph reviews for verification. The Single-Shell Tank Stabilization Record (Swaney, 1994) reports an uneven surface with a waste level of about $76 \mathrm{~cm}$ (30 inches) for Tank 241-T-105. This value does not consider the dish-shaped bottom of the tank. This dish bottom adds $30.5 \mathrm{~cm}$ (12 in.) to the total depth of the tank. The waste level of $109 \mathrm{~cm}(43$ in.) reported in Tank Farm Surveillance and Waste Status Summary Report for March 1994 (Hanlon, 1994) accounts for the dish bottom of the tank.

\subsubsection{Internal Tank Temperatures}

The last available temperature reading for Tank $241-\mathrm{T}-105$ was $23^{\circ} \mathrm{C}\left(73^{\circ} \mathrm{F}\right)$ taken in February 1981. According to the Riser Configuration Document for Single-Shell Tanks (Fulton, 1992), the thermocouple tree was cut off in 1981. It is not known why the thermocouple tree was removed.

Since Tank 241-T-105 has not received any waste since it was removed from service in 1976, it is likely that the historical temperature data is representative of current temperatures in the tank. Radiation-generated heat decreases as radioactive constituents decay over time, so historical temperatures may tend to be somewhat higher than current temperatures. Historical temperature data from 1977 to 1981 are available and presented in Figure 2-5. 
WHC-SD-WM-ER-369 REV O

Figure 2-5. Tank 241-T-105 Historical Temperature Data.

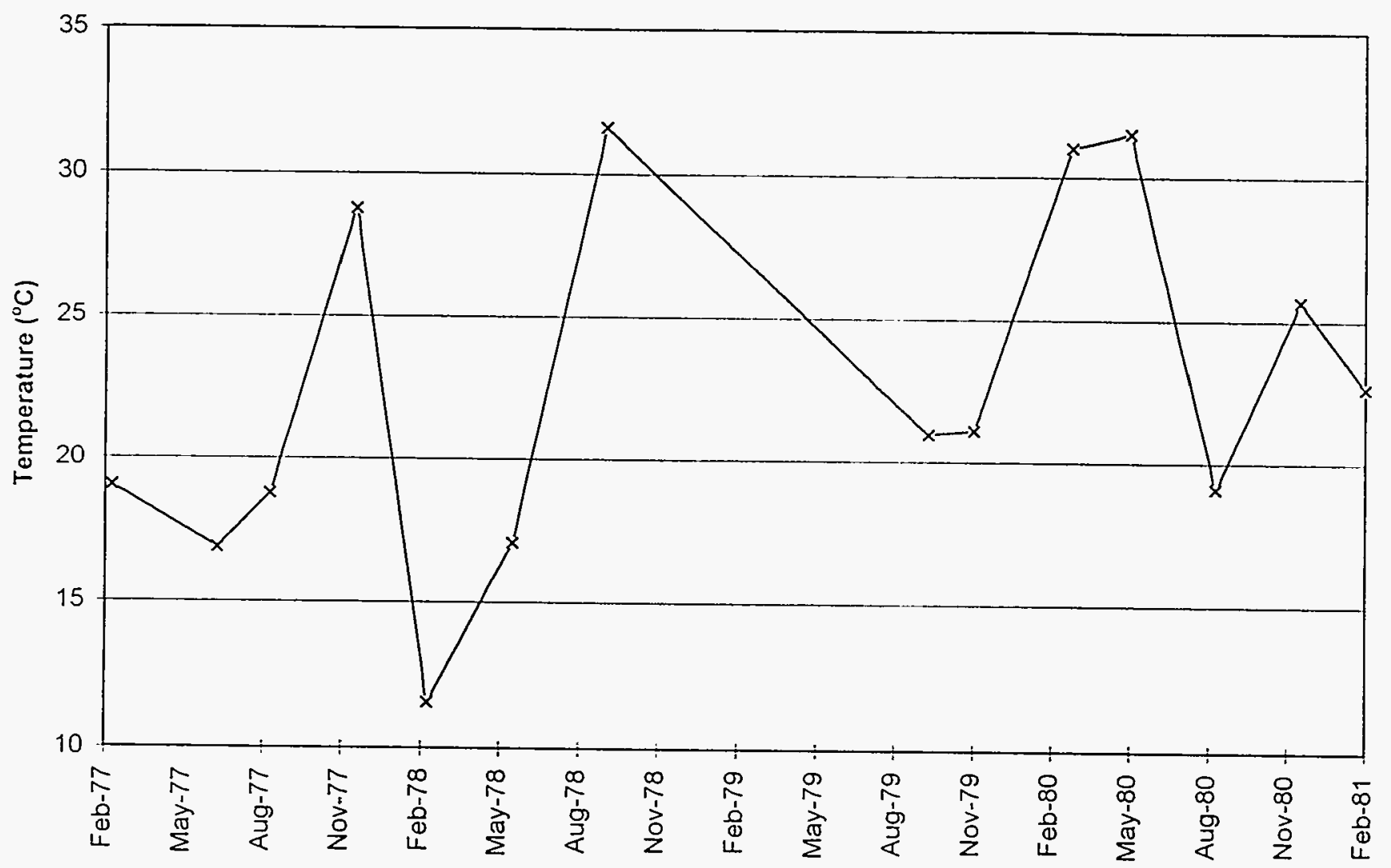




\subsection{TANK SAMPLING OVERVIEW}

The sampling of Tank 241-T-105 was part of an overall plan to characterize the wastes in all the underground storage tanks on the Hanford Site. The results of these analyses will provide support for Tank Farm Operations, and safety programs. It will also assist in the design of retrieval, pretreatment, and disposal systems and fulfill milestones contained in the Tri-Party Agreement (Bell, 1994).

This section of the characterization report contains a brief description of sampling activities, sample locations and information about additional sampling.

\subsection{DESCRIPTION OF SAMPLING EVENT}

Core 53 and 54 samples were collected on March 19 and 23, 1993 respectively, from risers 8 and 2. The field blank was collected on March 22, 1993. These cores were transported to the Westinghouse Hanford Company 222-S Laboratory for chemical analyses and to the Pacific Northwest Laboratory (PNL) 325 Laboratory for physical tests. Core 57 samples were collected on May 28, 1993 from riser number 5 in order to support the core sampling restart effort. Both segments were sent to PNL 325 Laboratory for physical tests. For a diagram of riser location, refer to Figure 2-2 (Kocher, 1993 and Giamberardini, 1993).

The core samples were obtained using a core sampling truck that has sampling equipment mounted on a rotating platform. A drill string, containing a stainless steel sampler, was pushed or rotated into the waste. The sampler was used to obtain a $48 \mathrm{~cm}(19 \mathrm{in}$.$) long$ and a $2.5 \mathrm{~cm}$ (1 in.) diameter segment of the waste. After the sampler was filled, it was extracted from the drill string and sealed within a stainless steel liner, to trap any liquid which might leak from the sampler. The liner was inserted into a lead shielded shipping cask before transferral to the laboratories. Chain-of-custody forms were completed for each segment. Table 3-1 shows a list of tank farm sample numbers and shipping sample numbers as well as the date and sampling locations. For a further description of core sampling procedures, see the Tank Characterization Reference Guide (De Lorenzo et al., 1994).

\subsection{SAMPLE NUMBERS AND REQUESTED ANALYSES}

In hot cells at each laboratory, the core samples were mechanically extruded from the samplers. Any drainable liquids were collected. Samples were then removed, homogenized or formed into composites. Results from the two homogenized subsamples were used to evaluate the homogenization procedure. See Table 3-2 for sample designations and tracking numbers. A list of samples and requested analyses is provided in Table 3-3. 
Table 3-1. Tank 241-T-105 Sample Numbers And Locations.

\begin{tabular}{|c|c|c|c|c|c|c|}
\hline Core & Riser & Segment & $\begin{array}{c}\text { Tank Farm } \\
\text { Sample \# }\end{array}$ & $\begin{array}{c}\text { Shipment } \\
\text { Sample \# }\end{array}$ & $\begin{array}{c}\text { Cask } \\
\text { Serial \# }\end{array}$ & $\begin{array}{c}\text { Date } \\
\text { Sampled }\end{array}$ \\
\hline 53 & 8 & 1 & $93-005$ & S93-006 & $1012 \mathrm{C}$ & $3-19-93$ \\
\hline 53 & 8 & 2 & $93-006$ & S93-006 & C1017 & $3-19-93$ \\
\hline 53 & 8 & Field Blank & N/A & S93-006 & C1024 & $3-22-93$ \\
\hline 54 & 2 & 1 & $93-007$ & S93-007 & $1005 \mathrm{C}$ & $3-24-93$ \\
\hline 54 & 2 & 2 & $93-008$ & S93-007 & $1009 \mathrm{C}$ & $3-24-93$ \\
\hline 57 & 5 & 1 & $93-011$ & S93-010 & C1021 & $5-28-93$ \\
\hline 57 & 5 & $2^{*}$ & $93-012$ & S93-101 & $1002 \mathrm{C}$ & $5-28-93$ \\
\hline 57 & 5 & Field Blank & N/A & S93-010 & $1012 \mathrm{C}$ & $5-28-93$ \\
\hline
\end{tabular}

- Field comment - Strip chart did not work on last sample

Table 3-2. Tank 241-T-105 Lab Tracking Numbers.

\begin{tabular}{|l|c|c|c|c|c|}
\hline \multicolumn{1}{|c|}{ Core } & Segment & $\begin{array}{c}\text { Customer } \\
\text { ID \# }\end{array}$ & $\begin{array}{c}\text { WHC } \\
\text { Tracking \# }\end{array}$ & $\begin{array}{c}\text { Waste } \\
\text { Type }\end{array}$ & $\begin{array}{c}\text { Date } \\
\text { Submitted }\end{array}$ \\
\hline 53 & 1 & C5312 & D7 & Sludge & $4-7-93$ \\
\hline 54 & 1 & C5404 & D8 & Sludge & $4-9-93$ \\
\hline 53 & 1 & C5304 & D9 & Sludge & $4-9-93$ \\
\hline Field Blank & N/A & C5310 & D15 & Water & $4-9-93$ \\
\hline 53 & N/A & C5311 & D16 & Water & $4-12-93$ \\
\hline 54 & 2 & C5302 & D19 & Liquid & $4-19-93$ \\
\hline 53 & 2 & C5402 & D22 & Liquid & $4-19-93$ \\
\hline 53 & CS/H* & C5303 & D25 & Solid & $4-30-93$ \\
\hline 54 & CS/H & C5320 & D28 & Solid & $4-30-93$ \\
\hline 54 & CS/H & C5409 & D33 & Solid & $4-30-93$ \\
\hline 54 & CS/H & C5420 & D37 & Solid & $4-30-93$ \\
\hline 54 & CS/H & C5425 & D40 & Solid & $4-30-93$ \\
\hline 54 & CS/H & C5430 & D41 & Solid & $4-30-93$ \\
\hline 54 & CS/H & C5440 & D42 (PNL)93-0785 & Solid & $5-4-93$ \\
\hline 57 & ---- & C5409 & D47 (PNL)93-0786 & Sludge & $6-2-93$ \\
\hline 57 & 2 & C5705 & D48 (PNL)93-0788 & Sludge & $6-8-93$ \\
\hline Field Blank & N/A & C5709 & --- & Water & --- \\
\hline Hot Cell Blank & N/A & C5710 & --- & Water & --- \\
\hline
\end{tabular}

* $\mathrm{CS} / \mathrm{H}=$ Composite Solids / Homogenized 
Table 3-3. Tank -T- Samples and Requested Analytes.

\begin{tabular}{|c|c|c|c|}
\hline $\begin{array}{l}\text { Tank Farm } \\
\text { Sample } \\
\text { Numbers }\end{array}$ & $\begin{array}{c}\text { Laboratory Sample } \\
\text { Numbers }\end{array}$ & Laboratory & Requested Analytes \\
\hline \multirow[t]{4}{*}{$93-005$} & D-7 & WHC & Particle Size Analysis \\
\hline & D-9 & WHC & DSC, TGA \\
\hline & $D-25$ & WHC & $\begin{array}{l}\text { Flame AA, ICP, Total U, GEA, TA, } \\
\text { TB, }{ }^{238 / 239 / 240} \mathrm{Pu}^{241} \mathrm{Am},{ }^{90} \mathrm{Sr},{ }^{99} \mathrm{Tc}, \\
\mathrm{IC}, \mathrm{NH}_{3}, \mathrm{Cr}(6), \text { TOC, TIC, TDS, GEA, } \\
\text { TA, TB, Bulk Density, CN }, \mathrm{pH}, \mathrm{OH}^{-} \text {, } \\
\text { TOC, wt \% Solids, GHAA- } \mathrm{Hg}\end{array}$ \\
\hline & $D-28$ & WHC & ${ }^{14} \mathrm{C},{ }^{3} \mathrm{H}$, wt $\%$ Solids, GEA \\
\hline $93-006$ & D-19 & WHC & $\begin{array}{l}\mathrm{ICP}, \mathrm{CN}^{-}, \mathrm{IC} \mathrm{NO}_{2}{ }^{-} \text {(spec), } \mathrm{pH}, \mathrm{OH}_{-}, \\
\mathrm{NH}_{3}, \mathrm{TOC}, \mathrm{TIC}, \mathrm{TDS}, \text { Uranium, } \\
{ }^{239 / 240} \mathrm{Pu}, \mathrm{GEA}, \mathrm{Am} / \mathrm{Cm}, \mathrm{TA}, \mathrm{TB}, \\
{ }^{90} \mathrm{Sr}^{99} \mathrm{TC}^{129},{ }^{14} \mathrm{C},{ }^{3} \mathrm{H}, \mathrm{DSC}, \mathrm{TGA}, \\
\mathrm{SpG}\end{array}$ \\
\hline \multirow[t]{7}{*}{$93-007$} & D-8 & WHC & DSC, TGA \\
\hline & D-33 & WHC & $\begin{array}{l}\text { ICP, AA (Cs), Uranium, GEA, TA, TB, } \\
238 / 239 / 240 \mathrm{Pu},{ }^{241} \mathrm{Am},{ }^{\circ 0} \mathrm{Sr},{ }^{99} \mathrm{TC}, 1 \mathrm{C}, \\
\mathrm{NH}_{3}, \mathrm{Cr}(\mathrm{VI}), \mathrm{TOC}, \mathrm{TIC}, \mathrm{TDS}, \mathrm{Bulk} \\
\text { Density, } \mathrm{CN}^{-}, \mathrm{pH}, \mathrm{OH}^{\circ}, \mathrm{GHAA}-\mathrm{Hg}\end{array}$ \\
\hline & $D-37$ & WHC & ${ }^{14} \mathrm{C},{ }^{3} \mathrm{H}$, wt $\%$ Solids, GEA \\
\hline & $D-40$ & WHC & ICP \\
\hline & $D-41$ & WHC & ICP \\
\hline & D-42 (93-07985) & PNL & Isotopic U, Pu \\
\hline & D-47 (93-07986) & PNL & TOC \\
\hline \multirow[t]{2}{*}{$93-008$} & $D-22$ & WHC & $\mathrm{SpG}, \mathrm{IC}, \mathrm{pH}$ \\
\hline & $\begin{array}{l}\text { D-15 Field Blank } \\
\text { D-16 Hot Cell Blank }\end{array}$ & WHC & $\begin{array}{l}\text { IC, } \mathrm{pH}, \mathrm{NH}_{3}, \mathrm{OH}^{-}, \mathrm{TOC}, \mathrm{TIC}, \mathrm{GEA} \text {, } \\
\text { TA, TB, DSC, TGA, ICP }\end{array}$ \\
\hline \multirow[t]{2}{*}{$93-010$} & D-48 (93-07988) & PNL & Density, wt \% Total Solids, \\
\hline & D-49 (93-07987) & PNL & $\begin{array}{l}\text { Density, wt } \% \text { Total Solids, wt } \% \text { and } \\
\text { vol\% Centrifuged Solids }\end{array}$ \\
\hline
\end{tabular}

* Refer to Table 3-4 for abbreviations for analytical methods 
Table 3-4. Standard Abbreviations Describing Analytical Methods.

\begin{tabular}{|c|c|}
\hline \multirow[t]{4}{*}{ Metals: } & ICP - Inductively Coupled Plasma \\
\hline & CVAA - Cold Vapor Atomic Absorption \\
\hline & FAA - Flame Atomic Absorption \\
\hline & GHAA - Gaseous Hydride Atomic Absorption \\
\hline \multirow[t]{2}{*}{ Anions: } & IC - Ion Chromatography \\
\hline & ITS - Potentiometric Titration \\
\hline \multirow[t]{7}{*}{ Radionuclides: } & GEA - Gamma Energy Analysis \\
\hline & AEA - Alpha Energy Analysis \\
\hline & APC - Alpha Proportional Counting \\
\hline & BPC - Beta Proportional Counting \\
\hline & TA - Total Alpha \\
\hline & TB - Total Beta \\
\hline & LSC - Liquid Scintillation Counting \\
\hline \multirow[t]{7}{*}{ Physical Properties: } & DSC - Differential Scanning Calorimetry \\
\hline & DM - Direct Measurement \\
\hline & PT - Physical Testing \\
\hline & TDS - Total Dissolved Solids \\
\hline & TGA - Thermogravimetric Analysis \\
\hline & TIC - Total Inorganic Carbon \\
\hline & TOC - Total Organic Carbon \\
\hline
\end{tabular}




\subsection{SAMPLE HANDLING AND ANALYTICAL SCHEME}

,

The analytical procedures performed on the samples upon receipt from the tank farm sampling activity are the focus of this section.

\subsection{WASTE DESCRIPTION}

The segments obtained from core sampling activities in Tank 241-T-105 were a mixture of air, liquids, and solids. The following is a description of the contents of each core segment (Kocher, 1993 and Giamberardini, 1993).

\section{Core 53}

Segment 1 - Solids comprised $18 \%$, or $33.66 \mathrm{~mL}$, of the $187 \mathrm{~mL}$ volume of the sampler. The solids were brown, homogeneous, of a muddy texture, and had no crust. No drainable liquid was recovered; however, $11.32 \mathrm{~g}$ of liner liquid (liquid which drains from the sample as contamination into the sample liner, or from head fluid) was obtained. Eighty-two percent $(82 \%)$, or $153.34 \mathrm{~mL}$, of the sampler volume was occupied by air.

Segment 2 - Less than $3 \%$ of the $187 \mathrm{~mL}$ sampler volume was occupied by solid material. $41 \%$, or $76.67 \mathrm{~mL}$, of the sample was air, and $56 \%$, or $104.72 \mathrm{~mL}$, of the sample was liquid. $96.7 \mathrm{~g}$ of drainable liquid and $11.24 \mathrm{~g}$ of liner liquid were collected. The volume of drainable liquid recovered was $85 \mathrm{~mL}$ due to a loss of approximately $10-20 \mathrm{~mL}$ that ejected off the sample tray.

\section{Core 54}

Segment 1 - The recovered material was predominantly solid, making up $31 \%$, or $57.97 \mathrm{~mL}$, of the $187 \mathrm{~mL}$ sample volume. In appearance, the material was dark brown to white in color. The texture was smooth and wet. The segment was nonhomogeneous. Five percent (5\%), or $9.35 \mathrm{~mL}$, of the sample volume was occupied by liquid. The remaining $64 \%$, or 119.68 $\mathrm{mL}$, of the sample volume was comprised of air. In addition, $13.8 \mathrm{~g}$ of drainable liquid, and $0.8 \mathrm{~g}$ of liner liquid were recovered. The volume of drainable liquid was $10 \mathrm{~mL}$.

Segment 2 - Most of the recovered sample, $91 \%$, or $170 \mathrm{~mL}$, was comprised of liquid. The net weight of the liquid was $164.53 \mathrm{~g}$. The remaining $9 \%$ of the sample volume was occupied by air. There were no solids recovered. In addition to the drainable liquid, about $4.94 \mathrm{~g}$ of liner liquid was recovered.

\section{Core 57}

Segment 1 - Dry solids of approximately 1.5 inches were extruded from the sampler. No drainable liquid was recovered, and there was no liner liquid. Breakdown of the sampler volume is a follows; $92 \%$ air, $0 \%$ liquid, and $8 \%$ solids $(16.4 \mathrm{~g})$. The solids were dark brown, cohesive, dry and homogeneous. No subsampling was performed. 
Segment 2 - Damp solids of approximately 1.5 inches were extruded comprising $8 \%(16 \mathrm{~g})$ of the sampler volume. No drainable liquid was recovered, and $92 \%$ of the $187 \mathrm{~mL}$ sampler volume was air. The solids were cream and dark brown in color with runny liquid. The sample was nonhomogeneous; the texture was runny and soft. No subsampling was performed on the sample.

\subsection{HOLD TIME CONSIDERATIONS}

For hold time considerations, see the Tank Characterization Reference Guide (De Lorenzo et al., 1994).

\subsubsection{WHC - 222-S Laboratory}

Core 53 was obtained from. Tank $241-T-105$ by Sampling Operations personnel on 3/19/93. A field blank was obtained on $3 / 22 / 93$, and Core 54 was obtained on $3 / 24 / 93$. The samples were received by the 222-S Laboratory from $3 / 22 / 93$ to $3 / 29 / 93$ without preservation (no acidification or refrigeration). Analyses by the 222-S Laboratory were performed on Cores 53 and 54 between 4/14/93 and 8/27/93 (Kocher, 1993).

\subsubsection{PNL - 325 Laboratory}

Core 57. was obtained on 5/28/93. Pacific Northwest Laboratory's (PNL) 325 Laboratory received Core 57 and aliquots from Core 54 on 6/14/93, without refrigeration or acidification. Physical properties of the samples were analytically determined by PNL between 7/13/93 and 9/7/93 (Giamberardini, 1993)

\subsection{SAMPLE PREPARATION}

For a discussion of sample preparation procedures, see the Tank Characterization Reference Guide (De Lorenzo, et al., 1994).

\subsection{ANALYTICAL METHODS}

This section lists the analytes and the respective analytical procedures that were used to characterize the waste in Tank 241-T-105. Procedures used for inorganic and radiochemical analyses are listed in Table 4-1. Procedures used for physical and rheological analyses are listed in Table 4-2.

Of the three cores $(53,54$, and 57) which were obtained from Tank 241-T-105, Core 53 was analyzed only at the 222-S Laboratory, Core 54 was analyzed at both 222-S and the PNL Laboratory. Core 57 was analyzed exclusively at PNL. PNL performed analyses on Core 54, Segment 1, for Plutonium, Isotopic Uranium, and Total Organic Carbon. PNL performed analyses on Core 57, Segment 1 for Physical Properties (wt\% and density of total solids, and vol\% and $w t \%$ on the centrifuged solids). Core 57, Segment 2 analyses by PNL included $w t \%$, total solids, and density. The 222-S Laboratory performed the remaining analyses for metals, ions, radionuclides, and physical properties (Kocher, 1993 and Giamberardini, 1993). Analyses for organic constituents were not performed on Tank 241-T-105. 
Table 4-1. Inorganic and Radiochemical Analytical Methods. (Kocher, 1993)

\begin{tabular}{|c|c|c|}
\hline Analyte & Method & Procedụre \\
\hline Total Metals & $\begin{array}{l}\text { Inductively Coupled Plasma } \\
\text { Spectrometry }\end{array}$ & LA-505-151 \\
\hline $\mathrm{Cr}$ (VI) & Spectrophotometry & LA-265-101 \\
\hline $\mathrm{Hg}$ & Cold Vapor Atomic Absorption & LA-325-102 \\
\hline $\begin{array}{l}\mathrm{F}^{-}, \mathrm{Cl}^{-}, \mathrm{NO}_{3}^{-}, \mathrm{NO}_{2}{ }^{-}, \mathrm{PO}_{4}{ }^{3-}, \\
\mathrm{SO}_{4}{ }^{2-}\end{array}$ & Ion Chromatography & LA-533-105 \\
\hline $\mathrm{NO}_{2}^{-}$ & Absorbance Spectrometer & LA-645-001 \\
\hline $\mathrm{OH}^{-}$ & Potentiometric Titration & LA-661-102 \\
\hline Total Organic Carbon & Coulometry & $\begin{array}{l}\text { LA-622-102/ } \\
\text { PNL-ALO-381 }\end{array}$ \\
\hline Total Inorganic Carbon & Coulometry & $\begin{array}{l}\text { LA-344-105/ } \\
\text { PNL-ALO-381 }\end{array}$ \\
\hline $\mathrm{CN}^{-}$ & Distillation/Spectrometry & $\begin{array}{l}\text { LA-695-101/ } \\
\text { LA-695-102 }\end{array}$ \\
\hline $\mathrm{NH}_{3}$ & Distillation/Titration & LA-634-102 \\
\hline Total Uranium & Laser Fluorimetry & LA-925-106 \\
\hline Total Alpha & Alpha Proportional Counting & LA-508-101 \\
\hline Total Beta & Beta Proportional Counting & LA-508-101 \\
\hline${ }^{137} \mathrm{Cs},{ }^{60} \mathrm{Co},{ }^{241} \mathrm{Am}$ & Gamma Energy Analysis & LA-548-121 \\
\hline Isotopic Uranium, Plutonium & Mass Spectrometry & PNL-ALO-455 \\
\hline${ }^{239 / 240} \mathrm{Pu},{ }^{241} \mathrm{Am}$ & Alpha Spectrometry & $\begin{array}{c}\text { LA-503-156/ } \\
\text { PNL-ALO-423/421 }\end{array}$ \\
\hline${ }^{237} \mathrm{~Np}$ & Extraction/Alpha Energy Analysis & LA-933-141 \\
\hline${ }^{90} \mathrm{Sr}$ & Extraction/Beta Proportional Counting & LA-220-101 \\
\hline${ }^{99} \mathrm{Tc}$ & Liquid Scintillation Counting & $\mathrm{LA}-438-101$ \\
\hline${ }^{79} \mathrm{Se}$ & Liquid Scintillation Counting & LA-365-132 \\
\hline $129 \mid$ & Gamma Energy Analysis & LA-378-101 \\
\hline${ }^{14} \mathrm{C}$ & Liquid Scintillation Counting & LA-348-104 \\
\hline${ }^{3} \mathrm{H}$ & Liquid Scintillation Counting & LA-218-113 \\
\hline $\mathrm{pH}$ & Direct & LA-212-103 \\
\hline
\end{tabular}


Table 4-2. Physical and Rheological Analytical Methods.

\begin{tabular}{|l|l|c|}
\hline \multicolumn{1}{|c|}{ Analyte } & \multicolumn{1}{|c|}{ Method } & Procedure \\
\hline Thermal Properties & $\begin{array}{l}\text { Thermogravimetric Analysis/ } \\
\text { Differential Scanning Calorimetry }\end{array}$ & $\begin{array}{c}\text { LA-561-112/ } \\
\text { LA-514-113 }\end{array}$ \\
\hline \% water/Total dissolved Solids & Thermogravimetric Analysis & $\begin{array}{c}\text { LA-564-101/ } \\
\text { PNL-ALO-504 }\end{array}$ \\
\hline Specific Gravity & Direct & LA-510-112 \\
\hline Density & Direct & PNL-ALO-501 \\
\hline Rheology & Direct & $\begin{array}{c}\text { PNL-ALO-501 } \\
\text { PNL-ALO-502 }\end{array}$ \\
\hline Particle Size & Direct & $\begin{array}{c}\text { Proc. Instr. } \\
599-2-50.3\end{array}$ \\
\hline
\end{tabular}

\subsubsection{Chemical and Radionuclide Analyses Quality Control}

Quality control procedures were conducted in accordance with the requirements listed in Bell (1994). In summary, those requirements are:

- one laboratory control standard per analytical batch,

- one blank per batch,

- one matrix spike per core or per matrix,

- $100 \%$ duplicates on all homogenization test samples and core composite samples,

- one duplicate per analytical batch for direct segment samples,

- a duplicate to verify each detected exotherm for DSC analysis.

Exceptions are allowed for specific analytes or procedures:

- $\%$ water is always run in duplicate,

- $\quad{ }^{90} \mathrm{Sr},{ }^{79} \mathrm{Se},{ }^{99} \mathrm{Tc},{ }^{129} \mathrm{l}, \mathrm{Pu}$, and ${ }^{241} \mathrm{Am}$ have a spike or carrier added to each sample, so no additional matrix spikes are required,

- $\quad$ GEA and $\mathrm{pH}$ do not require a spike,

- a matrix spike for ${ }^{237} \mathrm{~Np}$ is requested on each sample,

- ICP, GHAA, CVAA, and IC require additional, method specific quality control procedures. Instrument calibration and check standards are run according to specific procedure protocols. 


\subsection{MODULE SPECIFIC ANALYSES}

- The characterization program for Tank 241-T-105 was intended to satisfy criteria set by the Tank Waste Remediation System (TWRS). The TWRS sample characterization objectives are to provide adequate description of physical, chemical, and radiological properties of Hanford Site tank wastes to support resolution of Unreviewed Safety Questions, other safety issues surrounding the Watch-List tanks, and the design of retrieval, pretreatment and final disposal systems (Bell, 1994). The waste in Tank 241-T-105 was analyzed to provide sufficient information to determine with confidence that constituent concentrations are within safe operating limits. 


\subsection{ANALYTICAL RESULTS AND WASTE INVENTORY}

The chemical, radiochemical, and physical results associated with Tank 241-T-105 are presented within this document as indicated in Table 5-1. The samples from which these results were derived were collected on March 19, 22, and 24 of 1993 and May 28, 1993. These sampling events are the most recent regarding Tank 241-T-105 and reflect the most accurate characterization of the tank waste available at the present time.

Table 5-1. Analytical Data Presentation Tables.

\begin{tabular}{|l|l|}
\hline \multicolumn{1}{|c|}{ Analysis } & Tabulated Results \\
\hline Metals & Table A-1 \\
\hline lons & Table A-2 \\
\hline Radionuclides & Table A-3 \\
\hline Physical Properties and Miscellaneous Chemical Data & Table A-4 \\
\hline Characterization Report Results for Tank 241-T-105 & Table 5-7 \\
\hline
\end{tabular}

In cases where a duplicate analysis was performed on a sample, the data presented in the Appendix A tables were obtained by calculating an average concentration value from the initial and duplicate results. If an analyte was detected by the original but not by the duplicate sample evaluation, or vice-versa, only the single positive result was reported. When both sample runs failed to detect an analyte, the detection limit preceded by a less than $(<)$ sign was recorded as the sample result.

A representative tank concentration for each analyte is included with the Appendix A tables. The liquid and solid laboratory data were treated separately. These values were derived by calculating simple means from samples which yielded analyte concentrations above reported detection limits. A conservative approach was exercised in order to evaluate the data; therefore, where applicable, the representative tank concentration for each analyte was derived from the group of samples associated with the preparation procedure which yielded the greatest average value. If all available sample analyses failed to detect a particular analyte, the tank concentration of the analyte was reported to be less than the highest recorded detection limit. Detection limit values were not utilized to calculate means nor corresponding standard deviation values.

The range of the tabulated sample data associated with each analyte is also included in the Appendix A tables. The projected tank inventory value reported in the Appendix $A$ tables was obtained by multiplying the representative tank concentration of each analyte by the volume of waste in the tank. At the time of sampling, the tank contained 371,000 liters of waste. The appropriate conversion factors were included in the calculations to obtain the reported units. 


\subsection{CHEMICAL ANALYSES}

\subsubsection{Elemental Constituents}

The major waste constituents identified by Inductively Coupled Plasma (ICP) spectroscopy were $\mathrm{Al}, \mathrm{Bi}, \mathrm{Ca}, \mathrm{Fe}, \mathrm{Mg}, \mathrm{Mn}, \mathrm{P}, \mathrm{Si}, \mathrm{Na}, \mathrm{S}$, and $\mathrm{U}$; all were present in concentrations exceeding $1000 \mu \mathrm{g} / \mathrm{g}$. These were analyzed either by acid digestion, water digestion, or $\mathrm{KOH}$ fusion digested. Cesium was not detected by the ICP analysis; therefore, the reported value for cesium metal was calculated from the gamma energy analysis data.

The historical estimates (from Table 2-3) for $\mathrm{Al}, \mathrm{Bi}, \mathrm{Cr}, \mathrm{Fe}, \mathrm{Na}$, and $\mathrm{U}$ (Agnew, 1994) were available for comparison with the analytical data; a historical comparison regarding phosphorous is discussed in section 5.1.2. The corresponding relative percent differences between the two sources are presented in Table 5-2 and demonstrate that the analytical results are not very consistent with the historical estimates.

Table 5-2. Comparison of Analytical and Historical Data for Elemental Constituents.

\begin{tabular}{|c|c|c|c|}
\hline Analyte & $\begin{array}{c}\text { Lab Result }^{(\mathbf{a})} \\
(\boldsymbol{\mu} \mathbf{g} / \mathbf{g})\end{array}$ & $\begin{array}{c}\text { Historical Estimate } \\
(\boldsymbol{\mu g} / \mathbf{g})\end{array}$ & $\begin{array}{c}\text { Relative Percent } \\
\text { Difference (RPD) }\end{array}$ \\
\hline $\mathrm{Al}$ & 95,100 & 27,900 & $109 \%$ \\
\hline $\mathrm{Bi}$ & 1,330 & 16,600 & $-170 \%$ \\
\hline $\mathrm{Cr}$ & 505 & 455 & $10 \%$ \\
\hline $\mathrm{Fe}$ & 33,100 & 10,400 & $104 \%$ \\
\hline $\mathrm{Na}$ & 56,300 & 61,300 & $-9 \%$ \\
\hline $\mathrm{U}$ & 9,120 & 12,200 & $-29 \%$ \\
\hline
\end{tabular}

$\mathrm{a}=$ lab result

$\mathrm{b}=$ historical data

$R P D=\left((a-b) / \frac{(a+b)}{2}\right) \times 100$

\subsubsection{Anions}

The most abundant anion in the waste of Tank 241-T-105 was nitrite which had a concentration of $12,300 \mu \mathrm{g} / \mathrm{g}$. Nitrate exhibited the second highest concentration among anions. Sulfate, phosphate, chloride, and fluoride were present in the tank to a lesser extent.

After calculating a value for phosphate and sulfate from the phosphorous and sulfur data derived from the ICP analyses, the results were compared to the phosphate and sulfur data obtained by ion chromatography (IC). The comparison is displayed in Table 5-3, and inspection of the table reveals a large discrepancy between the two values. Since much of the phosphate in Tank 241-T-105 exists as a precipitate, the water digested liquid samples associated with the $\mathrm{IC}$ analyses would not be expected to detect as much phosphorous, in the form of phosphate, as KOH fusion prepared samples evaluated by ICP analysis. Therefore, the phosphate result calculated from the ICP data is considered to be more accurate for 
providing bulk inventories. This conclusion is also supported by the historical data as indicated in Table 5-3. Much of the sulfate in the tank is soluble, therefore the water digested liquid sample associated with the IC analyses would detect more sulfur in the form of sulfate than the ICP analysis. The sulfate result from the IC data is more accurate. This is supported by the historical data as shown in Table 5-3.

Table 5-3. Comparison of Analytical and Historical Results for Tank 241-T-105 Anions.

\begin{tabular}{|l|c|c|c|}
\hline \multicolumn{1}{|c|}{ Analyte } & $\begin{array}{c}\text { Lab Result } \\
(\mu \mathrm{g} / \mathrm{g})\end{array}$ & $\begin{array}{c}\text { Historical Estimate } \\
(\mu \mathrm{g} / \mathrm{g})\end{array}$ & $\begin{array}{c}\text { Relative Percent } \\
\text { Difference \% }\end{array}$ \\
\hline Fluoride & 1.26 & 5,500 & $-200 \%$ \\
\hline Nitrate & 21,200 & 42,600 & $-67 \%$ \\
\hline Phosphate (IC) & 2,190 & 35,300 & $-177 \%$ \\
\hline Phosphate (ICP) & 7,710 & 35,300 & $-128 \%$ \\
\hline Sulfate (IC) & 8,530 & 2,800 & $101 \%$ \\
\hline Sulfate (ICP) & 13,600 & 2,800 & $132 \%$ \\
\hline
\end{tabular}

Historical estimates for nitrate, phosphate, sulfate, and fluoride (Agnew, 1994) were available for comparison with the analytical data, and the relative percent differences between the two sources are presented in Table 5-3. As indicated by the table, the values do not demonstrate good agreement. The historical data underestimated sulfate concentrations but overestimated fluoride, nitrate, and phosphate. The fluoride result is low which could be because large amounts of dilute aqueous wastes were processed through after highly caustic REDOX coating waste. There might have been some "washing" of the solids and very little soluble anions remain in the waste, especially in the upper portion of the tank.

\subsection{RADIOLOGICAL DETERMINATIONS}

The major radioactive constituents in the waste were ${ }^{137} \mathrm{Cs}$ and ${ }^{90} \mathrm{Sr}$. The following analytes which are of concern with respect to radioactivity were estimated from historical records (Agnew, 1994): ${ }^{137} \mathrm{Cs},{ }^{90} \mathrm{Sr}$, and isotopic $\mathrm{Pu}$. The analytical and historical results are compared in Table 5-4, and the table demonstrates poor agreement between the two sources of data for all results. As is the case for elements and anions, the degree of difference shows that historical knowledge only provides a general framework for understanding and is not complete.

Table 5-4. Comparison of Analytical and Historical Isotopic Results.

\begin{tabular}{|l|c|c|c|}
\hline \multicolumn{1}{|c|}{ Analyte } & $\begin{array}{c}\text { Lab Result } \\
(\mu \mathrm{Ci} / \mathrm{g})\end{array}$ & $\begin{array}{c}\text { Historical Estimate } \\
(\boldsymbol{\mu C i} / \mathrm{g})\end{array}$ & $\begin{array}{c}\text { Relative Percent } \\
\text { Difference \% }\end{array}$ \\
\hline${ }^{137} \mathrm{Cs}$ & 55.6 & 4.44 & $170 \%$ \\
\hline Isotopic $\mathrm{Pu}$ & 0.139 & 0.395 & $-96 \%$ \\
\hline${ }^{90} \mathrm{Sr}$ & 281 & 3.56 & $195 \%$ \\
\hline
\end{tabular}




\section{Alpha Emitters}

The ${ }^{241}$ Am result shown in Table 5-7 is from the Alpha spectroscopy analysis rather than GEA analysis. There is poor agreement between the alpha emitters and the total alpha as shown in Table 5-4a.

Table 5-4a. Activity Due to Alpha Radiation.

\begin{tabular}{|l|c|}
\hline \multicolumn{1}{|c|}{ Isotope } & $\begin{array}{c}\text { Laboratory Result } \\
(\boldsymbol{\mu C i} / \mathbf{g})\end{array}$ \\
\hline${ }^{241} \mathrm{Am}$ & 0.395 \\
\hline${ }^{239 / 240} \mathrm{Pu}$ & 0.139 \\
\hline Total Alpha & 0.278 \\
\hline
\end{tabular}

Due to this discrepancy, it is assumed that the total alpha is mainly Pu with very little Am. Referring to Table A-3 in Appendix A, $96.469 \%$ and $3.188 \%$ are ${ }^{239} \mathrm{Pu}$ and ${ }^{240} \mathrm{Pu}$ respectively. Therefore, $0.277 \mu \mathrm{Ci} / \mathrm{g}^{*}$ of the total alpha is ${ }^{239 / 240} \mathrm{Pu}$ and $0.001 \mu \mathrm{Ci} / \mathrm{g}$ is ${ }^{241} \mathrm{Am}$.

$\cdot(96.469 \%$ of 0.278$)+(3.188 \%$ of 0.278$)=0.277 \mu \mathrm{Ci} / \mathrm{g}$

\section{Beta Emitters}

A comparison was also made between the gross Beta result and the sum of the dividual Beta emitters. This was done to determine the level of agreement between the two salues. The activity of the individual Beta emitters is summed by using the following equation:

$$
2\left[{ }^{90} \mathrm{Sr}(1.42)\right]+{ }^{137} \mathrm{Cs}(1.51) .
$$

The coefficients, 1.42 and 1.51 , are the corrections for calibration of the detector with ${ }^{60} \mathrm{Co}$. The total beta results are based on the efficiency of the detector for ${ }^{60} \mathrm{Co}$. Since the ${ }^{60} \mathrm{Co}$ is lower in energy than the isotopes, the total beta results are usually biased high. To correct for this, the efficiency factor is taken into account. As seen in Table $5-4 b$ there is good agreement between the total beta sum and gross beta results (RPD is $-1.83 \%$ ).

Table 5-4b. Activity Due to Beta Radiation.

\begin{tabular}{|l|c|}
\hline \multicolumn{1}{|c|}{ Analyte } & $\mu \mathrm{Ci} / \mathrm{g}$ \\
\hline${ }^{90} \mathrm{Sr}$ & 281 \\
\hline${ }^{137} \mathrm{Cs}$ & 55.6 \\
\hline Total Beta sum ${ }^{+}$ & 882 \\
\hline Gross Beta result & 866 \\
\hline
\end{tabular}

$$
+2\left[{ }^{90} \mathrm{Sr}(1.42)\right]+{ }^{137} \mathrm{Cs}(1.51)
$$




\subsection{ORGANIC CONSTITUENTS}

Volatile and semi-volatile organic analyses were not conducted on samples obtained from Tank 241-T-105. However, volatile and semivolatile target analytes are not expected to be present in the tank due to their volatile nature and relatively small contribution to the waste as indicated by the historical records. Data from the total organic carbon analysis reveal that organic carbon does exist in Tank 241-T-105, most likely in the form of complexant decomposition products.

\subsection{PHYSICAL MEASUREMENTS}

\subsubsection{Density and Percent Solids}

\section{PNL 325 Laboratory}

Density and percent solids (Wt\% and Vol\%) analyses were performed by the PNL 325 Laboratory on Segments 1 and 2 of Core 57 . Wt\% solids only were performed on Core 54, Segment 1. The density and percent solids data are shown in Table 5-5. Density measurements were determined directly. The density of Core 57 Segment 1 was found to be $1.54 \mathrm{~g} / \mathrm{mL}$, and that of Core 57 Segment 2 was $1.74 \mathrm{~g} / \mathrm{mL}$. In addition to the density of the core samples, density measurements were made of the Core 57 Segment 1 centrifuged supernate (1.0), and the centrifuged solids (1.56). Wt\% percent solids of Cores 54 and 57 were determined thermogravimetrically. Percent total solids results were $52.0 \mathrm{wt} \%$, and 75.0 $w t \%$ for Core 57, Segment 1 and 2, respectively. Core 54 Segment 1 percent total solids result was $75.6 \mathrm{wt} \%$.

In addition to wt\% total solids, wt \% analyses were performed on centrifuged solids from Core 57 Segment 1, exhibiting a result of $98 \%$ wt. Vol\% analyses were performed on settled solids from Core 57 Segment 1 and 2 . The vol\% results for both segments were 100 vol\%, showing that no drainable liquid existed in the samples. Centrifuged solids exhibited vol\% results of 96 vol\% and 98 vol\% for Segments 1 and 2, respectively.

\section{WHC 222-S Laboratory}

Wt\% solids analyses were performed by the 222-S Laboratory on the homogenized samples made up from Core 54, Segments 1 and 2 . The results were $73.39 \mathrm{wt} \%$ and 74.9 wt. \%, respectively. Efforts to measure wt\% solids on Core 53 homogenized sample were unsuccessful due to insufficient sample.

Specific gravity was measured on Segment 2 from Cores 53 and 54 . The results for the drainable liquid samples were 1.05 on Core 53 , and 0.985 on Core 54 .

\subsubsection{Particle Size}

\section{PNL 325 Laboratory}

Particle size was measured on Segments 1 and 2 from Core 57. The results in Table 5-5 were similar for both segments. The mean diameter based on probability number density was 1.0 microns. The mean diameter based on probability volume density was 9 microns for Segment 1 and 16 microns for Segment 2. The results show indications of heterogeneity. 
Table 5-5. Tank 241-T-105 Physical Properties.

\begin{tabular}{|c|c|c|c|c|c|c|}
\hline \multirow[b]{2}{*}{ Physical Property } & \multicolumn{2}{|c|}{ Core 53} & \multicolumn{2}{|c|}{ Core 54} & \multicolumn{2}{|c|}{ Core 57} \\
\hline & $\begin{array}{c}\text { Segment } \\
1\end{array}$ & $\begin{array}{c}\text { Segment } \\
2\end{array}$ & $\begin{array}{c}\text { Segment } \\
1\end{array}$ & $\begin{array}{c}\text { Segment } \\
2\end{array}$ & $\underset{1}{\text { Segment }}$ & $\begin{array}{c}\text { Segment } \\
2\end{array}$ \\
\hline Total Solids Wt\% & -- & --- & 73.39 & 74.9 & 52.0 & 75.0 \\
\hline $\begin{array}{l}\text { Total Dissolved } \\
\text { Solids }(\%)\end{array}$ & 0.280 & --- & 0.105 & --- & -- & --- \\
\hline $\begin{array}{l}\text { Settled Solids } \\
\text { Vol\% }\end{array}$ & -- & --- & -- & --- & 100 & 100 \\
\hline $\begin{array}{l}\text { Centrifuged Solids } \\
\text { Wt\% }\end{array}$ & $\cdots$ & --- & $-\cdots$ & --- & 98 & 98 \\
\hline $\begin{array}{l}\text { Centrifuged Solids } \\
\text { Vol\% }\end{array}$ & -- & $\cdots$ & $\cdots$ & -- & 96 & --- \\
\hline $\begin{array}{l}\text { Sample Density } \\
\text { (Specific Gravity) } \\
\text { Drainable Liquid }\end{array}$ & --- & $(1.05)$ & --- & $(0.985)$ & 1.54 & 1.74 \\
\hline $\begin{array}{l}\text { Centrifuged } \\
\text { Supernate Density }\end{array}$ & --- & --- & --- & $-\cdots$ & 1.0 & --- \\
\hline $\begin{array}{l}\text { Centrifuged Solids } \\
\text { Density }\end{array}$ & --- & --- & --- & --- & 1.56 & --- \\
\hline Particle Size - WHC & $0.50 \mu$ & --- & $0.50 \mu$ & $-\cdots$ & -- & -- \\
\hline Particle Size - PNL & -- & -- & -- & --- & $\begin{array}{l}1.0 \mu^{1} \\
9 \mu^{2}\end{array}$ & $\begin{array}{l}1.0 \mu^{1} \\
16 \mu^{2}\end{array}$ \\
\hline
\end{tabular}

1. Based on probability number density.

2. Based on probability volume density.

\section{WHC 222-S Laboratory}

Particle size was measured on samples from both Core 53 and Core 54 , segments 1 . In all cases, the probable particle size was less than .50 microns. There is no available information as to whether these are based on Number density or Volume density.

\subsubsection{Rheology}

Viscosity versus shear rate studies were performed on samples obtained from segments 1 and 2 of core 57 . Segment 1 exhibited pseudoplastic behavior; that is, the viscosity of the waste decreased with increasing shear rate. The viscosity of a 1:1 dilution of segment 1 at ambient temperature decreased from 200 centipoise to 20 centipoise as shear rate increased from $50 \mathrm{~s}^{-1}$ to $450 \mathrm{~s}^{-1}$. These data fit the Power Law Parameters as shown in Table 5-6. The 1:1 dilution of segment 2, however, displayed Newtonian behavior since the viscosity was relatively independent of shear rate; a slight decrease from 5 centipoise to 1 centipoise was observed as shear rate increased from $50 \mathrm{~s}^{-1}$ to $450 \mathrm{~s}^{-1}$. 
Table 5-6. The Power Law Parameters for Segment 1, 1:1 dilution.

\begin{tabular}{|c|c|c|c|c|}
\hline Temperature & : Run & $\begin{array}{c}\text { Yield Part } \\
\text { (Pa) }\end{array}$ & $\begin{array}{c}\text { Consistency } \\
\text { Parameter (Pa Sec) }\end{array}$ & $\begin{array}{c}\text { Flow Behavior } \\
\text { Index }\end{array}$ \\
\hline 25 & 1 & 6.8 & 0.036 & 0.74 \\
\hline 25 & 2 & 6.0 & 0.028 & 0.86 \\
\hline
\end{tabular}

\subsubsection{Energetics}

Differential scanning calorimetry (DSC) yielded slight exotherms in samples originating from cores 53 and 57; however, exotherms were not observed in core 54 samples. The DSC plots of the samples generally yielded two endothermic transition regions. The first transition region consists of a peak attributed to the evaporation of interstitial and hydrated water. The second endothermic region occurs at approximately $280^{\circ} \mathrm{C}$ and may be caused by a melting salt.

The exotherms associated with core 53 were observed at approximately $333^{\circ} \mathrm{C}$ and $447^{\circ} \mathrm{C}$ and released $13.0 \mathrm{~J} / \mathrm{g}(3.11 \mathrm{cal} / \mathrm{g})$ and $17.3 \mathrm{~J} / \mathrm{g}(4.14 \mathrm{cal} / \mathrm{g})$, respectively. Whereas, Core $57 \mathrm{had}$ a broad exotherm in the $150-320^{\circ} \mathrm{C}$ range with an average $175 \mathrm{~J} / \mathrm{g}(41.8 \mathrm{cal} / \mathrm{g}$ ) energy release. Even though these exotherms have been observed and quantified, they are below the Safety Screening criterion of $<125 \mathrm{cal} / \mathrm{g}$ (Babad, 1994). These exotherm values are on a wet sample basis.

\subsection{DATA PRESENTATION}

The Tank Characterization Report Results displayed in Table 5-7 are the final constituent estimates for this document. The values are equal to either the "Evaluated Data Result" or "Largest Detection Limit" recorded in the Appendix A tables. If laboratory results were not available for an analyte, the Tank Characterization Result was, if possible, estimated from historical records. 
Table 5-7. Tank Characterization Report Data in Single-Shell Tank 241-T-105. (3 pages)

\begin{tabular}{|c|c|c|c|}
\hline Analyte & $\begin{array}{c}\text { Historic Tank } \\
\text { Content } \\
\text { Estimate } \\
\end{array}$ & $\begin{array}{c}\text { Tank } \\
\text { Characterization } \\
\text { Report }\end{array}$ & $\begin{array}{l}\text { Total Tank } \\
\text { Inventory }\end{array}$ \\
\hline Cations & $(\mu \mathrm{g} / \mathrm{g})$ & $(\mu \mathrm{g} / \mathrm{g})$ & $(\mathrm{kg})$ \\
\hline Aluminum (Al) & 27,900 & 95,100 & 57,800 \\
\hline Antimony (Sb) & --- & 23.7 & 14.4 \\
\hline Arsenic (As) & $\cdots$ & 26.0 & 15.8 \\
\hline Barium (Ba) & --- & --- & --- \\
\hline Beryllium $(\mathrm{Be})$ & --- & 3.08 & 1.87 \\
\hline Bismuth (Bi) & 16,600 & 1,330 & 809 \\
\hline Boron (B) & --- & 335 & 204 \\
\hline Cadmium (Cd) & --- & 15.4 & 9.36 \\
\hline Calcium (Ca) & --- & 3,670 & 2,230 \\
\hline Cerium $(\mathrm{Ce})$ & $\cdots$ & 79.0 & 48.0 \\
\hline Cesium (Cs) & --- & $<1000$ & $<608$ \\
\hline Chromium (Cr) & 455 & 505 & 307 \\
\hline Cobalt (Co) & -- & -- & --- \\
\hline Copper $(\mathrm{Cu})$ & -- & --- & --- \\
\hline Dysprosium (Dy) & --- & --- & --- \\
\hline Iron (Fe) & 10,400 & 33,100 & 20,100 \\
\hline Lanthanum (La) & -- & 24.3 & 14.8 \\
\hline Lead $(\mathrm{Pb})$ & --- & 534 & 325 \\
\hline Lithium (Li) & --- & 4.22 & 669 \\
\hline Magnesium (Mg) & --- & 1,100 & 2.57 \\
\hline Manganese $(\mathrm{Mn})$ & -- & 11,600 & 7,050 \\
\hline Mercury $(\mathrm{Hg})$ & $\cdots$ & 23.9 & 14.5 \\
\hline Molybdenum (Mo) & --- & 34.7 & 21.1 \\
\hline Neodymium (Nd) & --- & 152 & 92.4 \\
\hline Neptunium (Np) & --- & --- & --- \\
\hline Nickel (Ni) & $\cdots$ & 81.3 & 49.4 \\
\hline Phosphorus (P) & --- & 1,530 & 930 \\
\hline Plutonium (Pu) & --- & --- & --- \\
\hline Potassium (K) & --- & 305 & 185 \\
\hline Rhenium (Re) & $\cdots$ & --- & --- \\
\hline Rhodium (Rh) & -- & $\cdots$ & --- \\
\hline Ruthenium (Ru) & --- & --- & -- \\
\hline Samarium (Sm) & -- & 70.4 & 45.2 \\
\hline
\end{tabular}


Table 5-7. Tank Characterization Report Data in Single-Shell Tank 241-T-105. (3 pages)

\begin{tabular}{|c|c|c|c|}
\hline Analyte & $\begin{array}{c}\text { Historic Tank } \\
\text { Content } \\
\text { Estimate }\end{array}$ & $\begin{array}{c}\text { Tank } \\
\begin{array}{c}\text { Characterization } \\
\text { Report }\end{array} \\
\end{array}$ & $\begin{array}{l}\text { Total Tank } \\
\text { Inventory }\end{array}$ \\
\hline Cations (continued) & $(\mu \mathrm{g} / \mathrm{g})$ & $(\mu \mathrm{g} / \mathrm{g})$ & $(\mathrm{kg})$ \\
\hline Selenium (Se) & --- & 74.7 & 45.4 \\
\hline Silicon (Si) & 2,870 & 6,980 & 4,200 \\
\hline Silver $(\mathrm{Ag})$ & -- & 46.2 & 28.1 \\
\hline Sodium (Na) & 61,300 & 56,300 & 34,200 \\
\hline Strontium (Sr) & -- & 148 & 93.6 \\
\hline Sulfur (S) & $\ldots$ & 2,760 & 1,680 \\
\hline $\operatorname{Tin}(S n)$ & --- & $\ldots$ & $-\cdots$ \\
\hline Tellurium $(\mathrm{Te})$ & $\cdots$ & --- & --- \\
\hline Thorium (Th) & -- & $-\cdots$ & --- \\
\hline Thallium (TI) & --- & 101 & 61.4 \\
\hline Titanium $(\mathrm{Ti}\rangle$ & $-\cdots$ & 228 & 139 \\
\hline Uranium (U) & 12,200 & 9,120 & 5,550 \\
\hline Vanadium (V) & --- & -- & --- \\
\hline Zinc $(Z n)$ & $\cdots$ & $\cdots$ & --- \\
\hline Zirconium $(\mathrm{Zr})$ & 309 & 119 & 72.4 \\
\hline lons & $(\mu \mathrm{g} / \mathrm{g})$ & $(\mu \mathrm{g} / \mathrm{g})$ & (kg) \\
\hline Ammonia $\left(\mathrm{NH}_{3}\right)$ & -- & $<400$ & $<148$ \\
\hline Carbonate $\left(\mathrm{CO}_{3}{ }^{2-}\right)$ & $-\cdots$ & $\cdots$ & -- \\
\hline Chloride $\left(\mathrm{Cl}^{-}\right)$ & --- & 402 & 149 \\
\hline Chromium (VI) $\left(\mathrm{Cr}^{+6}\right)$ & -- & $<18.3$ & $<6.79$ \\
\hline Cyanide $\left(\mathrm{CN}^{-}\right)$ & --- & 11.4 & 6.93 \\
\hline Fluoride $\left(F^{-}\right)$ & 5,500 & 1.26 & 0.467 \\
\hline Hydroxide $\left(\mathrm{OH}^{-}\right)$ & 46,500 & $<1,250$ & $<760$ \\
\hline Nitrate $\left(\mathrm{NO}_{3}{ }^{-}\right)$ & 42,600 & 21,200 & 7,870 \\
\hline Nitrite $\left(\mathrm{NO}_{2}^{-}\right)$ & 12,900 & 29,800 & 11,100 \\
\hline Phosphate $\left(\mathrm{PO}_{4}{ }^{3-}\right)$ & 35,300 & 2.190 & 81.2 \\
\hline Sulfate $\left(\mathrm{SO}_{4}{ }^{2-}\right)$ & 2,800 & 8,530 & 3,170 \\
\hline Radionuclides & $(\mu \mathrm{Ci} / \mathrm{g})$ & $(\mu \mathrm{Ci} / \mathrm{g})$ & (Ci) \\
\hline${ }^{241} \mathrm{Am}$ & --- & 0.395 & 240 \\
\hline${ }^{125} \mathrm{Sb}$ & $-\cdots$ & 0.665 & 404 \\
\hline${ }^{14} \mathrm{C}$ & $-\cdots$ & 0.00133 & 0.809 \\
\hline${ }^{144} \mathrm{Ce} / \mathrm{Pr}$ & $\cdots$ & $<0.174$ & $<1,060$ \\
\hline${ }^{134} \mathrm{Cs}$ & $\ldots$ & $<0.106$ & $<64.4$ \\
\hline
\end{tabular}


Table 5-7. Tank Characterization Report Data in Single-Shell Tank 241-T-105. (3 pages)

\begin{tabular}{|c|c|c|c|}
\hline Analyte & $\begin{array}{c}\text { Historic Tank } \\
\text { Content } \\
\text { Estimate }\end{array}$ & $\begin{array}{c}\text { Tank } \\
\text { Characterization } \\
\text { Report }\end{array}$ & $\begin{array}{l}\text { Total Tank } \\
\text { Inventory }\end{array}$ \\
\hline Radionuclides (continued) & $(\mu \mathrm{Ci} / \mathrm{g})$ & $(\mu \mathrm{Ci} / \mathrm{g})$ & (Ci) \\
\hline${ }^{137} \mathrm{Cs}$ & 4.44 & 55.6 & 33,800 \\
\hline${ }^{60} \mathrm{Co}$ & -- & 2.11 & 1,280 \\
\hline${ }^{154} \mathrm{Eu}$ & --- & 0.737 & 448 \\
\hline${ }^{155}$ Eu & $\cdots$ & 2.11 & 1,280 \\
\hline${ }^{40} \mathrm{~K}$ & -- & 0.340 & 207 \\
\hline${ }^{238} \mathrm{Pu}$ & -- & $<2.45 \mathrm{E}-04$ & $<0.149$ \\
\hline${ }^{239 / 240} \mathrm{Pu}$ & 0.395 & 0.139 & 84.5 \\
\hline${ }^{103} \mathrm{Ru}$ & --- & $<0.164$ & $<99.7$ \\
\hline${ }^{106} \mathrm{Ru} / \mathrm{Rh}$ & --- & $<2.14$ & $<1,300$ \\
\hline${ }^{90} \mathrm{Sr}$ & 3.56 & 281 & $1.71 E+05$ \\
\hline${ }^{99} \mathrm{TC}$ & -- & 0.372 & 226 \\
\hline${ }^{228} \mathrm{Th}$ & $-\cdots$ & $<0.268$ & $<163$ \\
\hline${ }^{3} \mathrm{H}$ & $\ldots$ & 0.0124 & 7.45 \\
\hline Total Alpha & $\cdots$ & 0.278 & 169 \\
\hline Total Beta & -- & 866 & $5.27 E+05$ \\
\hline Physical Properties & --- & $\cdots$ & $\mathrm{kg}$ \\
\hline $\mathrm{pH}$ & --- & 10.9 & --- \\
\hline Specific Gravity & --- & 1.02 & \\
\hline Thermo-gravimetric Analysis & --- & $59.61 \%$ & -- \\
\hline Total Dissolved Solid & --- & $0.193 \%$ & -- \\
\hline Wt \% Solid & -- & $74.9 \%$ & -- \\
\hline Total Solid & -- & $63.5 \%$ & -- \\
\hline Centrifuged Solid & -- & $97 \%$ & -- \\
\hline Residual Solid & -- & $52.72 \%$ & -- \\
\hline Density & $1.30 \mathrm{~g} / \mathrm{mL}$ & $1.64 \mathrm{~g} / \mathrm{mL}$ & --- \\
\hline TIC & $-\cdots$ & $7,660 \mu \mathrm{g} / \mathrm{g}$ & $4,660 \mathrm{~kg}$ \\
\hline TOC & $\ldots$ & $4,130 \mu \mathrm{g} / \mathrm{g}$ & $2,510 \mathrm{~kg}$ \\
\hline
\end{tabular}




\subsection{ANALYTICAL RESULTS INTERPRETATION}

\subsection{TANK WASTE PROFILE}

i

Examination of the analytical results reveals that the waste in Tank 241-T-105 is heterogeneous, indicating that the nature and sources of the waste were very different. A general waste profile based on assessment of the fill history is presented in Figure 6-1. The waste is approximately $74 \%$ solids, and the following elements and anions were present at concentrations exceeding $1000 \mu \mathrm{g} / \mathrm{g}: \mathrm{Al}, \mathrm{Bi}, \mathrm{Ca}, \mathrm{Fe}, \mathrm{Mg}, \mathrm{Mn}, \mathrm{Si}, \mathrm{Na}, \mathrm{U}$, carbonate, nitrate, nitrite, phosphorous/phosphate, and sulfur/sulfate. The major radioactive constituents were ${ }^{137} \mathrm{Cs}$ and ${ }^{90} \mathrm{Sr}$.

\subsection{WASTE SUMMARY AND CONDITIONS}

\subsubsection{Tank Homogeneity Observations}

The hot cell chemists' visual observations of the waste are given in Table 6-1 (Kocher, 1993). It is immediately apparent the waste is heterogeneous, varying both horizontally and vertically. In the horizontal plane, the first segments of each core vary in consistency, ranging from a muddy texture to a brittle and crumbly texture. The color also differs between the first segments in core 53 and 54 . The second segments of each core also contrast. One is almost entirely composed of solids, while the other two are primarily liquids. The characteristics leg density of the waste from cores 53 and 57 vary greatly, although only $3.66 \mathrm{~m}(12$ feet) separate the risers from which they were taken. The statistical analysis of the segment 1 data for cores 53 and 54, presented in detail in Chapter 7, further indicate horizontal variation. Significant differences in analyte concentration were found between the two cores and 24 out of 35 analytes tested.

From the same observations, it is evident that the waste varies vertically. Oniy core 57 remains constant between segments with respect to liquid and solid percentages. Both core 53 and 54 are predominately solid in segment 1 and liquid in segment 2 . Further evidence of vertical waste variance is present in segment 1 of core 54; the color ranges between dark brown and white, all within $48 \mathrm{~cm}$ (19 inches). This color change and consistency variation led to the determination by the hot cell chemist that segment 1 of core 54 was heterogeneous. It is doubtful that the cascade inlet from the previous tank had much influence on the heterogeneity exhibited by this tank, as the nearest riser sampled was over $7.62 \mathrm{~m}$ (25 feet) from the inlet.

\subsubsection{Projected Tank Heat Load}

The amount of heat resulting from radioactivity in the tank was calculated in Table 6-2. Detection limits for some of the analytes were included in the calculation in order to obtain the most conservative estimate possible. The reported heat load was 1,370 Watts. The historical temperature range of the tank is generally between 8.3 and $33.9^{\circ} \mathrm{C}\left(47\right.$ and $\left.93^{\circ} \mathrm{F}\right)$. Since an upper temperature limit is exhibited, it may be concluded that diurnal and annual cycles are the principal factors affecting tank temperature, and that any heat generated from radioactive sources throughout the year is dissipated. 
WHC:SD-WM-ER-369 REV O

Figure 6-1. Waste Profile of Tank 241-T-105.

Waste Profile Tank 241-T-105 Based on Assessment of Historical Data

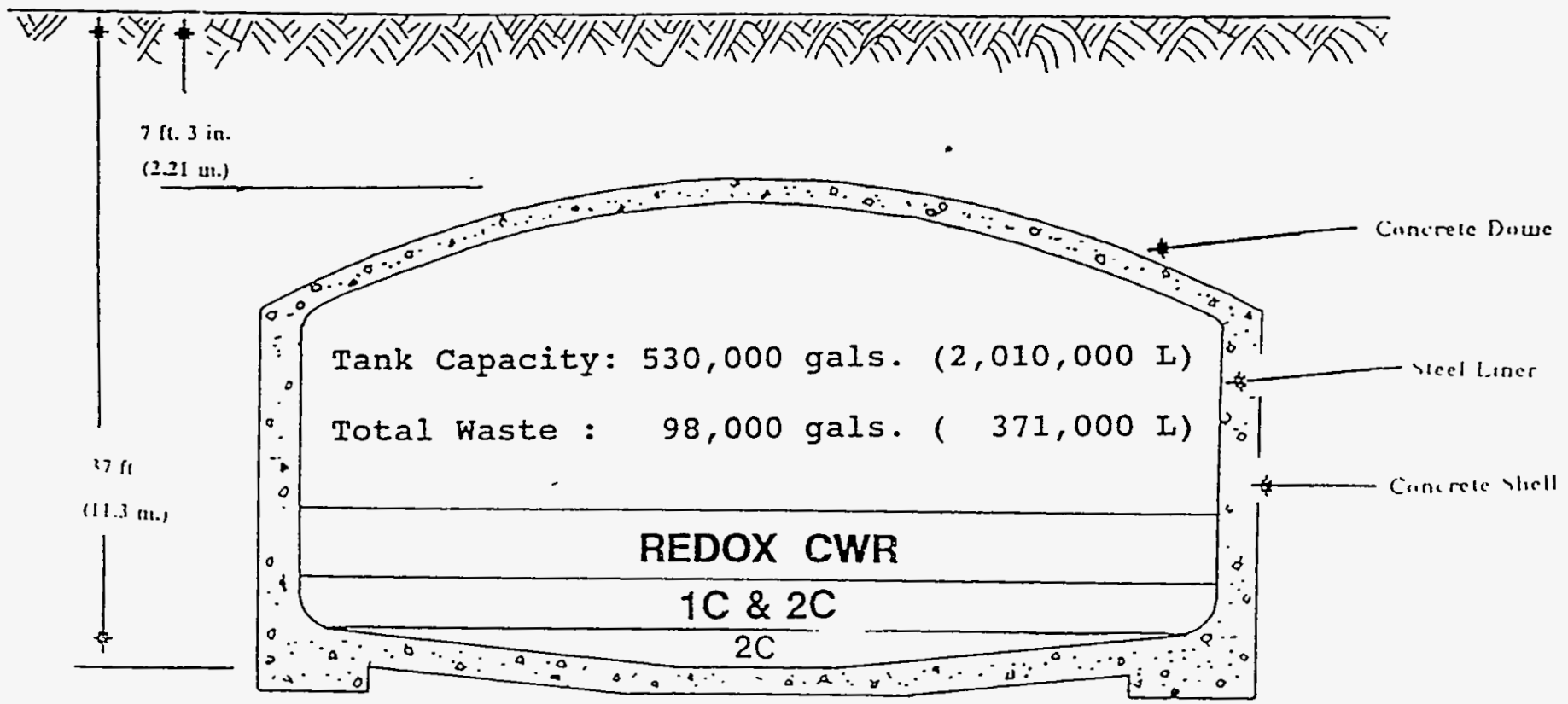

CWR: Cladding Waste - REDOX

1C: $1^{\text {st }}$ cycle decontamination-BiPo ${ }_{4}$ process. often including cladding waste. Held $10 \%$ of Fission Broduct Waste, $1 \%$ of Plutonium.

2C: $2^{\text {nd }}$ cycle decontamination-BiPo 4 process. Supernate often cribbed, $0.1 \%$ of Fission Product Waste, $1 \%$ of Plutonium. 
Table 6-1. Waste Characteristics Comparison.

\begin{tabular}{|l|l|l|l|l|l|l|}
\hline & \multicolumn{2}{|c|}{ Core 53 } & \multicolumn{2}{c|}{ Core 54 } & \multicolumn{2}{c|}{ Core 57 } \\
\hline Character & \multicolumn{1}{|c|}{ Seg. 1 } & Seg. 2 & Seg. 1 & Seg. 2 & Seg. 1 & Seg. 2 \\
\hline Color & brown & --- & $\begin{array}{l}\text { dark brown } \\
\text { to white }\end{array}$ & --- & --- & --- \\
\hline Consistency & $\begin{array}{l}\text { muddy } \\
\text { texture; like } \\
\text { soft, wet clay }\end{array}$ & -- & $\begin{array}{l}\text { smooth, wet } \\
\text { texture; } \\
\text { multiphase } \\
\text { consistency }\end{array}$ & --- & $\begin{array}{l}\text { brittle, } \\
\text { crumbly }\end{array}$ & $\begin{array}{l}\text { brittle, } \\
\text { crumbly }\end{array}$ \\
\hline$\%$ Liquid & 0 & 56 & 5 & 91 & 2 & 0 \\
\hline$\%$ Solid & 18 & $<3$ & 31 & 0 & 98 & 100 \\
\hline $\begin{array}{l}\text { Visual } \\
\text { Homogeneity }\end{array}$ & Yes & No & No & Yes & --- & -- \\
\hline
\end{tabular}

- Information not available.

Table 6-2. Tank 241-T-105 Projected Heat Load.

\begin{tabular}{|l|c|c|}
\hline \multicolumn{1}{|c|}{ Radionuclide } & $\mathbf{C i}$ & Watts \\
\hline${ }^{241} \mathrm{Am}$ & 240 & 7.87 \\
\hline${ }^{125} \mathrm{Sb}$ & 404 & 1.35 \\
\hline${ }^{144} \mathrm{Ce} / \mathrm{Pr}$ & $<1,060$ & $<3.28$ \\
\hline${ }^{134} \mathrm{Cs}$ & $<64.4$ & $<0.657$ \\
\hline${ }^{137} \mathrm{Cs}$ & 33,800 & 160 \\
\hline${ }^{60} \mathrm{Co}$ & 1,280 & 19.7 \\
\hline${ }^{154} \mathrm{Eu}$ & 448 & 4.05 \\
\hline${ }^{155} \mathrm{Eu}$ & 1,280 & 0.792 \\
\hline${ }^{238} \mathrm{Pu}$ & $<0.149$ & $<4.86 \mathrm{E}-03$ \\
\hline${ }^{239 / 240} \mathrm{Pu}$ & 84.5 & 2.58 \\
\hline${ }^{103} \mathrm{Ru}$ & $<99.7$ & $<0.350$ \\
\hline${ }^{106} \mathrm{Ru} / \mathrm{Rh}$ & $<1,300$ & $<12.5$ \\
\hline${ }^{90} \mathrm{Sr}$ & $1.71 \mathrm{E}+05$ & 1,150 \\
\hline $99 \mathrm{Tc}$ & 226 & 0.113 \\
\hline${ }^{228} \mathrm{Th}$ & $<163$ & $<5.23$ \\
\hline Watts & & 1,370 \\
\hline & & \\
\hline
\end{tabular}


WHC-SD-WM-ER-369 REV O

\subsection{PROGRAM ELEMENT SPECIFIC ANALYSES}

The sampling and analysis of Hanford Site waste tanks are driven by the need to satisfy the characterization requirements of the various Tank Waste Remediation System (TWRS) program elements. These characterization needs are summarized in the TWRS Tank Waste Analysis Plan (Bell, 1994) and implemented and documented through the Data Quality Objective process, as expressed in a series of program specific Data Quality Objective documents.

This Tank Characterization Report is the final step in the characterization of Tank 241$T-105$. According to the process and issue based data requirements, the inventory estimates and waste properties contained in this report can be applied to the data requirements of the various program elements. Contained in Table 6-3 is a summary of which program data needs are fulfilled through this characterization of the waste in Tank 241-T-105, based on a review of the stated sampling and analysis requirements. In the future, the applicability of Tank Characterization Report results to each TWRS program element will be documented in tank specific Tank Characterization Plans, prior to the tank sampling. Comparison to established limits of concern for selected analytes can be made by referring to the Tank Characterization Reference Guide (De Lorenzo et al., 1994)

Table 6-3. Applicability of Characterization Information to the Data Needs of the TWRS Program Elements. (2 pages)

\begin{tabular}{|l|c|}
\hline \multicolumn{1}{|c|}{ Data Quality Objective } & $\begin{array}{c}\text { Applicability to Characterization } \\
\text { of Tank 241-T-105 }\end{array}$ \\
\hline Tank Safety Screening & applies \\
\hline Ferrocyanide Safety Issue & does not apply \\
\hline Flammable Gas Tanks Crust Burn Issue & does not apply \\
\hline Flammable Gas Tank & not completed \\
\hline Waste Compatibility & does not apply \\
\hline Organic Fuel Rich Tank & does not apply \\
\hline Rotary Core Vapor Sampling & does not apply \\
\hline Evaporator Operations & not completed \\
\hline Process Control & not completed \\
\hline Waste Tank Retrieval & not completed \\
\hline Waste Tank Pretreatment & not completed \\
\hline High-Level Waste Immobilization & not completed \\
\hline Low-Level Waste Immobilization & not completed \\
\hline Solid, Low-Level Waste Disposal & not completed \\
\hline RCRA Part B Permit Application & not completed \\
\hline
\end{tabular}


Table 6-3. Applicability of Characterization Information to the Data Needs of the TWRS Program Elements. (2 pages)

\begin{tabular}{|l|c|}
\hline \multicolumn{1}{|c|}{ Data Quality Objective } & $\begin{array}{c}\text { Applicability to Characterization } \\
\text { of Tank 241-T-105 }\end{array}$ \\
\hline Tank C-106 High-Heat Safety Issue & does not apply \\
\hline Organic Layer Sampling of Tank C-103 & does not apply \\
\hline
\end{tabular}

1 The sampling requirement for the Safety Screening Data Quality Objective (Babad, 1994) calls for both vertical waste samples and a vapor space sample. The sampling and analysis of Tank 241-T-105 support full characterization of the waste in the tank; vapor space sampling or characterization was not conducted as part of this activity.

applies - The data needs expressed in this Data Quality Objectives document are fulfilled through this characterization report.

does not apply - The data needs expressed in this Data Quality Objectives document do not apply to the waste in Tank 241-T-105.

not complete - At the date of preparation of this report, this Data Quality Objectives document has not yet been completed. 


\subsection{STATISTICAL INTERPRETATION}

\subsection{MASS AND CHARGE BALANCE}

\subsubsection{Introduction}

The principle objective in performing a mass and charge balance is to determine if the measurements are self-consistent. In calculating the balances, only analytes detected at a concentration of $1000 \mu \mathrm{g} / \mathrm{g}$ or greater were considered. The chemical compounds assumed to be present in the waste and the corresponding analytes are shown in Table 7-1.

Mass and charge balance results for Tank 241-T-105 are reported in Table 7-2. The identity of the analytes is shown in the left-most column. The next three columns list the raw analytical data. Mass ratios of the assumed species to the corresponding analytes are used to convert from analyte concentrations to assumed-species concentrations which are shown in the last three columns.

Table 7-1. Assumed Species if Different than Analyte.

\begin{tabular}{|c|c||c|c|}
\hline Analyte & Assumed Species & Analyte & Assumed Species \\
\hline $\mathrm{Al}$ & $\mathrm{Al}(\mathrm{OH})_{3}$ & $\mathrm{P}$ & $\left(\mathrm{PO}_{4}\right)^{3-}$ \\
\hline $\mathrm{Bi}$ & $\mathrm{Bi}^{3+}$ & $\mathrm{S}$ & $\left(\mathrm{SO}_{4}\right)^{2-}$ \\
\hline $\mathrm{Ca}$ & $\mathrm{CaO}$ & $\mathrm{Si}$ & $\mathrm{SiO}_{2}$ \\
\hline $\mathrm{Fe}$ & $\mathrm{FeO}(\mathrm{OH})$ & $\mathrm{U}$ & $\mathrm{U}_{3} \mathrm{O}_{8}$ \\
\hline $\mathrm{Mg}$ & $\mathrm{MgO}$ & $\mathrm{TIC}$ & $\left(\mathrm{CO}_{3}\right)^{2-}$ \\
\hline $\mathrm{Mn}$ & $\mathrm{MnO}_{2}$ & $\mathrm{TOC}$ & $\mathrm{C}_{2} \mathrm{H}_{3} \mathrm{O}_{2}^{-}$ \\
\hline $\mathrm{Na}$ & $\mathrm{Na}^{+}$ & & \\
\hline
\end{tabular}

The raw analytical data, taken from Tables A-1, A-4, and A-2 of Appendix $A$, are the mean values for a given analyte. Among the analytes listed in Table $\mathrm{A}-1$, only $\mathrm{Al}, \mathrm{Bi}, \mathrm{Ca} \mathrm{Fe}$, $\mathrm{Mg}, \mathrm{Mn}, \mathrm{Na}, \mathrm{P}, \mathrm{S}, \mathrm{Si}$, and $\mathrm{U}$ had concentrations greater than $1000 \mu \mathrm{g} / \mathrm{g}$. The concentrations for the two carbon-containing anions, Total Inorganic Carbon (TIC) which is assumed to be $\mathrm{CO}_{3}{ }^{2-}$ and Total Organic Carbon (TOC) which is assumed to be $\mathrm{C}_{2} \mathrm{H}_{3} \mathrm{O}_{2}^{-}$are taken from Table $\mathrm{A}-4$ and are the mean values of four different samples. The concentrations of the remaining anions, $\mathrm{NO}_{3}{ }^{-}, \mathrm{NO}_{2}{ }^{-}, \mathrm{PO}_{4}{ }^{3-}$, and $\mathrm{SO}_{4}{ }^{2-}$, are taken from Table $\mathrm{A}-2$.

\subsubsection{Calculations and Discussion}

The analytes were assumed to be present in their most common hydroxide or oxide forms. For example, aluminum hydroxide, $\mathrm{Al}(\mathrm{OH})_{3}$, is taken as the assumed species for the aluminum analyte. Although smaller concentrations of other forms of aluminum such as aluminosilicate are probably also present in the waste, they are not included in order to keep the mass-charge balance calculations simple and consistent. 
Table 7-2. Tank 241-T-105 Mass and Charge Balance.

\begin{tabular}{|c|c|c|c|c|c|c|}
\hline Analyte & \multicolumn{3}{|c|}{$\begin{array}{l}\text { Concentrations }(\mu \mathrm{g} / \mathrm{g}) \\
\text { from Analytical Data }\end{array}$} & \multicolumn{3}{|c|}{$\begin{array}{c}\text { Concentrations }(\mu \mathrm{g} / \mathrm{g}) \text { from } \\
\text { Assumed Species }\end{array}$} \\
\hline Method & ICP.w & ICP.a & ICP.f & ICP.w & ICP.a & ICP.f \\
\hline Ál & & 92,400 & 95,100 & & 267,000 & 275,000 \\
\hline $\mathrm{Bi}$ & & 1,330 & 1,220 & & 1,330 & 1,220 \\
\hline $\mathrm{Ca}$ & & 1,420 & 3,670 & & 1,990 & 5,130 \\
\hline $\mathrm{Fe}$ & & 27,300 & 33,100 & & 43,400 & 52,700 \\
\hline $\mathrm{Mg}$ & & 1,060 & 1,100 & & 1.760 & 1,820 \\
\hline $\mathrm{Mn}$ & & 11,600 & 10,400 & & 18,400 & 16,500 \\
\hline $\mathrm{Na}$ & 49,500 & 56,300 & 49,200 & 49,500 & 56,300 & 49,200 \\
\hline$P$ & & 1,490 & 1,530 & & 4,570 & 4,690 \\
\hline$S$ & 2,760 & 2,610 & 2,620 & 8,260 & 7,810 & 7,840 \\
\hline $\mathrm{Si}$ & & 1,160 & 6,980 & & 2,480 & 14,900 \\
\hline Method & \multicolumn{3}{|c|}{ Laser Fluorimetry } & \multicolumn{3}{|c|}{ Laser Fluorimetry } \\
\hline$U$ & & & 9,120 & & & 10,800 \\
\hline Method & \multicolumn{3}{|c|}{ Coulometry } & \multicolumn{3}{|c|}{ Coulometry } \\
\hline TIC & 4,890 & & & 24,500 & & \\
\hline TOC & 3,420 & & & 8,410 & & \\
\hline Method & IC.w & & & IC.w & & \\
\hline$\left(\mathrm{NO}_{3}\right)^{-}$ & 21,200 & & & 21,200 & & \\
\hline$\left(\mathrm{NO}_{2}\right)^{-}$ & 29,800 & & & 29,800 & & \\
\hline$\left(\mathrm{PO}_{4}\right)^{3-}$ & 2,190 & & & 2,190 & & \\
\hline$\left(\mathrm{SO}_{4}\right)^{2-}$ & 8,530 & & & 8,530 & & \\
\hline $1+1$ & & & & 2,150 & 2,450 & 2,140 \\
\hline$(-1)$ & & - & & 2,200 & 2,200 & 2,200 \\
\hline $\begin{array}{l}\text { Charge Balance } \\
(+1 /(-)\end{array}$ & & & & 0.98 & 1.11 & 0.97 \\
\hline$[x]$ & & & & & 489,000 & 524,000 \\
\hline $\begin{array}{l}\% \text { Water (from } \\
\text { TGA) }\end{array}$ & & & & & 43.75 & 43.75 \\
\hline $\begin{array}{l}\text { Mass } \\
\text { Balance (\%) }\end{array}$ & & & & & 92.6 & 96.1 \\
\hline
\end{tabular}

$(+)=$ Total cations (microequivalents)

$(-)=$ Total anions (microequivalents)

$[\mathrm{x}]=$ Total analyte concentration 
Phosphorus is determined by ICP and phosphate is determined by IC. Assuming that all the phosphorus is present as phosphate and converting the phosphorus concentration accordingly yields concentrations of $4570 \mu \mathrm{g} / \mathrm{g}$ for the acid-digested sample and $4690 \mu \mathrm{g} / \mathrm{g}$ for the fusion-digested sample, that are approximately twice the IC value for phosphate of $2190 \mu \mathrm{g} / \mathrm{g}$. This indicates that approximately half of the phosphate is water-soluble and can be accounted for as $\mathrm{Na}_{3} \mathrm{PO}_{4}$ while half of it is water-insoluble and can be accounted for as $\mathrm{BiPO}_{4}$.

Sulfur is considered to be present as the sulfate ion, and appears to be completely water-soluble. The sulfate concentrations calculated from the ICP.w, ICP.a, and ICP.f values for sulfur are $8260,7810,7840 \mu \mathrm{g} / \mathrm{g}$, respectively. These values are in good agreement with the IC.W sulfate concentration of $8530 \mu \mathrm{g} / \mathrm{g}$.

- The charge balance is the ratio of total cations (microequivalents) to total anions (microequivalents). Since the anion data are obtained only from water-digest ion chromatography (IC.w), the anions to be considered are those that will form water-soluble species.

Total cations (microequivalents) $=\left[\mathrm{Na}^{+}\right] / 23.0$

The sodium concentrations from water-digest Inductively Coupled Plasma (ICP.W), acid-digest ICP (ICP.a), and fusion-digest ICP (ICP.f) are 49500, 56300, and $49200 \mu \mathrm{g} / \mathrm{g}$, respectively. Thus, the resulting total cations values are 2150,2450 , and 2140 microequivalents, respectively.

Total anions (microequivalents)

$$
\begin{aligned}
& =\left[\mathrm{CO}_{3}{ }^{2-}\right] / 30.0+\left[\mathrm{C}_{2} \mathrm{H}_{3} \mathrm{O}_{2}{ }^{-}\right] / 59.0+\left[\mathrm{NO}_{3}{ }^{-}\right] / 62.0+\left[\mathrm{NO}_{2}{ }^{-}\right] / 46.0+\left[\mathrm{PO}_{4}{ }^{3-}\right] / 31.7+ \\
& {\left[\mathrm{SO}_{4}{ }^{2-}\right] / 48.0} \\
& =24500 / 30.0+8410 / 59.0+21200 / 62.0+29800 / 46.0+2190 / 31.7+8530 / 48.0 \\
& =2200
\end{aligned}
$$

The charge balances obtained from using the three ICP.W, ICP.a, and ICP.f sodium concentrations in conjunction with the set of TIC, TOC, and IC.W anion concentrations are $0.98,1.11$, and 0.97 , respectively.

The mass balance can be calculated from the formula below. The factor 0.0001 is the conversion factor from $\mu \mathrm{g} / \mathrm{g}$ to weight percent. The ICP.a and ICP.f values for phosphate, 4570 and $4690 \mu \mathrm{g} / \mathrm{g}$, as well as the ICP. a and ICP.f values for sulfate, 7810 and $7840 \mu \mathrm{g} / \mathrm{g}$, which include both water-soluble and water-insoluble forms of phosphate and sulfate, are used in calculating the total analyte concentrations instead of the corresponding IC values.

$$
\begin{aligned}
& \text { Mass balance }=\% \text { Water }+0.0001 \times\{\text { Total Analyte Concentration }\} \\
& =\% \text { Water }+0.0001 \times\left\{\left[\mathrm{Al}(\mathrm{OH})_{3}\right]+\left[\mathrm{Bi}^{3+}\right]+[\mathrm{CaO}]+[\mathrm{FeO}(\mathrm{OH})]+[\mathrm{MgO}]+\left[\mathrm{MnO}_{2}\right]+\right. \\
& \left.\left[\mathrm{Na}^{+}\right]+\left[\left(\mathrm{PO}_{4}\right)^{3-}\right]+\left[\left(\mathrm{SO}_{4}\right)^{2-}\right]+\left[\mathrm{SiO}_{2}\right]+\left[\mathrm{U}_{3} \mathrm{O}_{8}\right]+\left[\left(\mathrm{CO}_{3}\right)^{2-}\right]+\left[\mathrm{C}_{2} \mathrm{H}_{3} \mathrm{O}_{2}^{-}\right]+\left[\left(\mathrm{NO}_{3}\right)^{-}\right]+\left[\left(\mathrm{NO}_{2}\right)^{-}\right]\right\}
\end{aligned}
$$

The mean \% water obtained from thermogravimetric analysis reported in Table A-4 of Appendix $A$ is 59.61. However, this value also includes data for segment 2 of core 53 sample. Only segment 1 of cores 53 and 54 should be taken into account since these are the samples considered in calculating the total analyte concentration. Thus, a more appropriate mean $\%$ water value would be 43.75 . The total analyte concentration calculated from the ICP.a analyte concentrations, the TIC and TOC concentrations, and the IC.W concentrations 
for $\left(\mathrm{NO}_{3}\right)^{-}$and $\left(\mathrm{NO}_{2}\right)^{-}$is 489,000 . Similarly, the ICP.f analyte concentrations, the TIC and TOC concentrations, and the IC.w concentrations for $\left(\mathrm{NO}_{3}\right)^{-}$and $\left(\mathrm{NO}_{2}\right)^{-}$yield a total analyte concentration of 524,000 . The mass balances resulting from these total analyte concentrations are $92.6 \%$ and $96.1 \%$, respectively.

In summary, the above calculations yield excellent (close to 1.00 for charge balance and $100 \%$ for mass balance) charge balance values ranging from 0.97 to 1.11 and mass balance values ranging from 92.6 to $96.1 \%$. Although these charge and mass balances are obtained from mean concentrations of several samples, they are in reasonable agreement with the mass and charge balance analysis carried out by Dan Herting of the WHC Process Chemistry Laboratories (WHC, 1993) using two separate data sets from the first segment of cores 53 and 54 . This analysis is also included in this document for comparison as Appendix B.

\subsection{STATISTICAL ANALYSIS}

As mentioned in section 3.0, two core samples were taken from Tank 241-T-105. Homogenized primary and duplicate sample results were obtained from each core for each analyte. Since insufficient liquid was recovered from segment 2 of both cores, the statistical analysis in this section was conducted only on the segment 1 "solid" material. No core composites were made on any of the tank material recovered due to lack of sample.

Analysis of variance (ANOVA) models were fit to the data for all analytes that did not have any "less than values" (non-detects) (Jensen, 1994). From a quality of data perspective, it is desirable that the ANOVA model be applied to analyte concentrations greater than 10 times the detection limit. However, when this goal was not achievable, the ANOVA models were fit using all of the data whether it was above or below a particular limit. To warn the reader of potential detection limit problems, the analytes in Table 7-3 are denoted by a "\#" or "\#\#" whenever a concentration is less than 3 times or 10 times the detection limit, respectively.

Using the hierarchical structure of the core composite data, estimates of the spatial variance $\left(\sigma^{2}(S)\right)$, and the analytical measurement variance $\left(\sigma^{2}(A)\right)$ were obtained for each analyte. The spatial variance is a measure of the variability between cores, while the analytical measurement variance measures the difference in results between the primary and duplicate samples.

To test the significance of the variance components, an ANOVA was calculated (Jensen, 1994). The mean square error terms in the ANOVA table was used to test the spatial variability. The estimate of spatial variability for each analyte along with the $p$-values (significance level) are given in Table 7-3. A p-value less than 0.05 indicates that $\sigma^{2}(S)$ is significantly different from zero at the $a=0.05$ significance level.

The p-values from the tests on $\sigma^{2}(S)$ were statistically significant for 24 out of 35 analytes tested. The 24 analytes in which differences in concentrations were found represent over $95 \%$ of the "solid" tank contents. In order to assess the magnitude of the concentration differences for these 24 analytes, the highest mean from the two duplicate pairs analyzed was divided by the lowest mean. The results for americium-241 were largest, with the highest mean being 6.0 times the value of the lowest mean. The smallest mean difference was 1.3 for strontium. The average magnitude of mean difference for all 24 analytes was 2.6. 
Table 7-3. Variance Component Estimates.. (2 pages)

\begin{tabular}{|c|c|c|c|}
\hline Analyte & $\sigma^{2}(S)$ & $\begin{array}{c}\text { Test: } \\
\sigma^{2}(S)=0 \\
\text { p-value }\end{array}$ & $\sigma^{2}(A)$ \\
\hline${ }^{1}$ ICP.f.Ag\#\# & $1.06 E+03$ & $0.008^{*}$ & $1.63 E+01$ \\
\hline ICP.f.AI & $6.24 E+09$ & $0.000^{*}$ & $4.42 E+06$ \\
\hline${ }^{2} \mathrm{ICP} . \mathrm{a} . \mathrm{Bi}$ & $7.60 E+03$ & 0.198 & $5.83 E+03$ \\
\hline${ }^{3}$ ICP.w.B & $8.13 E+02$ & 0.330 & $2.60 E+03$ \\
\hline ICP.f.Ca & $1.31 E+06$ & 0.342 & $5.00 E+06$ \\
\hline ICP.f.Cd\#\# & $2.87 E+01$ & $0.018^{*}$ & $1.11 \mathrm{E}+00$ \\
\hline ICP.f.Ce\# & $2.11 E+03$ & $0.032^{*}$ & $1.45 E+02$ \\
\hline ICP.a.Cr & $9.68 E+04$ & $0.011^{*}$ & $2.26 E+03$ \\
\hline ICP.f.Fe & $9.01 E+07$ & 0.161 & $4.79 E+07$ \\
\hline ICP.f.Li\# & 6.79E-01 & 0.152 & 3.31E-01 \\
\hline ICP.a.K & $1.56 E+04$ & 0.080 & $3.11 E+03$ \\
\hline ICP.f.Mg & $4.15 E+04$ & $0.028^{*}$ & $2.46 \mathrm{E}+03$ \\
\hline ICP.a.Mn & $1.35 E+08$ & $0.014^{*}$ & $3.81 E+06$ \\
\hline ICP.w.Mo & $3.38 E+02$ & $0.000^{*}$ & 2.00E-01 \\
\hline ICP.a.Na & $2.87 E+08$ & $0.045^{*}$ & $2.88 \mathrm{E}+07$ \\
\hline ICP.a.Ni & $4.49 E+02$ & $0.033^{*}$ & $3.21 E+01$ \\
\hline ICP.f.P & $3.55 E+05$ & $0.006^{*}$ & $4.53 E+03$ \\
\hline ICP.a.Pb & $1.38 E+05$ & $0.016^{*}$ & $4.69 E+03$ \\
\hline ICP.w.S & $9.74 E+05$ & $0.006^{*}$ & $1.11 E+04$ \\
\hline ICP.f.Si & $2.23 E+05$ & 0.384 & $2.00 E+06$ \\
\hline ICP.a.Sr & $6.88 E+02$ & $0.044^{*}$ & $6.85 E+01$ \\
\hline ICP.f.Ti & $3.48 E+04$ & 0.129 & $1.31 E+04$ \\
\hline ICP.f.Zr & $9.52 E+02$ & 0.230 & $9.97 E+02$ \\
\hline $\mathrm{Hg}$ & $3.25 E+02$ & $0.026^{*}$ & $1.79 E+01$ \\
\hline $\mathrm{CN}^{-}$ & $1.49 E+01$ & 0.358 & $7.46 E+01$ \\
\hline${ }^{4}$ IC.W.Cl & $2.35 E+04$ & $0.001^{*}$ & $4.25 E+01$ \\
\hline IC.W.NO ${ }_{2}^{-}$ & $1.28 E+08$ & $0.003^{*}$ & $8.13 E+05$ \\
\hline IC.W. $\mathrm{NO}_{3}^{-}$ & $6.49 E+07$ & $0.002^{*}$ & $2.50 E+05$ \\
\hline IC.W. $\mathrm{PO}_{4}^{-3}$ & $3.55 E+05$ & $0.005^{*}$ & $3.63 E+03$ \\
\hline IC.w.SO ${ }_{4}^{-2}$ & $1.06 \mathrm{E}+07$ & $0.001^{*}$ & $2.41 E+04$ \\
\hline${ }^{5} \mathrm{GEA} \cdot{ }^{241} \mathrm{Am}$ & $7.35 \mathrm{E}-01$ & $0.020^{*}$ & $3.16 E-02$ \\
\hline
\end{tabular}


Table 7-3. Variance Component Estimates. (2 pages)

\begin{tabular}{|l|c|c|c|}
\hline \multicolumn{1}{|c|}{ Analyte } & $\sigma^{2}(\mathrm{~S})$ & $\begin{array}{c}\text { Test: } \\
\sigma^{2}(\mathrm{~S})=0 \\
\text { p-value }\end{array}$ & $\sigma^{2}(\mathrm{~A})$ \\
\hline GEA. ${ }^{137} \mathrm{Cs}$ & $1.43 \mathrm{E}+02$ & $0.000^{*}$ & $5.00 \mathrm{E}-03$ \\
\hline GEA. ${ }^{60} \mathrm{Co}$ & $3.91 \mathrm{E}-04$ & 0.103 & $1.08 \mathrm{E}-04$ \\
\hline GEA. ${ }^{154} \mathrm{Eu}$ & $2.89 \mathrm{E}+00$ & $0.018^{*}$ & $1.08 \mathrm{E}-01$ \\
\hline GEA. ${ }^{155} \mathrm{Eu}$ & $4.34 \mathrm{E}+00$ & $0.020^{*}$ & $1.79 \mathrm{E}-01$ \\
\hline
\end{tabular}

1: ICP.f = Inductively Coupled Plasma, $\mathrm{KOH} /$ Nickel fusion dissolution

2: ICP.a = Inductively Coupled Plasma, acid digestion

3: ICP.W = Inductively Coupled Plasma, water leach

4: IC = Ion Chromatography, water digestion

5: GEA = Gamma Energy Analysis

${ }^{*}$ : = significant at the $a=0.05$ level

$\#:=$ less than three times the detection limit

$\#$ \#: = less than ten times the detection limit

Therefore, the "solid" portion of the tank contents appears to be generally heterogeneous, in addition to the multiple phases already known to exist in the tank (liquid, "muddy", crusty).

\subsection{ANALYTICAL ERROR ESTIMATION}

An attempt is always made to quantify the different sources of error possible during the chemical analysis of a sample. When these errors are summarized, they give a strong indication of data reliability. If one or more of the error estimates are outside the acceptable limits, the accuracy of the concentration estimate is drawn into question. Possible sources of error are sample contamination, matrix interferences, analytical method error, and poor instrument calibration.

Analytical error is composed of two parts, random and systematic. Table 7-4 gives both the analytical and systematic error estimates for Tank 241-T-105, organized by analyte.

\subsubsection{Systematic Analytical Error}

Systematic error estimates are determined from the analysis of reference standards or spike recoveries. Reference standards are samples used to estimate the accuracy of the analytical method, and are analyzed in conjunction with the duplicate samples. They are prepared by adding a known amount of a particular analyte at a concentration other than that used for equipment calibration. The laboratory measurement control system has set a quality control criterion of no standard run in conjunction with the analytical samples being larger than three times the historical results. These values are listed in column 4 of Table 7-4. 
Table 7-4. Measurement Error Estimates. (2 pages)

\begin{tabular}{|c|c|c|c|c|}
\hline \multirow{2}{*}{ Analyte } & \multicolumn{2}{|c|}{$\begin{array}{c}\text { Analytical error estimate - } \\
1 \text { RSD }(\%) \\
\end{array}$} & \multicolumn{2}{|c|}{$\begin{array}{l}\text { Systematic error estimate - } \\
\quad 1 \text { RSD }(\%)\end{array}$} \\
\hline & $\begin{array}{l}\text { From sample } \\
\text { results }\end{array}$ & $\begin{array}{c}\text { From standard } \\
\text { results }\end{array}$ & $\begin{array}{l}\text { From standard } \\
\text { results }\end{array}$ & $\begin{array}{c}\text { From spike } \\
\text { analyses }\end{array}$ \\
\hline Aluminum & 3.2 & 2.1 & 47 & 182 \\
\hline Bismuth & 6.1 & 9.2 & 16 & 3.5 \\
\hline Boron & 15 & 5.0 & 6.9 & 4.9 \\
\hline Cadmium & 6.9 & 3.5 & 0.2 & 1.5 \\
\hline Calcium & 61 & 3.2 & 0.5 & 16 \\
\hline Chromium & 1.6 & 3.6 & 2.5 & 1.3 \\
\hline Iron & 21 & 2.5 & 2.6 & 29 \\
\hline Lead & 7.9 & 3.4 & 1.5 & 5.3 \\
\hline Mercury & 18 & 7.2 & 6.2 & 16 \\
\hline Magnesium & 4.5 & 2.7 & 0.5 & 2.3 \\
\hline Manganese & 3.8 & 2.8 & 5.1 & 26 \\
\hline Molybdenum & 1.3 & NA & 4.4 & 4.7 \\
\hline Nickel & 6.9 & 2.9 & 5.1 & 1.4 \\
\hline Phosphorus & 4.4 & 6.1 & 8.0 & 7.7 \\
\hline Potassium & 21 & 3.2 & 2.5 & 12 \\
\hline Silicon & 20 & 5.9 & 7.9 & 8.6 \\
\hline Silver & 8.7 & 3.8 & 2.4 & 3.8 \\
\hline Sodium & 3.0 & 1.7 & 6.7 & 52 \\
\hline Strontium & 4.2 & 1.9 & 6.6 & 1.0 \\
\hline Sulfur & 3.8 & 2.6 & 1.2 & 12 \\
\hline Titanium & 50 & 3.2 & 2.4 & 2.0 \\
\hline Uranium & 8.2 & 6.1 & 1.1 & 6.8 \\
\hline Zirconium & 27 & 2.7 & 7.9 & 7.7 \\
\hline Chlorine & 1.6 & 3.9 & 2.8 & 1.2 \\
\hline Cyanide & 76 & 2.5 & 1.5 & 14 \\
\hline Nitrate & 2.4 & 4.1 & 5.2 & 4.3 \\
\hline Nitrite & 3.0 & 3.8 & 4.7 & 6.5 \\
\hline Phosphate & 2.8 & 3.5 & 2.1 & 3.0 \\
\hline Sulfate & 1.8 & 2.9 & 4.6 & 0.8 \\
\hline${ }^{241} \mathrm{Am}$ & 21 & 10 & NA & NA \\
\hline${ }^{137} \mathrm{Cs}$ & 31 & 2.5 & 5.0 & NA \\
\hline${ }^{60} \mathrm{Co}$ & 27 & 2.6 & 0.0 & NA \\
\hline
\end{tabular}


Table 7-4. Measurement Error Estimates. (2 pages)

\begin{tabular}{|l|c|c|c|c|}
\hline \multirow{2}{*}{ Analyte } & \multicolumn{2}{|c|}{$\begin{array}{c}\text { Analytical error estimate - } \\
\text { 1 RSD (\%) }\end{array}$} & \multicolumn{2}{c|}{$\begin{array}{c}\text { Systematic error estimate - } \\
\text { 1 RSD (\%) }\end{array}$} \\
\cline { 2 - 5 } & $\begin{array}{c}\text { From sample } \\
\text { results }\end{array}$ & $\begin{array}{c}\text { From standard } \\
\text { results }\end{array}$ & $\begin{array}{c}\text { From standard } \\
\text { results* }\end{array}$ & $\begin{array}{c}\text { From spike } \\
\text { analyses }\end{array}$ \\
\hline${ }^{155} \mathrm{Eu}$ & 20 & NA & NA & NA \\
\hline${ }^{239 / 240} \mathrm{Pu}$ & 9.1 & NA & 4.6 & 17 \\
\hline${ }^{90} \mathrm{Sr}$ & 5.3 & 6.7 & 3.6 & 9.3 \\
\hline${ }^{3} \mathrm{H}$ & 11 & 11 & 3.2 & 21 \\
\hline $\begin{array}{l}\text { Total Inorganic } \\
\text { Carbon (TIC) }\end{array}$ & 3.6 & 4.1 & 3.8 & 1.2 \\
\hline $\begin{array}{l}\text { Total Organic } \\
\text { Carbon (TOC) }\end{array}$ & 5.4 & 3.4 & 2.3 & 4.4 \\
\hline
\end{tabular}

* Calculated from the laboratory measurement control system standards analyzed in conjunction with the samples.

NA: Information not available.

Matrix spikes are used to estimate the bias of the analytical method due to matrix interferences. Spike samples are prepared by splitting a sample into two aliquots and adding a known amount of a particular analyte to one aliquot to calculate a percent recovery. The quality control criterion for spikes is $100 \pm 25 \%$ recovery. The numbers listed in column 5 of Table 7-4 are the relative standard deviations (RSD) of the spikes for each analyte.

For most of the analytes the differences between the two estimates were not large (Table 7-4). Only six had one or more spikes that were outside the $100 \pm 25 \%$ limits. Iron, mercury, manganese, and tritium each had one out of two spikes outside these limits, while sodium had both spikes outside and aluminum had two out of four outside these limits. Four of these elements were metals found in relatively high concentrations in the tank. Spike failures for major elements in general are frequently caused by a high element concentration in the sample. When the added spike concentration is insignificant compared to the concentration present in the sample, a failure usually occurs. Also, the standard results for aluminum, sodium, and strontium (column 4 data) exceeded the criteria of three times the historical results (column 3 data), which may indicate a problem with the analytical method.

\subsubsection{Random Analytical Error}

The random analytical error can be estimated from the historical base of reference standards or from the analytical results (variation between duplicate samples). These reference standards are determined the same way as the ones for systematic error, but are typically derived from 50 samples and updated every year (column 3). To determine the error due to the analytical results of the duplicate samples (column 2), a relative percent difference (RPD) is calculated for each duplicate pair. The RPD is a measure of variability and is defined as the absolute value of one duplicate minus the other, divided by the mean. An RSD is then calculated by taking the standard deviation of the two or more duplicate pairs and dividing by 
the overall analyte mean. The RSD is a unitless measure of variability and allows the comparison of variation across constituents whose magnitudes may vary widely. The laboratory measurement control system has set the quality control criterion of no RPD being larger than the RSD times three for a given analyte. All data presented in this section were calculated for analytes with detected values only (no "non-detects").

Only four of the analytes listed in Table 7-4 had one RPD value exceeding the criterion of three times the random analytical error from sample results (RSD). Of these four, no problem was detected in the analytical procedure for potassium and strontium-90. Manganese had one spike recovery slightly outside the prescribed limits (section 7.3.1), and the tritium concentration was less than four times the detection limit.

\subsection{DATA VALIDATION FINDINGS}

The primary objective of data validation is to ensure the usability and defensibility of the data produced for the tank. This was accomplished through a detailed examination of the data packages which attempted to verify that proper and acceptable analytical techniques had been applied. Evaluations such as instrument calibration checks, matrix spikes, duplicates, and blank analyses were reviewed, and the corresponding results were compared to relevant quality control criteria. Additionally, the data packages were checked for the correct submission of required deliverables, correct transcription of raw data to the summary forms, and for proper calculation of a number of parameters. Data which failed to satisfy the established quality objectives were qualified as reported in Kocher (1993) and Giamberardini (1993). 


\subsection{RECOMMENDATIONS}

\subsection{SAFETY ISSUES}

Characterization of Single-Shell Tank 241-T-105 supports the classification of the tank as non-Watch List. Given the current tank inventory of fissionable radionuclides and organic or exothermic waste constituents, no credible potential exists for loss of tank integrity or release of radioactivity due to in tank processes. Tank 241-T-105 is within established operating safety requirements as defined by applicable Data Quality Objectives. The tank is sound (Hanlon, 1994), and, excluding salt well pumpings, the waste level has remained stable since 1977 (Welty, 1988). In its current state, Tank 241-T-105 poses no unreasonable risk to personnel, the public, or the environment.

\subsection{FURTHER CHARACTERIZATION NEEDS AND TANK ACTIVITIES}

Characterization of the waste in Tank 241-T-105 has been performed in this report. While the current characterization is extensive, further sampling and analysis of Tank 241-T105 is suggested for the following waste properties:

- Since the waste is strongly heterogeneous, as discussed in Section 6.2.1 and 7.2 , a better understanding of the waste spatial variability and a more accurate assessment of the tank contents could be acquired if at least two more core samples were taken. This request is further justified by the incomplete nature of the core 53 and 54 recoveries. The percent air in core 53, segments 1 and 2 , was $82 \%$ and $41 \%$ respectively. The percent air in core 54, segments 1 and 2 , was $64 \%$ and $9 \%$, respectively. This poor recovery also implies a substantial bias in the sample results that were obtained.

- An analysis of the tank vapor space would allow final resolution of any safety concerns regarding the presence of flammable or noxious fumes. 


\subsection{REFERENCES}

Agnew, S.F., 1994. Hanford Defined Wastes: Chemical and Radionuclide Compositions, WHC-SD-WM-TI-629, Westinghouse Hanford Company, Richland, WA.

Anderson, J.D., 1990. A History of the 200 Area Tank Farms, WHC-MR-0132, Rev. 0, Westinghouse Hanford Company, Richland, WA.

Babad, H., 1994. Tank Safety Screening Data Quality Objective, WHC-SD-WM-004, Westinghouse Hanford Company, Richland, WA.

Bell, K.E., 1994. Tank Waste Remediation System Tank Waste Analysis Plan, WHC-SD-WMPLN-077, Rev. O, Westinghouse Hanford Company, Richland, WA.

Bergmann, L.M., 1991. Single-Shell Tank Isolation Safety Analysis Report, WHC-SD-WMSAR-006, Rev. 2, Westinghouse Hanford Company, Richland, WA.

Conway, J.T., 1993. DNFSB Recommendation 93-5 to the Secretary of the Energy, (Letter 9400070 to H. R. O'Leary, DOE, July 19), Defense Nuclear Safety Board, Washington, D.C.

De Lorenzo, D.S., J.H. Rutherford, D.J. Smith, D.B. Hiller, K.W. Johnson, 1994. Tank Characterization Reference Guide, WHC-SD-WM-TI-648, Los Alamos Technical Associates, Kennewick, WA.

Ecology, 1991. Dangerous Waste Regulations, Washington Administrative Code, 170-303, Washington State Department of Ecology, Olympia, WA.

Ecology, EPA, and DOE, 1993. Hanford Federal Facility Agreement and Consent Order, Washington State Department of Ecology, U.S. Environmental Protection Agency, and U.S. Department of Energy, Olympia, WA.

Fulton, J.C., 1992. Riser Configuration Survey for SSTs, WHC-SD-RE-TI-053, Rev. 8, Westinghouse Hanford Company, Richland, WA.

Giamberardini, K.K., 1993. 222-S Laboratories Single-Shell Tank Waste Characterization, Tank T-105 Core 57 Data Package, WHC-SD-WM-DP-040, Rev. 0, Westinghouse Hanford Company, Richland, WA.

Hanlon, B.L., 1994. Tank Farm Surveillance and Waste Status Summary Report for March 1994, WHC-EP-0182-72, Westinghouse Hanford Company, Richland, WA.

Husa, E.I., R.E. Raymond, R.K. Welty, S.M. Griffith, B.M. Hanlon, R.R. Rios, and N.J. Vermeulen, 1993. Hanford Site Waste Storage Tank Information Notebook, WHC-EP-0625, Westinghouse Hanford Company, Richland, WA.

Jungfleisch, F.M., 1984a. TRAC: Preliminary Estimation of the Waste Inventories in Hanford Tanks Through 1980, Transaction File, SD-WM-TI-058, Rockwell Hanford Operations, Richland, WA. 
Jungfleisch, F.M., 1984b, TRAC: Preliminary Estimation of the Waste Inventories in Hanford Tanks Through 1980, SD-WM-TI-057, Rockwell Hanford Operations, Richland, WA.

Kocher, K. L., 1993. WHC 222-S and PNL Laboratories Single Shell Tank Waste Characterization, Tank T-105 Cores 53 and 54 Data Packages (Narrative) and Validation Summaries, WHC-SD-WM-DP-047, Rev. 0, Westinghouse Hanford Company, Richland, WA.

PNL, 1993. WHC 222-S and PNL Laboratories Single Shell Tank Waste Characterization, Tank T-105 Cores 53 and 54 Data Packages (Narrative) and Validation Summaries, WHC-SD-WM-DP-047, Rev. O, Addendum 2A, Westinghouse Hanford Company, Richland, WA.

Resource Conservation and Recovery Act, 42 U.S.C. 6901-6902 (1976).

Swaney, S.L., 1994. Single-Shell Tank Stabilization Record, WHC-SD-RE-178, Rev. 4, Westinghouse Hanford Company, Richland, WA.

Welty, R.K., 1988. Waste Storage Tank Status and Leak Detection Criteria, WHC-SD-WM-TI356, Vol. 2, Westinghouse Hanford Company, Richland, WA.

Wheeler, R.E., 1974. Analysis of Tank Farm Samples - Sample: T-4927, Tank 105-T, (Letter to R.L. Walser, September 17), Atlantic Richfield Hanford Company, Richland, WA. 
WHC-SD-WM-ER-369 REV O

\section{APPENDIX A}

ANALYTICAL RESULTS 


\section{A.1 INTRODUCTION}

A.1.1 Appendix A presents the chemical and radiological characteristics of Tank 241-T-105 in a tabular form, in terms of the specific concentrations of metals, anions, radionuclides, physical properties, organic complexes and volatile and semivolațile compounds.

The data table for each analyte lists laboratory sample identification, an analytical data result for each sample, range of results, standard deviation, an evaluated data result, and a projected tank inventory for the particular analyte. The projected tank inventory column is not applicable for the specific gravity, $\mathrm{pH}$, or percent water data. The data are listed in standard notation for values $>0.001$ and $<100,000$. Values outside these limits are listed in scientific notation.

\section{A.2 TABLE DESCRIPTION.}

\section{A.2.1 Abbreviations}

Standard abbreviations are used to describe analytical methods.

\begin{tabular}{|l|l|}
\hline Metals: & $\begin{array}{l}\text { ICP - Inductively Coupled Plasma (generic for all metals unless } \\
\text { otherwise known) }\end{array}$ \\
\cline { 2 - 3 } & $\begin{array}{l}\text { GHAA - Gaseous Hydride Atomic Absorption } \\
\text { CVAA - Cold Vapor Atomic Absorption }\end{array}$ \\
\cline { 2 - 3 } & FAA - Flame Atomic Absorption \\
\hline Anions: & IC - Ion Chromatography \\
\cline { 2 - 3 } & ITS - Potentiometric Titration \\
\hline Radionuclides: & GEA - Gamma Energy Analysis \\
\cline { 2 - 3 } & AEA - Alpha Energy Analysis \\
\cline { 2 - 3 } & APC - Alpha Proportional Counting \\
\cline { 2 - 3 } & BPC - Beta Proportional Counting \\
\cline { 2 - 3 } & LSC - Liquid Scintillation Counting \\
\hline Physical Properties: & PT - Physical Testing \\
\cline { 2 - 3 } & DM - Direct Measurement \\
\cline { 2 - 2 } & TGA - Thermogravimetric Analysis \\
\hline
\end{tabular}




\section{WHC-SD-WM-ER-369 REV O}

\section{A.3 Column Headings}

A.3.1 The "Analyte" column contains, in addition to the name of the analyte or physical characteristic, information about the method of measurement, and in the case of the metals, information about the method of digestion. The method of digestion is listed for the metals, because unlike the other analytes, different digestion procedures are typically used for the same metal.

Possible digestion methods are: $d$ - direct; a - acid digestion; $w$ - water leach; and $f$ potassium hydroxide fusion, followed by acid digestion.

The analyte and method are presented as follows: "method.analyte," or, lin the case of a metal) "method.digestion.analyte." For example, the specific concentration of ${ }^{90} \mathrm{Sr}$ was measured with a beta proportional counter and is listed "BPC. ${ }^{90} \mathrm{Sr} . "$ A specific concentration of $\mathrm{Pb}$ was determined by the inductively coupled plasma method which was preceded by acid digestion, and is listed as "ICP.a.Pb."

A.3.2 The "Laboratory Sample Identification" column lists the samples for which the analyte was meas ared; this identification number is different from the number assigned to the samples at the tarik farm. Sampling rationale, locations, and descriptions of sampling events are containecl in Section 3.0.

A.3.3 "Analytical Data Result" is the specific concentration of the analyte determined at differerit sampling points. No quality control data such as matrix spikes, serial dilutions, or dupliciste analyses are listed. This information may be obtained from the Tank 241-T-105 data packages (Kocher, 1993 and Giamberardini, 1993). Data which was qualified as esrima ted (denoted by " $J$ " or "UJ" in the data package) will be enclosed in parentheses, i.e., (395) $\mathrm{j}: \mathrm{g} / \mathrm{ml}$. Unusable data (denoted by "R" in the data package) will be entered with a strikeout, i.e., $395 \mu \mathrm{g} / \mathrm{ml}$. Unqualified data will be entered in standard form.

A.3.4 The "Range of Values" column lists the highest and the lowest values for a particular anaiyte.

A.3.5 The Evaluated Data Result is derived as discussed in Section 5.0

A.3.6 Column 6 "Standard Deviation" is computed for those results greater than the detection limit.

A.3.7 Column 7, "Projected Inventory," is the product of the concentration of the analyte and the volume of the waste in the tank. 123,000 gallons or $8.71 \mathrm{E}+04 \mathrm{~L}$ liquid / 98,000 gallons or $3.71 \mathrm{E}+05 \mathrm{~L}$ solid). 
Preferred Digestion Method for Tank 241-T-105 Constituents

\begin{tabular}{|c|c|c|c|c|c|}
\hline Analyte & Digestion & Analyte & Digestion & Analyte & Digestion \\
\hline $\mathrm{Al}$ & ICP.f & $\mathrm{K}$ & ICP.a & ${ }^{241} \mathrm{Am}$ & GEA.RS \\
\hline $\mathrm{Sb}$ & ICP.W & $\mathrm{Sm}$ & ICP.f & ${ }^{125} \mathrm{Sb}$ & GEA.RS \\
\hline As & ICP.f & $\mathrm{Se}$ & ICP.W & ${ }^{14} \mathrm{C}$ & LSC \\
\hline $\mathrm{Be}$ & ICP.W & $\mathrm{Si}$ & ICP.f & ${ }^{144} \mathrm{CePr}$ & GEA.f \\
\hline $\mathrm{Bi}$ & ICP.a & $\mathrm{Ag}$ & ICP.f & ${ }^{60} \mathrm{Co}$ & GEA.RS \\
\hline $\mathrm{B}$ & ICP.W & $\mathrm{Na}$ & ICP.a & ${ }^{134} \mathrm{Cs}$ & GEA.RS \\
\hline $\mathrm{Cd}$ & ICP.f & $\mathrm{Sr}$ & ICP.a & ${ }^{137} \mathrm{Cs}$ & GEA.RS \\
\hline $\mathrm{Ca}$ & ICP.f & $S$ & ICP.W & 154:Eu & GEA.f \\
\hline $\mathrm{Ce}$ & ICP.f & $\mathrm{Ti}$ & ICP.f & ${ }^{155} \mathrm{Eu}$ & GEA.RS \\
\hline Cs & FAA.f & $\mathrm{TI}$ & ICP.a & ${ }^{40} \mathrm{~K}$ & GEA.w \\
\hline $\mathrm{Cr}$ & ICP.a & $\mathrm{U}$ & RAD.f & ${ }^{238} \mathrm{Pu}$ & AEA \\
\hline $\mathrm{Fe}$ & ICP.f & $\mathrm{Zr}$ & ICP.f & ${ }^{239 / 240} \mathrm{Pu}$ & Alpha \\
\hline La & ICP.a & $\mathrm{NH}_{3}$ & Dist/Titrat. & ${ }^{103} \mathrm{Ru}$ & GEA.f \\
\hline $\mathrm{Pb}$ & ICP.a & $\mathrm{Cl}^{-}$ & IC & ${ }^{106} \mathrm{RuRh}$ & GEA.f \\
\hline $\mathrm{Li}$ & ICP.a & $\mathrm{Cr}^{6+}$ & Spec.w & ${ }^{90} \mathrm{Sr}$ & $\mathrm{BPC}$ \\
\hline $\mathrm{Mg}$ & ICP.f & $\mathrm{CN}^{-}$ & Dist/Spec & ${ }^{99} \mathrm{TC}$ & LSC \\
\hline $\mathrm{Mn}$ & ICP.a & $F^{-}$ & IC & ${ }^{228} \mathrm{Th}$ & GEA.f \\
\hline $\mathrm{Hg}$ & CVAA & $\mathrm{OH}^{-}$ & ITS & ${ }^{3} \mathrm{H}$ & LSC \\
\hline Mo & ICP.W & $\mathrm{NO}_{3}^{-}$ & IC & Total $a$ & APC \\
\hline $\mathrm{Nd}$ & ICP.a & $\mathrm{NO}_{2}^{-}$ & IC & Total $a \mathrm{Pu}$ & AEA \\
\hline $\mathrm{Ni}$ & ICP.a & $\mathrm{PO}_{4}{ }^{3-}$ & IC & Total $\beta$ & BPC \\
\hline $\mathrm{P}$ & ICP.f & $\mathrm{SO}_{4}{ }^{2-}$ & IC & & \\
\hline
\end{tabular}




\section{LIST OF TABLES FOR APPENDIX A}

Table A-1. Tank 241-T-105 Analytical Data:

Aluminum ........................... A 6

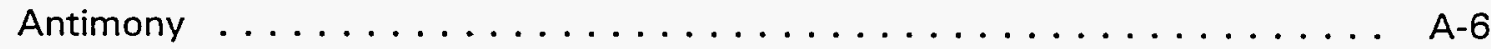

Arsenic ........................... A

Beryllium .......................... A $\ldots \ldots$

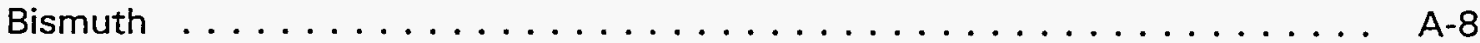

Boron ......................... A

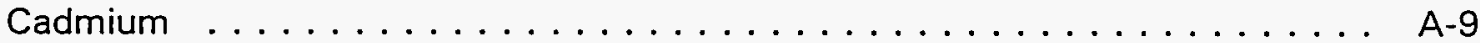

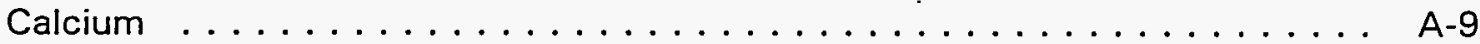

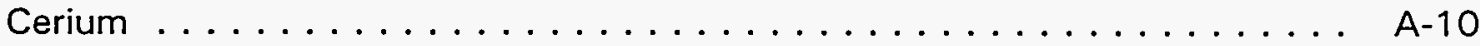

Cesium .......................... A

Chromium ...................... A-11

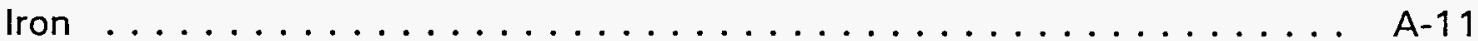

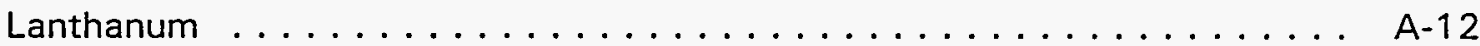

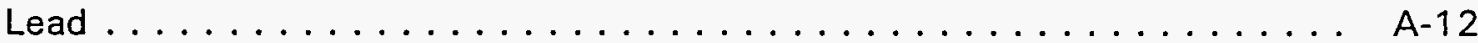

Lithium ........................... A $\ldots \ldots$

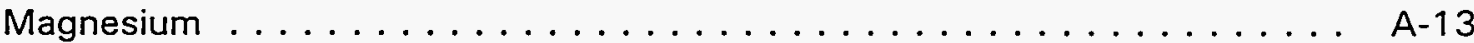

Manganese ......................... A-14

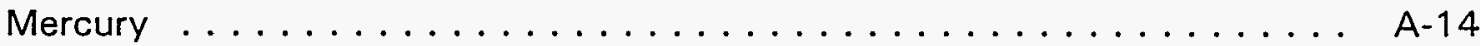

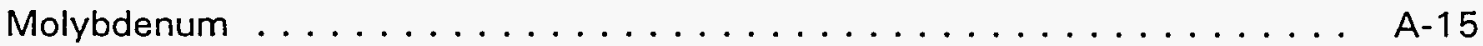

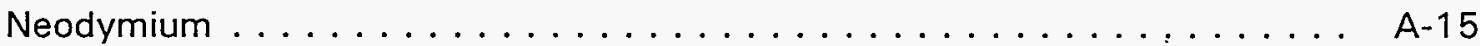

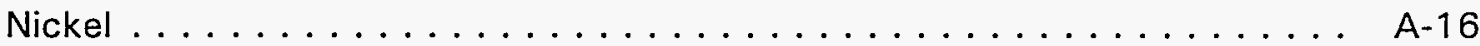

Phosphorus ....................... A-16

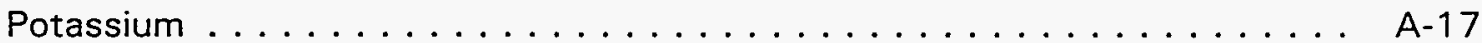

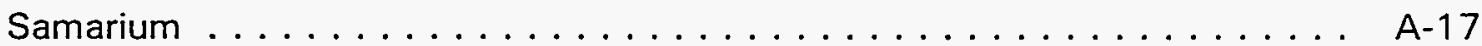

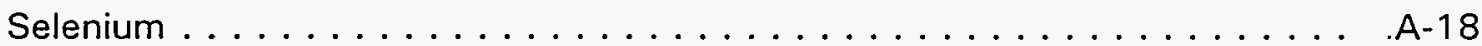

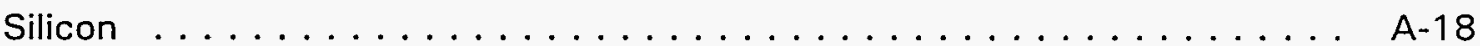

Silver ............................ A-19

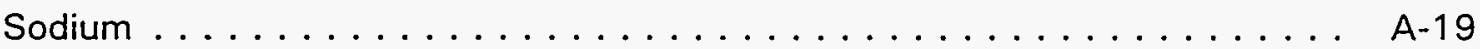

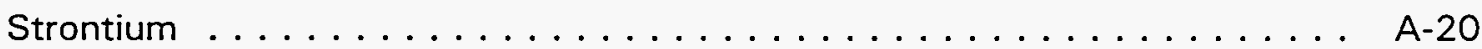

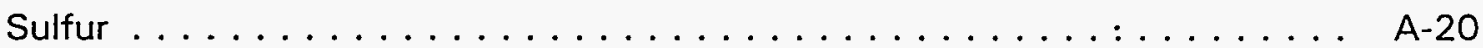

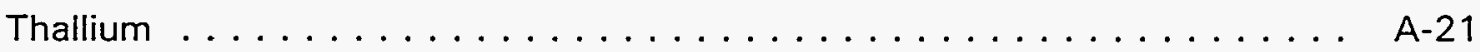

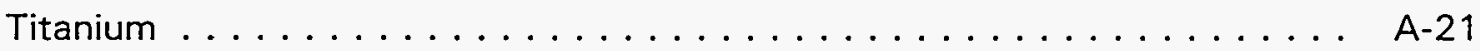

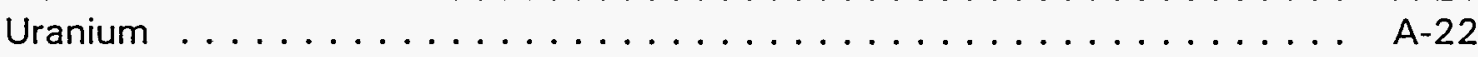

Zirconium ......................... A-22

Table A-2. Tank 241-T-105 Analytical Data:

Ammonia .......................... A-23

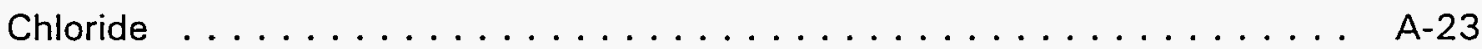

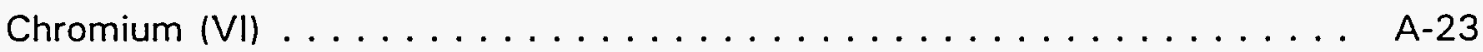

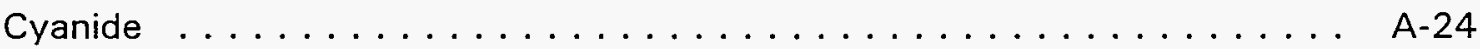

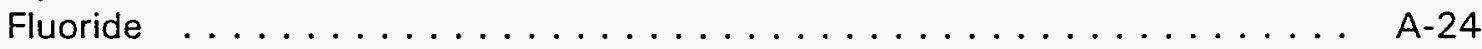

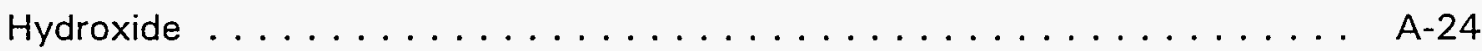

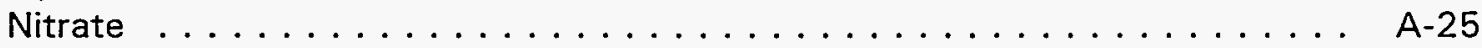

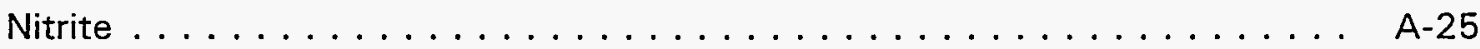

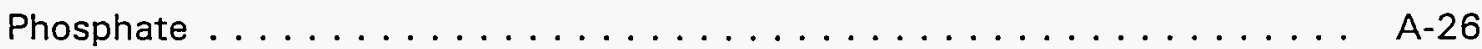

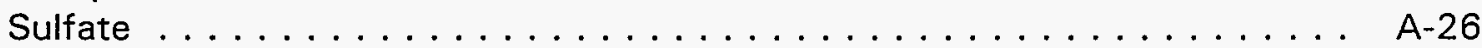

LATA-TCR-9411, Rev $0 \quad$ A-4 
LIST OF TABLES FOR APPENDIX A (continued)

,

Table A-3. Tank 241-T-105 Analytical Data:

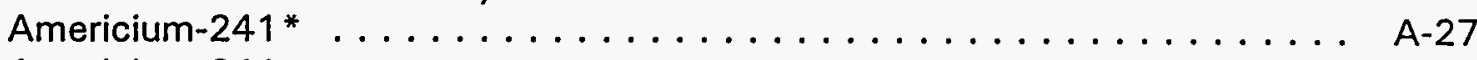

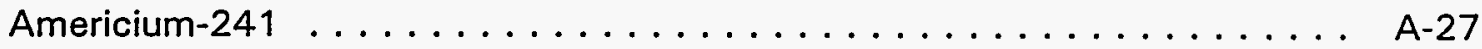

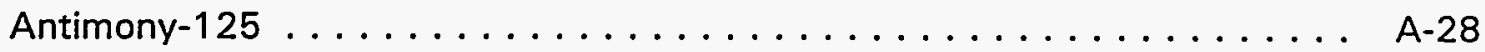

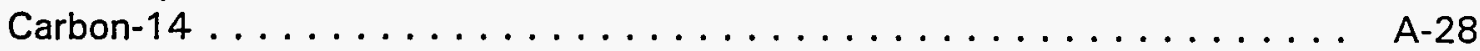

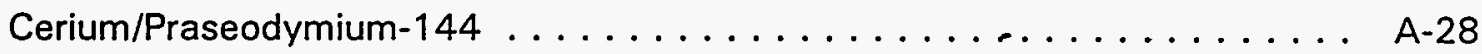

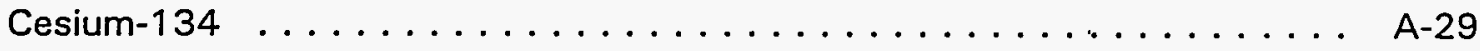

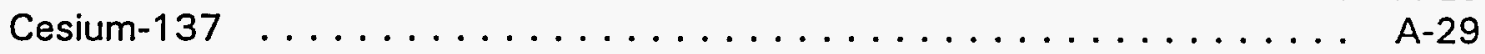

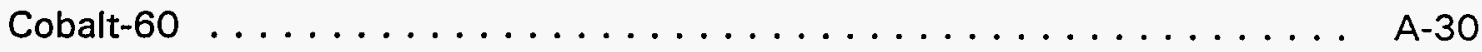

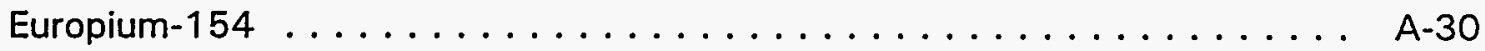

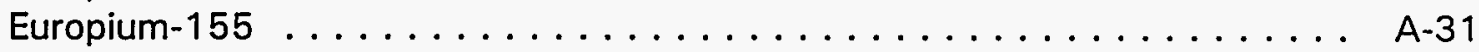

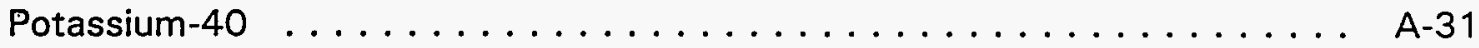

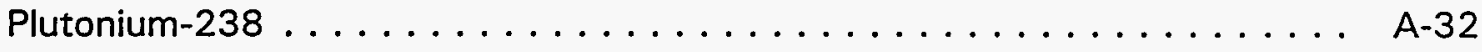

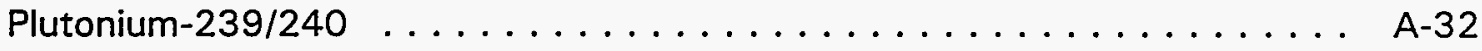

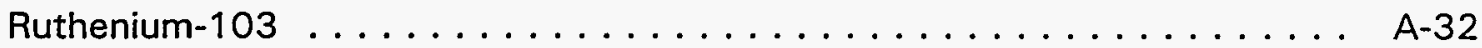

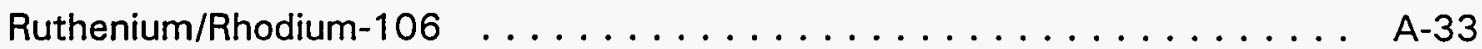

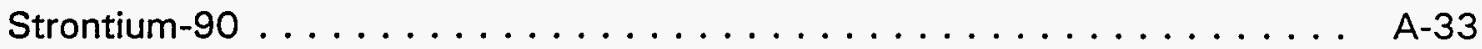

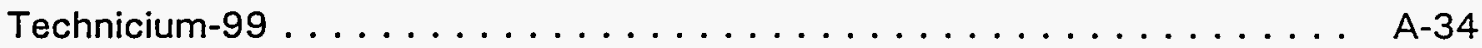

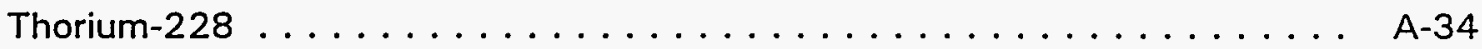

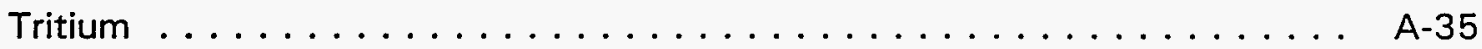

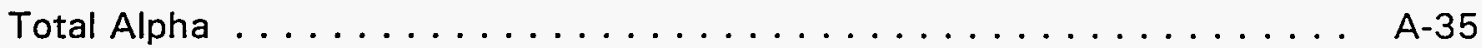

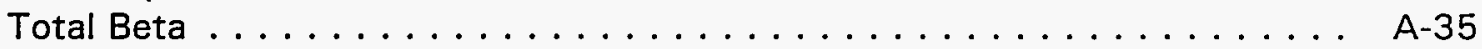

Percentage Plutonium . .................. A-36

Percentage Uranium $\ldots \ldots \ldots \ldots \ldots \ldots \ldots \ldots \ldots \ldots \ldots \ldots \ldots$

Table A-4. Tank 241-T-105 Analytical Data:

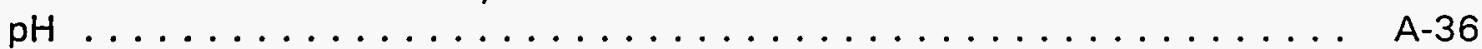

Specific Gravity . . . . . . . . . . . . . . . . . A-37

Thermo-Gravimetric Analysis . . . . . . . . . . . . . . . . A-37

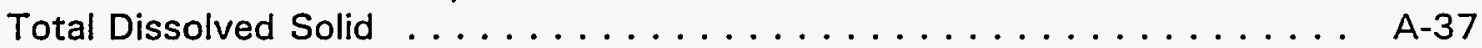

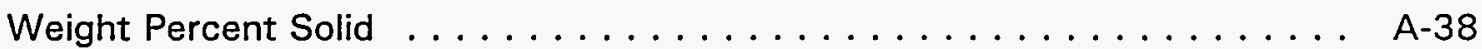

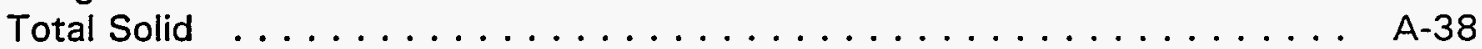

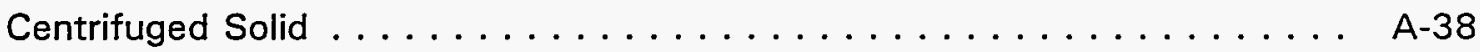

Residual Solid . . . . . . . . . . . . . . . . . . . A-39

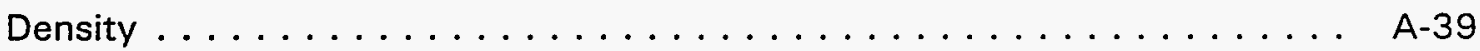

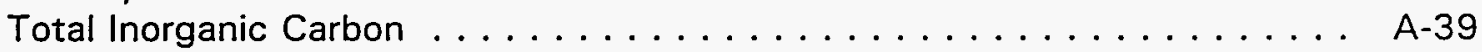

Total Organic Carbon . . . . . . . . . . . . . . . . . . . . A-40 
Table A-1. Tank 241-T-105 Analytical Data: Aluminum

\begin{tabular}{|c|c|c|c|c|c|c|}
\hline Analyte & $\begin{array}{l}\text { Laboratory } \\
\text { Sample } \\
\text { Identification }\end{array}$ & $\begin{array}{c}\text { Analytical } \\
\text { Data } \\
\text { Result }\end{array}$ & $\begin{array}{c}\text { Range } \\
\text { of } \\
\text { Values }\end{array}$ & Mean & $\begin{array}{c}\text { Standard } \\
\text { Deviation } \\
\text { (Mean) }\end{array}$ & $\begin{array}{l}\text { Projected } \\
\text { Inventory }\end{array}$ \\
\hline Metal & & $\mu \mathrm{g} / \mathrm{g}$ & $\mu \mathrm{g} / \mathrm{g}$ & $\mu \mathrm{g} / \mathrm{g}$ & $\mu \mathrm{g} / \mathrm{g}$ & $\mathrm{kg}$ \\
\hline \multirow[t]{2}{*}{ ICP.a.Al } & Sample D25-8755 & $(31,300)$ & \multirow{2}{*}{$\begin{array}{c}31,300 \\
\text { to } \\
1.54 E+05\end{array}$} & \multirow[t]{2}{*}{92,400} & \multirow[t]{2}{*}{61,100} & \multirow[t]{8}{*}{57,800} \\
\hline & Sample D33-8755 & $(1.54 E+05)$ & & & & \\
\hline \multirow{2}{*}{$\begin{array}{r}\text { Homogen. } \\
\text { Data }\end{array}$} & Sample D40-8755 & $(1.88 E+05)$ & \multirow{2}{*}{$\begin{array}{c}1.79 E+05 \\
\text { to } \\
1.88 E+05\end{array}$} & \multirow[t]{2}{*}{---} & \multirow[t]{2}{*}{---} & \\
\hline & Sample D41-8755 & $(1.79 E+05)$ & & & & \\
\hline \multirow[t]{2}{*}{ ICP.W.AI } & Sample D25-7755 & $(153)$ & \multirow{2}{*}{$\begin{array}{c}153 \\
\text { to } \\
412\end{array}$} & \multirow[t]{2}{*}{283} & \multirow[t]{2}{*}{130} & \\
\hline & Sample D33-7755 & $(412)$ & & & & \\
\hline \multirow[t]{2}{*}{ ICP.f.AI } & Sample D25-6775 & $(39,200)$ & \multirow{2}{*}{$\begin{array}{c}39,200 \\
\text { to } \\
1.51 E+05\end{array}$} & \multirow[t]{2}{*}{95,100} & \multirow[t]{2}{*}{55,900} & \\
\hline & Sample D33-6755 & $(1.51 E+05)$ & & & & \\
\hline
\end{tabular}

Table A-1. Tank 241-T-105 Analytical Data: Antimony

\begin{tabular}{|c|c|c|c|c|c|c|}
\hline Analyte & $\begin{array}{l}\text { Laboratory } \\
\text { Sample } \\
\text { Identification }\end{array}$ & $\begin{array}{c}\text { Analytical } \\
\text { Data } \\
\text { Result }\end{array}$ & $\begin{array}{c}\text { Range } \\
\text { of } \\
\text { Values }\end{array}$ & Mean & $\begin{array}{c}\text { Standard } \\
\text { Deviation } \\
\text { (Mean) }\end{array}$ & $\begin{array}{l}\text { Projected } \\
\text { Inventory }\end{array}$ \\
\hline Metal & & $\mu \mathrm{g} / \mathrm{g}$ & $\mu \mathrm{g} / \mathrm{g}$ & $\mu \mathrm{g} / \mathrm{g}$ & $\mu \mathrm{g} / \mathrm{g}$ & $\mathrm{kg}$ \\
\hline \multirow[t]{2}{*}{ ICP.a.Sb } & Sample D25-8755 & $(<126)$ & \multirow{2}{*}{$\begin{array}{c}<126 \\
\text { to } \\
<128\end{array}$} & \multirow[t]{2}{*}{$<128$} & \multirow[t]{2}{*}{ N/A } & \multirow[t]{8}{*}{14.4} \\
\hline & Sample D33-8755 & $(<128)$ & & & & \\
\hline \multirow{2}{*}{$\begin{array}{r}\text { Homogen. } \\
\text { Data }\end{array}$} & Sample D40-8755 & $(<129)$ & \multirow{2}{*}{$\begin{array}{c}<128 \\
\text { to } \\
<129\end{array}$} & \multirow[t]{2}{*}{$\cdots$} & \multirow[t]{2}{*}{--} & \\
\hline & Sample D41-8755 & $(<128)$ & & & & \\
\hline \multirow[t]{2}{*}{ ICP.w.Sb } & Sample D25-7755 & $(23.7)$ & \multirow{2}{*}{$\begin{array}{c}23.7 \\
\text { to } \\
<\quad 132\end{array}$} & \multirow[t]{2}{*}{23.7} & \multirow[t]{2}{*}{ N/A } & \\
\hline & Sample D33-7755 & $1<132)$ & & & & \\
\hline \multirow[t]{2}{*}{ ICP.f.Sb } & Sample D25-6775 & $(<104)$ & \multirow{2}{*}{$\begin{array}{l}<104 \\
\text { to } \\
<105\end{array}$} & \multirow[t]{2}{*}{$<105$} & \multirow[t]{2}{*}{ N/A } & \\
\hline & Sample D33-6755 & $(<105)$ & & & & \\
\hline
\end{tabular}


Table A-1. Tank 241-T-105 Analytical Data: Arsenic

\begin{tabular}{|c|c|c|c|c|c|c|}
\hline Analyte & $\begin{array}{c}\text { Laboratory } \\
\text { Sample } \\
\text { Identification }\end{array}$ & $\begin{array}{c}\text { Analytical } \\
\text { Data } \\
\text { Result }\end{array}$ & $\begin{array}{c}\text { Range } \\
\text { of } \\
\text { Values }\end{array}$ & Mean & $\begin{array}{c}\text { Standard } \\
\text { Deviation } \\
\text { (Mean) }\end{array}$ & $\begin{array}{l}\text { Projected } \\
\text { Inventory }\end{array}$ \\
\hline Metal & & $\mu \mathrm{g} / \mathrm{g}$ & $\mu \mathrm{g} / \mathrm{g}$ & $\mu \mathrm{g} / \mathrm{g}$ & $\mu \mathrm{g} / \mathrm{g}$ & $\mathrm{kg}$ \\
\hline \multirow[t]{2}{*}{ ICP.a.As } & Sample D25-8755 & $<26.5$ & \multirow{2}{*}{$\begin{array}{c}<26.5 \\
\text { to } \\
<26.9\end{array}$} & \multirow[t]{2}{*}{$<26.9$} & \multirow[t]{2}{*}{ N/A } & \multirow[t]{8}{*}{15.8} \\
\hline & Sample D33-8755 & $<26.9$ & & & & \\
\hline \multirow{2}{*}{$\begin{array}{r}\text { Homogen. } \\
\text { Data }\end{array}$} & Sample D40-8755 & $1<26.9)$ & \multirow{2}{*}{$\begin{array}{c}<26.8 \\
\text { to } \\
<26.9\end{array}$} & \multirow[t]{2}{*}{---} & \multirow[t]{2}{*}{---} & \\
\hline & Sample D41-8755 & $1<26.81$ & & & & \\
\hline \multirow[t]{2}{*}{ ICP.w.As } & Sample D25-7755 & $<3.08$ & \multirow{2}{*}{$\begin{array}{l}<3.08 \\
\text { to } \\
<27.7\end{array}$} & \multirow{2}{*}{$<27.7$} & \multirow[t]{2}{*}{ N/A } & \\
\hline & Sample D33-7755 & $(<27.7)$ & & & & \\
\hline \multirow[t]{2}{*}{ ICP.f.As } & Sample D25-6775 & $<14.8$ & \multirow[t]{2}{*}{ N/A } & \multirow[t]{2}{*}{26.0} & \multirow[t]{2}{*}{$N / A$} & \\
\hline & Sample D33-6755 & 26.0 & & & & \\
\hline
\end{tabular}

Table A-1. Tank 241-T-105 Analytical Data: Beryilium

\begin{tabular}{|c|c|c|c|c|c|c|}
\hline Analyte & $\begin{array}{l}\text { Laboratory } \\
\text { Sample } \\
\text { Identification }\end{array}$ & $\begin{array}{c}\text { Analytical } \\
\text { Data } \\
\text { Result }\end{array}$ & $\begin{array}{c}\text { Range } \\
\text { of } \\
\text { Values }\end{array}$ & Mean & $\begin{array}{c}\text { Standard } \\
\text { Deviation } \\
\text { (Mean) }\end{array}$ & $\begin{array}{l}\text { Projected } \\
\text { Inventory }\end{array}$ \\
\hline Metal & & $\mu \mathrm{g} / \mathrm{g}$ & $\mu \mathrm{g} / \mathrm{g}$ & $\mu \mathrm{g} / \mathrm{g}$ & $\mu \mathrm{g} / \mathrm{g}$ & $\mathrm{kg}$ \\
\hline \multirow[t]{2}{*}{ ICP.a.Be } & Sample D25-8755 & $<2.94$ & \multirow{2}{*}{$\begin{array}{l}<2.94 \\
\text { to } \\
<2.99\end{array}$} & \multirow[t]{2}{*}{$<2.99$} & \multirow[t]{2}{*}{ N/A } & \multirow[t]{8}{*}{1.87} \\
\hline & Sample D33-8755 & $<2.99$ & & & & \\
\hline \multirow{2}{*}{$\begin{array}{r}\text { Homogen. } \\
\text { Data }\end{array}$} & Sample D40-8755 & $(<2.99)$ & \multirow{2}{*}{$\begin{array}{l}<2.98 \\
\text { to } \\
<2.99\end{array}$} & \multirow[t]{2}{*}{$\cdots$} & \multirow[t]{2}{*}{--} & \\
\hline & Sample D41-8755 & $(<2.98)$ & & & & \\
\hline \multirow[t]{2}{*}{ ICP.W.Be } & Sample D25-7755 & $(<0.308)$ & \multirow{2}{*}{$\begin{array}{c}<0.308 \\
\text { to } \\
3.08\end{array}$} & \multirow[t]{2}{*}{3.08} & \multirow[t]{2}{*}{ N/A } & \\
\hline & Sample D33-7755 & $(3.08)$ & & & & \\
\hline \multirow[t]{2}{*}{ ICP.f.Be } & Sample D25-6775 & $<1.48$ & \multirow{2}{*}{$\begin{array}{c}<1.48 \\
\text { to } \\
<1.49\end{array}$} & \multirow[t]{2}{*}{$<1.49$} & \multirow[t]{2}{*}{ N/A } & \\
\hline & Sample D33-6755 & $<1.49$ & & & & \\
\hline
\end{tabular}


WHC-SD-WM-ER-369 REV O

Table A-1. Tank 241-T-105 Analytical Data: Bismuth

\begin{tabular}{|c|c|c|c|c|c|c|}
\hline Analyte & $\begin{array}{l}\text { Laboratory } \\
\text { Sample } \\
\text { Identification }\end{array}$ & $\begin{array}{c}\text { Analytical } \\
\text { Data } \\
\text { Result }\end{array}$ & $\begin{array}{c}\text { Range } \\
\text { of } \\
\text { Values }\end{array}$ & Mean & $\begin{array}{c}\text { Standard } \\
\text { Deviation } \\
\text { (Mean) }\end{array}$ & $\begin{array}{l}\text { Projected } \\
\text { Inventory }\end{array}$ \\
\hline Metal & & $\mu \mathrm{g} / \mathrm{g}$ & $\mu \mathrm{g} / \mathrm{g}$ & $\mu \mathrm{g} / \mathrm{g}$ & $\mu \mathrm{g} / \mathrm{g}$ & $\mathrm{kg}$ \\
\hline \multirow[t]{2}{*}{ ICP.a.Bi } & Sample D25-8755 & 1,260 & \multirow{2}{*}{$\begin{array}{c}1,260 \\
\text { to } \\
1,400\end{array}$} & \multirow[t]{2}{*}{1,330} & \multirow[t]{2}{*}{75.5} & \multirow[t]{8}{*}{809} \\
\hline & Sample D33-8755 & 1,400 & & & & \\
\hline \multirow{2}{*}{$\begin{array}{r}\text { Homogen. } \\
\text { Data }\end{array}$} & Sample D40-8755 & $(1,290)$ & \multirow{2}{*}{$\begin{array}{c}1,290 \\
\text { to } \\
1,390\end{array}$} & \multirow[t]{2}{*}{$\cdots$} & \multirow[t]{2}{*}{-.- } & \\
\hline & Sample D41-8755 & $(1,390)$ & & & & \\
\hline \multirow[t]{2}{*}{ ICP.w.Bi } & Sample D25-7755 & $(<6.47)$ & \multirow{2}{*}{$\begin{array}{c}<6.47 \\
\text { to } \\
44.1\end{array}$} & \multirow[t]{2}{*}{44.1} & \multirow[t]{2}{*}{ N/A } & \\
\hline & Sample D33-7755 & $(44.1)$ & & & & \\
\hline \multirow[t]{2}{*}{ ICP.f.Bi } & Sample D25-6775 & $(1,050)$ & \multirow{2}{*}{$\begin{array}{c}1,050 \\
\text { to } \\
1,380\end{array}$} & \multirow[t]{2}{*}{1,220} & \multirow[t]{2}{*}{163} & \\
\hline & Sample D33-6755 & $(1,380)$ & & & & \\
\hline
\end{tabular}

Table A-1. Tank 241-T-105 Analytical Data: Boron

\begin{tabular}{|c|c|c|c|c|c|c|}
\hline Analyte & $\begin{array}{l}\text { Laboratory } \\
\text { Sample } \\
\text { Identification }\end{array}$ & $\begin{array}{c}\text { Analytical } \\
\text { Data } \\
\text { Result }\end{array}$ & $\begin{array}{c}\text { Range } \\
\text { of } \\
\text { Values }\end{array}$ & Mean & $\begin{array}{c}\text { Standard } \\
\text { Deviation } \\
\text { (Mean) }\end{array}$ & $\begin{array}{l}\text { Projected } \\
\text { Inventory }\end{array}$ \\
\hline Metal & & $\mu \mathrm{g} / \mathrm{g}$ & $\mu \mathrm{g} / \mathrm{g}$ & $\mu \mathrm{g} / \mathrm{g}$ & $\mu \mathrm{g} / \mathrm{g}$ & $\mathrm{kg}$ \\
\hline \multirow[t]{2}{*}{ ICP.a.B } & Sample D25-8755 & $(<22.5)$ & \multirow{2}{*}{$\begin{array}{c}<22.5 \\
\text { to } \\
<22.9\end{array}$} & \multirow[t]{2}{*}{$<22.9$} & \multirow[t]{2}{*}{$N / A$} & \multirow[t]{8}{*}{204} \\
\hline & Sample D33-8755 & $1<22.9\}$ & & & & \\
\hline \multirow{2}{*}{$\begin{array}{r}\text { Homogen. } \\
\text { Data }\end{array}$} & Sample D40-8755 & $1<23.01$ & \multirow{2}{*}{$\begin{aligned}< & 22.8 \\
& \text { to } \\
< & 23.0\end{aligned}$} & \multirow[t]{2}{*}{$\cdots$} & \multirow[t]{2}{*}{$\cdots$} & \\
\hline & Sample D41-8755 & $1<22.81$ & & & & \\
\hline \multirow[t]{2}{*}{ ICP.W.B } & Sample D25-7755 & $(303)$ & \multirow{2}{*}{$\begin{array}{c}303 \\
\text { to } \\
368\end{array}$} & \multirow[t]{2}{*}{335} & \multirow[t]{2}{*}{32.6} & \\
\hline & Sample D33-7755 & $(368)$ & & & & \\
\hline \multirow[t]{2}{*}{ ICP.f.B } & Sample D25-6775 & $<4.9 .4$ & \multirow{2}{*}{$\begin{array}{l}<4.94 \\
\text { to } \\
<4.98\end{array}$} & \multirow[t]{2}{*}{$<4.98$} & \multirow[t]{2}{*}{$N / A$} & \\
\hline & Sample D33-6755 & $<4.98$ & & & & \\
\hline
\end{tabular}


Table A-1. Tank 241-T-105 Analytical Data: Cadmium

\begin{tabular}{|c|c|c|c|c|c|c|}
\hline Analyte & $\begin{array}{c}\text { Laboratory } \\
\text { Sample } \\
\text { Identification }\end{array}$ & $\begin{array}{c}\text { Analytical } \\
\text { Data } \\
\text { Result }\end{array}$ & $\begin{array}{c}\text { Range } \\
\text { of } \\
\text { Values }\end{array}$ & Mean & $\begin{array}{c}\text { Standard } \\
\text { Deviation } \\
\text { (Mean) }\end{array}$ & $\begin{array}{l}\text { Projected } \\
\text { Inventory }\end{array}$ \\
\hline Metal & & $\mu \mathrm{g} / \mathrm{g}$ & $\mu \mathrm{g} / \mathrm{g}$ & $\mu \mathrm{g} / \mathrm{g}$ & $\mu \mathrm{g} / \mathrm{g}$ & $\mathrm{kg}$ \\
\hline \multirow[t]{2}{*}{ ICP.a.Cd } & Sample D25-8755 & $(19.6)$ & \multirow{2}{*}{$\begin{array}{l}5.26 \\
\text { to } \\
19.6\end{array}$} & \multirow[t]{2}{*}{12.1} & \multirow[t]{2}{*}{7.46} & \multirow[t]{8}{*}{9.36} \\
\hline & Sample D33-8755 & 5.26 & & & & \\
\hline \multirow{2}{*}{$\begin{array}{r}\text { Homogen. } \\
\text { Data }\end{array}$} & Sample D40-8755 & $(5.01)$ & \multirow{2}{*}{$\begin{array}{l}5.01 \\
\text { to } \\
15.9\end{array}$} & \multirow[t]{2}{*}{---} & \multirow[t]{2}{*}{--} & \\
\hline & Sample D41-8755 & $(15.9)$ & & & & \\
\hline \multirow[t]{2}{*}{ ICP.w.Cd } & Sample D25-7755 & $(2.81)$ & \multirow{2}{*}{$\begin{array}{c}2.81 \\
\text { to } \\
<4.11\end{array}$} & \multirow[t]{2}{*}{2.81} & \multirow[t]{2}{*}{ N/A } & \\
\hline & Sample D33-7755 & $(<4.11)$ & & & & \\
\hline \multirow[t]{2}{*}{ ICP.f.Cd } & Sample D25-6775 & 19.2 & \multirow{2}{*}{$\begin{array}{l}11.5 \\
\text { to } \\
19.2\end{array}$} & \multirow[t]{2}{*}{15.4} & \multirow[t]{2}{*}{3.82} & \\
\hline & Sample D33-6755 & 11.5 & & & & \\
\hline
\end{tabular}

Table A-1. Tank 241-T-105 Analytical Data: Calcium

\begin{tabular}{|c|c|c|c|c|c|c|}
\hline Analyte & $\begin{array}{l}\text { Laboratory } \\
\text { Sample } \\
\text { Identification }\end{array}$ & $\begin{array}{c}\text { Analytical } \\
\text { Data } \\
\text { Result }\end{array}$ & $\begin{array}{c}\text { Range } \\
\text { of } \\
\text { Values }\end{array}$ & Mean & $\begin{array}{c}\text { Standard } \\
\text { Deviation } \\
\text { (Mean) }\end{array}$ & $\begin{array}{l}\text { Projected } \\
\text { Inventory }\end{array}$ \\
\hline Metal & & $\mu \mathrm{g} / \mathrm{g}$ & $\mu \mathrm{g} / \mathrm{g}$ & $\mu \mathrm{g} / \mathrm{g}$ & $\mu \mathrm{g} / \mathrm{g}$ & $\mathrm{kg}$ \\
\hline \multirow[t]{2}{*}{ ICP.a.Ca } & Sample D25-8755 & $(1,500)$ & \multirow{2}{*}{$\begin{array}{c}1,330 \\
\text { to } \\
1,500\end{array}$} & \multirow[t]{2}{*}{1,420} & \multirow[t]{2}{*}{82.5} & \multirow[t]{8}{*}{2,230} \\
\hline & Sample D33-8755 & $(1,330)$ & & & & \\
\hline \multirow{2}{*}{$\begin{array}{r}\text { Homogen. } \\
\text { Data }\end{array}$} & Sample D40-8755 & $(1,140)$ & \multirow{2}{*}{$\begin{array}{c}1,140 \\
\text { to } \\
1,330\end{array}$} & \multirow[t]{2}{*}{--} & \multirow[t]{2}{*}{--} & \\
\hline & Sample D41-8755 & $(1,330)$ & & & & \\
\hline \multirow[t]{2}{*}{ ICP.w.Ca } & Sample D25-7755 & $(117)$ & \multirow{2}{*}{$\begin{array}{l}117 \\
\text { to } \\
457\end{array}$} & \multirow[t]{2}{*}{287} & \multirow[t]{2}{*}{170} & \\
\hline & Sample D33-7755 & $(457)$ & & & & \\
\hline \multirow[t]{2}{*}{ ICP.f.Ca } & Sample D25-6775 & $(5,050)$ & \multirow{2}{*}{$\begin{array}{c}2,290 \\
\text { to } \\
5,050\end{array}$} & \multirow[t]{2}{*}{3,670} & \multirow[t]{2}{*}{1,380} & \\
\hline & Sample D33-6755 & $(2,290)$ & & & & \\
\hline
\end{tabular}


Table A-1. Tank 241-T-105 Analytical Data: Cerium

\begin{tabular}{|c|c|c|c|c|c|c|}
\hline Analyte & $\begin{array}{l}\text { Laboratory } \\
\text { Sample } \\
\text { identification }\end{array}$ & $\begin{array}{c}\text { Analytical } \\
\text { Data } \\
\text { Result }\end{array}$ & $\begin{array}{c}\text { Range } \\
\text { of } \\
\text { Values }\end{array}$ & Mean & $\begin{array}{c}\text { Standard } \\
\text { Deviation } \\
\text { (Mean) }\end{array}$ & $\begin{array}{l}\text { Projected } \\
\text { Inventory }\end{array}$ \\
\hline Metal & & $\mu \mathrm{g} / \mathrm{g}$ & $\mu \mathrm{g} / \mathrm{g}$ & $\mu \mathrm{g} / \mathrm{g}$ & $\mu \mathrm{g} / \mathrm{g}$ & $\mathrm{kg}$ \\
\hline \multirow[t]{2}{*}{ ICP.a.Ce } & Sample D25-8755 & $(<40.2)$ & \multirow{2}{*}{$\begin{array}{l}<40.2 \\
\text { to } \\
<40.8\end{array}$} & \multirow[t]{2}{*}{$<40.8$} & \multirow[t]{2}{*}{ N/A } & \multirow[t]{8}{*}{48.0} \\
\hline & Sample D33-8755 & $(<40.8)$ & & & & \\
\hline \multirow{2}{*}{$\begin{array}{r}\text { Homogen. } \\
\text { Data }\end{array}$} & Sample D40-8755 & $(<40.9)$ & \multirow{2}{*}{$\begin{array}{l}<40.7 \\
\text { to } \\
<40.9\end{array}$} & \multirow[t]{2}{*}{--} & \multirow[t]{2}{*}{--} & \\
\hline & Sample D41-8755 & $(<40.7)$ & & & & \\
\hline \multirow[t]{2}{*}{ ICP.W.Ce } & Sample D25-7755 & $\mid<6.99)$ & \multirow{2}{*}{$\begin{array}{l}<6.99 \\
\text { to } \\
<42.1\end{array}$} & \multirow[t]{2}{*}{$<42.1$} & \multirow[t]{2}{*}{ N/A } & \\
\hline & Sample D33-7755 & $1<42.1)$ & & & & \\
\hline \multirow[t]{2}{*}{ ICP.f.Ce } & Sample D25-6775 & $(112)$ & \multirow{2}{*}{$\begin{array}{c}46.0 \\
\text { to } \\
112\end{array}$} & \multirow[t]{2}{*}{79.0} & \multirow[t]{2}{*}{33.0} & \\
\hline & Sample D33-6755 & $(46.0)$ & & & & \\
\hline
\end{tabular}

Table A-1. Tank 241-T-105 Analytical Data: Cesium

\begin{tabular}{|c|c|c|c|c|c|c|}
\hline Analyte & $\begin{array}{l}\text { Laboratory } \\
\text { Sample } \\
\text { Identification }\end{array}$ & $\begin{array}{c}\text { Analytical } \\
\text { Data } \\
\text { Result }\end{array}$ & $\begin{array}{c}\text { Range } \\
\text { of } \\
\text { Values }\end{array}$ & $\begin{array}{c}\text { Largest } \\
\text { Detection } \\
\text { Limit }\end{array}$ & $\begin{array}{c}\text { Standard } \\
\text { Deviation } \\
\text { (Mean) }\end{array}$ & $\begin{array}{l}\text { Projected } \\
\text { Inventory }\end{array}$ \\
\hline Metal & & $\mu \mathrm{g} / \mathrm{g}$ & $\mu \mathrm{g} / \mathrm{g}$ & $\mu \mathrm{g} / \mathrm{g}$ & $\mu \mathrm{g} / \mathrm{g}$ & $\mathrm{kg}$ \\
\hline \multirow[t]{2}{*}{ FAA.a.Cs } & Sample D25-8794 & $<200$ & \multirow{2}{*}{$\begin{array}{c}<140 \\
\text { to } \\
<200\end{array}$} & \multirow[t]{2}{*}{$<200$} & \multirow[t]{2}{*}{ N/A } & \multirow[t]{4}{*}{$<608$} \\
\hline & Sample D33-8794 & $1<140)$ & & & & \\
\hline \multirow[t]{2}{*}{ FAA.f.Cs } & Sample D25-6793 & $<700$ & \multirow{2}{*}{$\begin{array}{c}<700 \\
\text { to } \\
<1000\end{array}$} & \multirow[t]{2}{*}{$<1000$} & \multirow[t]{2}{*}{$N / A$} & \\
\hline & Sample D33-6793 & $<1000$ & & & & \\
\hline
\end{tabular}


Table A-1. Tank 241-T-105 Analytical Data: Chromium

\begin{tabular}{|c|c|c|c|c|c|c|}
\hline Analyte & $\begin{array}{c}\text { Laboratory: } \\
\text { Sample } \\
\text { Identification }\end{array}$ & $\begin{array}{c}\text { Analytical } \\
\text { Data } \\
\text { Result }\end{array}$ & $\begin{array}{c}\text { Range } \\
\text { of } \\
\text { Values }\end{array}$ & Mean & $\begin{array}{c}\text { Standard } \\
\text { Deviation } \\
\text { (Mean) }\end{array}$ & $\begin{array}{l}\text { Projected } \\
\text { Inventory }\end{array}$ \\
\hline Metal & & $\mu \mathrm{g} / \mathrm{g}$ & $\mu \mathrm{g} / \mathrm{g}$ & $\mu \mathrm{g} / \mathrm{g}$ & $\mu \mathrm{g} / \mathrm{g}$ & $\mathrm{kg}$ \\
\hline \multirow[t]{2}{*}{ ICP.a.Cr } & Sample D25-8755 & 726 & \multirow{2}{*}{$\begin{array}{l}284 \\
\text { to } \\
726\end{array}$} & \multirow[t]{2}{*}{505} & \multirow[t]{2}{*}{221} & \multirow[t]{8}{*}{307} \\
\hline & Sample D33-8755 & 284 & & & & \\
\hline \multirow{2}{*}{$\begin{array}{r}\text { Homogen. } \\
\text { Data }\end{array}$} & Sample D40-8755 & $(258)$ & \multirow{2}{*}{$\begin{array}{l}258 \\
\text { to } \\
272\end{array}$} & \multirow[t]{2}{*}{--} & \multirow[t]{2}{*}{---} & \\
\hline & Sample D41-8755 & $(272)$ & & & & \\
\hline \multirow[t]{2}{*}{ ICP.w.Cr } & Sample D25-7755 & $(200)$ & \multirow{2}{*}{$\begin{array}{l}95.3 \\
\text { to } \\
200 \\
\end{array}$} & \multirow[t]{2}{*}{148} & \multirow[t]{2}{*}{52.6} & \\
\hline & Sample D33-7755 & $(95.3)$ & & & & \\
\hline \multirow[t]{2}{*}{ ICP.f.Cr } & Sample D25-6775 & $(613)$ & \multirow{2}{*}{$\begin{array}{l}252 \\
\text { to } \\
613\end{array}$} & \multirow[t]{2}{*}{432} & \multirow[t]{2}{*}{180} & \\
\hline & Sample D33-6755 & 252 & & & & \\
\hline
\end{tabular}

Table A-1. Tank 241-T-105 Analytical Data: Iron

\begin{tabular}{|c|c|c|c|c|c|c|}
\hline Analyte & $\begin{array}{l}\text { Laboratory } \\
\text { Sample } \\
\text { Identification }\end{array}$ & $\begin{array}{c}\text { Analytical } \\
\text { Data } \\
\text { Result }\end{array}$ & $\begin{array}{c}\text { Range } \\
\text { of } \\
\text { Values }\end{array}$ & Mean & $\begin{array}{c}\text { Standard } \\
\text { Deviation } \\
\text { (Mean) }\end{array}$ & $\begin{array}{l}\text { Projected } \\
\text { Inventory }\end{array}$ \\
\hline Metal & & $\mu \mathrm{g} / \mathrm{g}$ & $\mu \mathrm{g} / \mathrm{g}$ & $\mu \mathrm{g} / \mathrm{g}$ & $\mu \mathrm{g} / \mathrm{g}$ & $\mathrm{kg}$ \\
\hline \multirow[t]{2}{*}{ ICP.a.Fe } & Sample D25-8755 & $(45,500)$ & \multirow{2}{*}{$\begin{array}{c}9,090 \\
\text { to } \\
45,500\end{array}$} & \multirow[t]{2}{*}{27,300} & \multirow[t]{2}{*}{18,200} & \multirow[t]{8}{*}{20,100} \\
\hline & Sample D33-8755 & 9,090 & & & & \\
\hline \multirow{2}{*}{$\begin{array}{r}\text { Homogen. } \\
\text { Data }\end{array}$} & Sample D40-8755 & $(12,000)$ & \multirow{2}{*}{$\begin{array}{c}12,000 \\
\text { to } \\
17,200\end{array}$} & \multirow[t]{2}{*}{--} & \multirow[t]{2}{*}{--} & \\
\hline & Sample D41-8755 & $(17,200)$ & & & & \\
\hline \multirow[t]{2}{*}{ ICP.W.Fe } & Sample D25-7755 & $(2.64)$ & \multirow{2}{*}{$\begin{array}{c}2.64 \\
\text { to } \\
18.2\end{array}$} & \multirow[t]{2}{*}{10.4} & \multirow[t]{2}{*}{7.78} & \\
\hline & Sample D33-7755 & $(18.2)$ & & & & \\
\hline \multirow[t]{2}{*}{ ICP.f.Fe } & Sample D25-6775 & $(40,600)$ & \multirow{2}{*}{$\begin{array}{c}25,500 \\
\text { to } \\
40,600\end{array}$} & \multirow[t]{2}{*}{33,100} & \multirow[t]{2}{*}{7,550} & \\
\hline & Sample D33-6755 & 25,500 & & & & \\
\hline
\end{tabular}


Table A-1. Tank 241-T-105 Analytical Data: Lanthanum

\begin{tabular}{|c|c|c|c|c|c|c|}
\hline Analyte & $\begin{array}{l}\text { Laboratory } \\
\text { Sample } \\
\text { Identification }\end{array}$ & $\begin{array}{c}\text { Analytical } \\
\text { Data } \\
\text { Result }\end{array}$ & $\begin{array}{c}\text { Range } \\
\text { of } \\
\text { Values }\end{array}$ & Mean & $\begin{array}{c}\text { Standard } \\
\text { Deviation } \\
\text { (Mean) }\end{array}$ & $\begin{array}{l}\text { Projected } \\
\text { Inventory }\end{array}$ \\
\hline Metal & & $\mu \mathrm{g} / \mathrm{g}$ & $\mu \mathrm{g} / \mathrm{g}$ & $\mu \mathrm{g} / \mathrm{g}$ & $\mu \mathrm{g} / \mathrm{g}$ & $\mathrm{kg}$ \\
\hline \multirow[t]{2}{*}{ ICP.a.La } & Sample D25-8755 & $(24.3)$ & \multirow{2}{*}{$\begin{array}{c}<15.9 \\
\text { to } \\
24.3\end{array}$} & \multirow[t]{2}{*}{24.3} & \multirow[t]{2}{*}{ N/A } & \multirow[t]{8}{*}{14.8} \\
\hline & Sample D33-8755 & $(<15.9)$ & & & & \\
\hline \multirow{2}{*}{$\begin{array}{r}\text { Homogen. } \\
\text { Data }\end{array}$} & Sample D40-8755 & $1<16.0)$ & \multirow{2}{*}{$\begin{array}{l}<15.9 \\
\text { to } \\
<16.0\end{array}$} & \multirow[t]{2}{*}{$\cdots$} & \multirow[t]{2}{*}{--- } & \\
\hline & Sample D41-8755 & $(<15.9)$ & & & & \\
\hline \multirow[t]{2}{*}{ ICP.W.La } & Sample D25-7755 & $(<1.75)$ & \multirow{2}{*}{$\begin{array}{c}<1.75 \\
\text { to } \\
<16.4\end{array}$} & \multirow[t]{2}{*}{$<16.4$} & \multirow[t]{2}{*}{ N/A } & \\
\hline & Sample D33-7755 & $1<16.41$ & & & & \\
\hline \multirow[t]{2}{*}{ ICP.f.La } & Sample D25-6775 & $(<8.40)$ & \multirow{2}{*}{$\begin{array}{l}<8.40 \\
\text { to } \\
<8.47\end{array}$} & \multirow[t]{2}{*}{$<8.47$} & \multirow[t]{2}{*}{ N/A } & \\
\hline & Sample D33-6755 & $(<8.47)$ & & & & \\
\hline
\end{tabular}

Table A-1. Tank 241-T-105 Analytical Data: Lead

\begin{tabular}{|c|c|c|c|c|c|c|}
\hline Analyte & $\begin{array}{l}\text { Laboratory } \\
\text { Sample } \\
\text { Identification }\end{array}$ & $\begin{array}{c}\text { Analytical } \\
\text { Data } \\
\text { Result }\end{array}$ & $\begin{array}{c}\text { Range } \\
\text { of } \\
\text { Values }\end{array}$ & Mean & $\begin{array}{c}\text { Standard } \\
\text { Deviation } \\
\text { (Mean) }\end{array}$ & $\begin{array}{l}\text { Projected } \\
\text { Inventory }\end{array}$ \\
\hline Metal & & $\mu \mathrm{g} / \mathrm{g}$ & $\mu \mathrm{g} / \mathrm{g}$ & $\mu \mathrm{g} / \mathrm{g}$ & $\mu \mathrm{g} / \mathrm{g}$ & $\mathrm{kg}$ \\
\hline \multirow[t]{2}{*}{ ICP.a.Pb } & Sample D25-8755 & 799 & \multirow{2}{*}{$\begin{array}{c}269 \\
\text { to } \\
799\end{array}$} & \multirow[t]{2}{*}{534} & \multirow[t]{2}{*}{265} & \multirow[t]{8}{*}{325} \\
\hline & Sample D33-8755 & $(269)$ & & & & \\
\hline \multirow{2}{*}{$\begin{array}{r}\text { Homogen. } \\
\text { Dáta }\end{array}$} & Sample D40-8755 & $(266)$ & \multirow{2}{*}{$\begin{array}{c}266 \\
\text { to } \\
296\end{array}$} & \multirow[t]{2}{*}{--} & \multirow[t]{2}{*}{---} & \\
\hline & Sample D41-8755 & $(296)$ & & & & \\
\hline \multirow[t]{2}{*}{ ICP.w.Pb } & Sample D25-7755 & $(1.00)$ & \multirow{2}{*}{$\begin{array}{l}1.00 \\
\text { to } \\
48.3\end{array}$} & \multirow[t]{2}{*}{25.9} & \multirow[t]{2}{*}{17.7} & \\
\hline & Sample D33-7755 & $(48.3)$ & & & & \\
\hline \multirow[t]{2}{*}{ ICP.f.Pb } & Sample D25-6775 & 604 & \multirow{2}{*}{$\begin{array}{c}302 \\
\text { to } \\
604\end{array}$} & \multirow[t]{2}{*}{453} & \multirow[t]{2}{*}{151} & \\
\hline & Sample D33-6755 & 302 & & & & \\
\hline
\end{tabular}


Table A-1. Tank 241-T-105 Analytical Data: Lithium

\begin{tabular}{|c|c|c|c|c|c|c|}
\hline Analyte & $\begin{array}{c}\text { Laboratory } \\
\text { Sample } \\
\text { Idenitification }\end{array}$ & $\begin{array}{c}\text { Analytical } \\
\text { Data } \\
\text { Result } \\
\end{array}$ & $\begin{array}{c}\text { Range } \\
\text { of } \\
\text { Values }\end{array}$ & Mean & $\begin{array}{c}\text { Standard } \\
\text { Deviation } \\
\text { (Mean) } \\
\end{array}$ & $\begin{array}{l}\text { Projected } \\
\text { Inventory }\end{array}$ \\
\hline Metal & & $\mu \mathrm{g} / \mathrm{g}$ & $\mu \mathrm{g} / \mathrm{g}$ & $\mu \mathrm{g} / \mathrm{g}$ & $\mu \mathrm{g} / \mathrm{g}$ & $\mathrm{kg}$ \\
\hline \multirow[t]{2}{*}{ ICP.a.Li } & Sample D25-8755 & $(4.87)$ & \multirow{2}{*}{$\begin{array}{l}4.18 \\
\text { to } \\
4.87 \\
\end{array}$} & \multirow[t]{2}{*}{4.22} & \multirow[t]{2}{*}{0.226} & \multirow[t]{8}{*}{2.57} \\
\hline & Sample D33-8755 & 4.18 & & & & \\
\hline \multirow{2}{*}{$\begin{array}{r}\text { Homogen. } \\
\text { Data }\end{array}$} & Sample D40-8755 & $(<3.99)$ & \multirow{2}{*}{$\begin{array}{c}<3.99 \\
\text { to } \\
5.32 \\
\end{array}$} & \multirow[t]{2}{*}{--- } & \multirow[t]{2}{*}{---} & \\
\hline & Sample D41-8755 & $(5.32)$ & & & & \\
\hline \multirow[t]{2}{*}{ ICP.W.Li } & Sample D25-7755 & $(<0.411)$ & \multirow{2}{*}{$\begin{array}{l}<0.411 \\
\text { to } \\
<4.11 \\
\end{array}$} & \multirow[t]{2}{*}{$<4.11$} & \multirow[t]{2}{*}{ N/A } & \\
\hline & Sample D33-7755 & $(<4.11)$ & & & & \\
\hline \multirow[t]{2}{*}{ ICP.f.Li } & Sample D25-6775 & $(4.24)$ & \multirow{2}{*}{$\begin{array}{l}2.94 \\
\text { to } \\
4.24\end{array}$} & \multirow[t]{2}{*}{3.59} & \multirow[t]{2}{*}{0.650} & \\
\hline & Sample D33-6755 & $(2.94)$ & & & & \\
\hline
\end{tabular}

Table A-1. Tank 241-T-105 Analytical Data: Magnesium

\begin{tabular}{|c|c|c|c|c|c|c|}
\hline Analyte & $\begin{array}{c}\text { Laboratory } \\
\text { Sample } \\
\text { Identification }\end{array}$ & $\begin{array}{c}\text { Analytical } \\
\text { Data } \\
\text { Result }\end{array}$ & $\begin{array}{c}\text { Range } \\
\text { of } \\
\text { Values }\end{array}$ & Mean & $\begin{array}{c}\text { Standard } \\
\text { Deviation } \\
\text { (Mean) }\end{array}$ & $\begin{array}{l}\text { Projected } \\
\text { inventory }\end{array}$ \\
\hline Metal & & $\mu \mathrm{g} / \mathrm{g}$ & $\mu \mathrm{g} / \mathrm{g}$ & $\mu \mathrm{g} / \mathrm{g}$ & $\mu \mathrm{g} / \mathrm{g}$ & $\mathrm{kg}$ \\
\hline \multirow[t]{2}{*}{ ICP.a.Mg } & Sample D25-8755 & $(1,030)$ & \multirow{2}{*}{$\begin{array}{c}1,030 \\
\text { to } \\
1.100\end{array}$} & \multirow[t]{2}{*}{1,060} & \multirow[t]{2}{*}{44.8} & \multirow[t]{8}{*}{669} \\
\hline & Sample D33-8755 & 1,100 & & & & \\
\hline \multirow{2}{*}{$\begin{array}{r}\text { Homogen. } \\
\text { Data }\end{array}$} & Sample D40-8755 & $(1,000)$ & \multirow{2}{*}{$\begin{array}{c}1,000 \\
\text { to } \\
1,090\end{array}$} & \multirow[t]{2}{*}{--} & \multirow[t]{2}{*}{---} & \\
\hline & Sample D41-8755 & $(1,090)$ & & & & \\
\hline \multirow[t]{2}{*}{ ICP.w.Mg } & Sample D25-7755 & $(6.40)$ & \multirow{2}{*}{$\begin{array}{l}6.40 \\
\text { to } \\
22.4\end{array}$} & \multirow[t]{2}{*}{14.4} & \multirow[t]{2}{*}{8.00} & \\
\hline & Sample D33-7755 & $(22.4)$ & & & & \\
\hline \multirow[t]{2}{*}{ ICP.f.Mg } & Sample D25-6775 & $(1,250)$ & \multirow{2}{*}{$\begin{array}{c}957 \\
\text { to } \\
1,250 \\
\end{array}$} & \multirow[t]{2}{*}{1,100} & \multirow[t]{2}{*}{146} & \\
\hline & Sample D33-6755 & 957 & & & & \\
\hline
\end{tabular}


WHC-SD-WM-ER-369 REV O

Table A-1. Tank 241-T-105 Analytical Data: Manganese

\begin{tabular}{|c|c|c|c|c|c|c|}
\hline Analyte & $\begin{array}{l}\text { Laboratory } \\
\text { Sample } \\
\text { Identification }\end{array}$ & $\begin{array}{c}\text { Analytical } \\
\text { Data } \\
\text { Result }\end{array}$ & $\begin{array}{c}\text { Range } \\
\text { of } \\
\text { Values }\end{array}$ & Mean & $\begin{array}{c}\text { Standard } \\
\text { Deviation } \\
\text { (Mean) }\end{array}$ & $\begin{array}{l}\text { Projected } \\
\text { Inventory }\end{array}$ \\
\hline Metal & & $\mu \mathrm{g} / \mathrm{g}$ & $\mu \mathrm{g} / \mathrm{g}$ & $\mu \mathrm{g} / \mathrm{g}$ & $\mu \mathrm{g} / \mathrm{g}$ & $\mathrm{kg}$ \\
\hline \multirow[t]{2}{*}{ ICP.a.Mn } & Sample D25-8755 & 19,900 & \multirow{2}{*}{$\begin{array}{c}3,330 \\
\text { to } \\
19,900\end{array}$} & \multirow[t]{2}{*}{11,600} & \multirow[t]{2}{*}{8,260} & \multirow[t]{8}{*}{7,050} \\
\hline & Sample D33-8755 & 3,330 & & & & \\
\hline \multirow{2}{*}{$\begin{array}{r}\text { Homogen. } \\
\text { Data }\end{array}$} & Sample D40-8755 & $(2,900)$ & \multirow{2}{*}{$\begin{array}{c}2,900 \\
\text { to } \\
3,050\end{array}$} & \multirow[t]{2}{*}{--} & \multirow[t]{2}{*}{$\cdots$} & \\
\hline & Sample D41-8755 & $(3,050)$ & & & & \\
\hline \multirow[t]{2}{*}{ ICP.W.Mn } & Sample D25-7755 & $(0.859)$ & \multirow{2}{*}{$\begin{array}{c}0.859 \\
\text { to } \\
<3.08\end{array}$} & \multirow[t]{2}{*}{0.859} & \multirow[t]{2}{*}{ N/A } & \\
\hline & Sample D33-7755 & $1<3.08)$ & & & & \\
\hline \multirow[t]{2}{*}{ ICP.f.Mn } & Sample D25-6775 & $(17,900)$ & \multirow{2}{*}{$\begin{array}{c}2,810 \\
\text { to } \\
17,900\end{array}$} & \multirow[t]{2}{*}{10,400} & \multirow[t]{2}{*}{7,550} & \\
\hline & Sample D33-6755 & $(2,810)$ & & & & \\
\hline
\end{tabular}

Table A-1. Tank 241-T-105 Analytical Data: Mercury

\begin{tabular}{|c|c|c|c|c|c|c|}
\hline Analyte & $\begin{array}{l}\text { Laboratory } \\
\text { Sample } \\
\text { Identification }\end{array}$ & $\begin{array}{c}\text { Analytical } \\
\text { Data } \\
\text { Result }\end{array}$ & $\begin{array}{c}\text { Rangé } \\
\text { of } \\
\text { Values }\end{array}$ & Mean & $\begin{array}{c}\text { Standard } \\
\text { Deviation } \\
\text { (Mean) }\end{array}$ & $\begin{array}{l}\text { Projected } \\
\text { Inventory }\end{array}$ \\
\hline Metal & & $\mu \mathrm{g} / \mathrm{g}$ & $\mu \mathrm{g} / \mathrm{g}$ & $\mu \mathrm{g} / \mathrm{g}$ & $\mu \mathrm{g} / \mathrm{g}$ & $\mathrm{kg}$ \\
\hline \multirow[t]{2}{*}{ CVAA. Hg } & Sample D25-5798 & $(36.9)$ & \multirow{2}{*}{$\begin{array}{l}11.0 \\
\text { to } \\
36.9\end{array}$} & \multirow[t]{2}{*}{23.9} & \multirow[t]{2}{*}{12.9} & \multirow[t]{2}{*}{14.5} \\
\hline & Sample D33-5897 & 11.0 & & & & \\
\hline
\end{tabular}


Table A-1. Tank 241-T-105 Analytical Data: Molybdenum

\begin{tabular}{|c|c|c|c|c|c|c|}
\hline Analyte & $\begin{array}{c}\text { Laboratory } \\
\text { Sample- } \\
\text { Identification }\end{array}$ & $\begin{array}{c}\text { Analytical } \\
\text { Data } \\
\text { Result }\end{array}$ & $\begin{array}{c}\text { Range } \\
\text { of } \\
\text { Values }\end{array}$ & Mean & $\begin{array}{c}\text { Standard } \\
\text { Deviation } \\
\text { (Mean) }\end{array}$ & $\begin{array}{l}\text { Projected } \\
\text { Inventory }\end{array}$ \\
\hline Metal & & $\mu \mathrm{g} / \mathrm{g}$ & $\mu \mathrm{g} / \mathrm{g}$ & $\mu \mathrm{g} / \mathrm{g}$ & $\mu \mathrm{g} / \mathrm{g}$ & $\mathrm{kg}$ \\
\hline \multirow[t]{2}{*}{ ICP.a.Mo } & Sample D25-8755 & $(40.7)$ & \multirow{2}{*}{$\begin{array}{l}27.9 \\
\text { to } \\
40.7\end{array}$} & \multirow[t]{2}{*}{34.3} & \multirow[t]{2}{*}{6.40} & \multirow[t]{8}{*}{21.1} \\
\hline & Sample D33-8755 & $(27.9)$ & & & & \\
\hline \multirow{2}{*}{$\begin{array}{r}\text { Homogen. } \\
\text { Data }\end{array}$} & Sample D40-8755 & $(22.7)$ & \multirow{2}{*}{$\begin{array}{l}21.7 \\
\text { to } \\
22.7\end{array}$} & \multirow[t]{2}{*}{$\cdots$} & \multirow[t]{2}{*}{--} & \\
\hline & Sample D41-8755 & $(21.7)$ & & & & \\
\hline \multirow[t]{2}{*}{ ICP.w.Mo } & Sample D25-7755 & $(47.7)$ & \multirow{2}{*}{$\begin{array}{l}21.7 \\
\text { to } \\
47.7\end{array}$} & \multirow{2}{*}{$\begin{array}{r}34.7 \\
-\quad\end{array}$} & \multirow[t]{2}{*}{13.0} & \\
\hline & Sample D33-7755 & $(21.7)$ & & & & \\
\hline \multirow[t]{2}{*}{ ICP.f.Mo } & Sample D25-6775 & $(39.5)$ & \multirow{2}{*}{$\begin{array}{c}23.8 \\
\text { to } \\
39.5\end{array}$} & \multirow[t]{2}{*}{31.7} & \multirow[t]{2}{*}{7.85} & \\
\hline & Sample D33-6755 & $(23.8)$ & & & & \\
\hline
\end{tabular}

Table A-1. Tank 241-T-105 Analytical Data: Neodymium

\begin{tabular}{|c|c|c|c|c|c|c|}
\hline Analyte & $\begin{array}{l}\text { Laboratory } \\
\text { Sample } \\
\text { Identification }\end{array}$ & $\begin{array}{c}\text { Analytical } \\
\text { Data } \\
\text { Result }\end{array}$ & $\begin{array}{c}\text { Range } \\
\text { of } \\
\text { Values }\end{array}$ & Mean & $\begin{array}{c}\text { Standard } \\
\text { Deviation } \\
\text { (Mean) }\end{array}$ & $\begin{array}{l}\text { Projected } \\
\text { Inventory }\end{array}$ \\
\hline Metal & & $\mu \mathrm{g} / \mathrm{g}$ & $\mu \mathrm{g} / \mathrm{g}$ & $\mu \mathrm{g} / \mathrm{g}$ & $\mu \mathrm{g} / \mathrm{g}$ & $\mathrm{kg}$ \\
\hline \multirow[t]{2}{*}{ ICP.a.Nd } & Sample D25-8755 & 152 & \multirow{2}{*}{$\begin{array}{c}<59.7 \\
\text { to } \\
152\end{array}$} & \multirow[t]{2}{*}{152} & \multirow[t]{2}{*}{ N/A } & \multirow[t]{8}{*}{92.4} \\
\hline & Sample D33-8755 & $<59.7$ & & & & \\
\hline \multirow{2}{*}{$\begin{array}{r}\text { Homogen. } \\
\text { Data }\end{array}$} & Sample D40-8755 & $|<59.9|$ & \multirow{2}{*}{$\begin{array}{c}<9.9 \\
\text { to } \\
73.4\end{array}$} & \multirow[t]{2}{*}{--} & \multirow[t]{2}{*}{--} & \\
\hline & Sample D41-8755 & $(73.4)$ & & & & \\
\hline \multirow[t]{2}{*}{ ICP.w.Nd } & Sample D25-7755 & $|<8.43|$ & \multirow{2}{*}{$\begin{array}{c}<8.43 \\
\text { to } \\
<61.6\end{array}$} & \multirow[t]{2}{*}{$<61.6$} & \multirow[t]{2}{*}{ N/A } & \\
\hline & Sample D33-7755 & $(<61.6)$ & & & & \\
\hline \multirow[t]{2}{*}{ ICP.f.Nd } & Sample D25-6775 & $(110)$ & \multirow{2}{*}{$\begin{array}{c}40.6 \\
\text { to } \\
110\end{array}$} & \multirow[t]{2}{*}{75.4} & \multirow[t]{2}{*}{34.6} & \\
\hline & Sample D33-6755 & $(40.6)$ & & & & \\
\hline
\end{tabular}


WHC-SD-WM-ER-369 REV 0

Table A-1. Tank 241-T-105 Analytical Data: Nickel

\begin{tabular}{|c|c|c|c|c|c|c|}
\hline Analyte & $\begin{array}{l}\text { Laboratory } \\
\text { Sample } \\
\text { Identification }\end{array}$ & $\begin{array}{c}\text { Analytical } \\
\text { Data } \\
\text { Result }\end{array}$ & $\begin{array}{c}\text { Range } \\
\text { of } \\
\text { Values }\end{array}$ & Mean & $\begin{array}{c}\text { Standard } \\
\text { Deviation } \\
\text { (Mean }\end{array}$ & $\begin{array}{l}\text { Projected } \\
\text { Inventory }\end{array}$ \\
\hline Metal & & $\mu \mathrm{g} / \mathrm{g}$ & $\mu \mathrm{g} / \mathrm{g}$ & $\mu \mathrm{g} / \mathrm{g}$ & $\mu \mathrm{g} / \mathrm{g}$ & $\mathrm{kg}$ \\
\hline \multirow[t]{2}{*}{ ICP.a.Ni } & Sample D25-8755 & 96.7 & \multirow{2}{*}{$\begin{array}{c}66.1 \\
\text { to } \\
96.7\end{array}$} & \multirow[t]{2}{*}{81.3} & \multirow[t]{2}{*}{15.3} & \multirow[t]{6}{*}{49.4} \\
\hline & Sample D33-8755 & 66.1 & & & & \\
\hline \multirow{2}{*}{$\begin{array}{r}\text { Homogen. } \\
\text { Data }\end{array}$} & Sample D40-8755 & $(56.8)$ & \multirow{2}{*}{$\begin{array}{l}56.8 \\
\text { to } \\
67.8\end{array}$} & \multirow[t]{2}{*}{---} & \multirow[t]{2}{*}{---} & \\
\hline & Sample D41-8755 & $(67.8)$ & & & & \\
\hline \multirow[t]{2}{*}{ ICP.W.Ni } & Sample D25-7755 & $(13.9)$ & \multirow{2}{*}{$\begin{array}{l}11.5 \\
\text { to } \\
13.9\end{array}$} & \multirow[t]{2}{*}{12.7} & \multirow[t]{2}{*}{1.25} & \\
\hline & Sample D33-7755 & $(11.5)$ & & & & \\
\hline
\end{tabular}

Table A-1. Tank 241-T-105 Analytical Data: Phosphorus

\begin{tabular}{|c|c|c|c|c|c|c|}
\hline Analyte & $\begin{array}{l}\text { Laboratory } \\
\text { Sample } \\
\text { Identification }\end{array}$ & $\begin{array}{c}\text { Analytical } \\
\text { Data } \\
\text { Result }\end{array}$ & $\begin{array}{c}\text { Range } \\
\text { of } \\
\text { Values }\end{array}$ & Mean & $\begin{array}{c}\text { Standard } \\
\text { Deviation } \\
\text { (Mean) }\end{array}$ & $\begin{array}{l}\text { Projected } \\
\text { Inventory }\end{array}$ \\
\hline Metal & & $\mu \mathrm{g} / \mathrm{g}$ & $\mu \mathrm{g} / \mathrm{g}$ & $\mu \mathrm{g} / \mathrm{g}$ & $\mu \mathrm{g} / \mathrm{g}$ & $\mathrm{kg}$ \\
\hline \multirow[t]{2}{*}{ ICP.a.P } & Sample D25-8755 & 1,810 & \multirow{2}{*}{$\begin{array}{c}1,180 \\
\text { to } \\
1,8410\end{array}$} & \multirow[t]{2}{*}{1,490} & \multirow[t]{2}{*}{313} & \multirow[t]{8}{*}{930} \\
\hline & Sample D33-8755 & $(1,180)$ & & & & \\
\hline \multirow{2}{*}{$\begin{array}{r}\text { Homogen. } \\
\text { Data }\end{array}$} & Sample D40-8755 & $(1,080)$ & \multirow{2}{*}{$\begin{array}{c}1,080 \\
\text { to } \\
1,130\end{array}$} & \multirow[t]{2}{*}{--} & \multirow[t]{2}{*}{--- } & \\
\hline & Sample D41-8755 & $(1,130)$ & & & & \\
\hline \multirow[t]{2}{*}{ ICP.w.P } & Sample D25-7755 & $(891)$ & \multirow{2}{*}{$\begin{array}{l}419 \\
\text { to } \\
891\end{array}$} & \multirow[t]{2}{*}{655} & \multirow[t]{2}{*}{236} & \\
\hline & Sample D33-7755 & $(419)$ & & & & \\
\hline \multirow[t]{2}{*}{ ICP.f.P } & Sample D25-6775 & $(1,960)$ & \multirow{2}{*}{$\begin{array}{c}1,110 \\
\text { to } \\
1,960\end{array}$} & \multirow[t]{2}{*}{1,530} & \multirow[t]{2}{*}{423} & \\
\hline & Sample D33-6755 & $(1,110)$ & & & & \\
\hline
\end{tabular}


Table A-1. Tank 241-T-105 Analytical Data: Potassium

\begin{tabular}{|c|c|c|c|c|c|c|}
\hline Analyte. & $\begin{array}{c}\text { Laboratory } \\
\text { Sample } \\
\text { Identification }\end{array}$ & $\begin{array}{c}\text { Analytical } \\
\text { Data } \\
\text { Result }\end{array}$ & $\begin{array}{c}\text { Range } \\
\text { of } \\
\text { Values }\end{array}$ & Mean & $\begin{array}{l}\text { Standard } \\
\text { Deviation } \\
\text { (Mean) }\end{array}$ & $\begin{array}{l}\text { Projected } \\
\text { Inventory }\end{array}$ \\
\hline Metal & & $\mu g / g$ & $\mu \mathrm{g} / \mathrm{g}$ & $\mu \mathrm{g} / \mathrm{g}$ & $\mu \mathrm{g} / \mathrm{g}$ & $\mathrm{kg}$ \\
\hline \multirow[t]{2}{*}{ ICP.a.K } & Sample D25-8755 & $(398)$ & \multirow{2}{*}{$\begin{array}{l}213 \\
\text { to } \\
398\end{array}$} & \multirow[t]{2}{*}{305} & \multirow[t]{2}{*}{92.5} & \multirow[t]{6}{*}{185} \\
\hline & Sample D33-8755 & 213 & & & & \\
\hline \multirow{2}{*}{$\begin{array}{r}\text { Homogen. } \\
\text { Data }\end{array}$} & Sample D40-8755 & $(254)$ & \multirow{2}{*}{$\begin{array}{l}183 \\
\text { to } \\
254\end{array}$} & \multirow[t]{2}{*}{.---} & \multirow[t]{2}{*}{---} & \\
\hline & Sample D41-8755 & $(183)$ & & & & \\
\hline \multirow[t]{2}{*}{ ICP.W.K } & Sample D25-7755 & 373 & \multirow{2}{*}{$\begin{array}{l}179 \\
\text { to } \\
373\end{array}$} & \multirow[t]{2}{*}{276} & \multirow[t]{2}{*}{97.0} & \\
\hline & Sample D33-7755 & $(179)$ & & & & \\
\hline
\end{tabular}

Table A-1. Tank 241-T-105 Analytical Data: Samarium

\begin{tabular}{|c|c|c|c|c|c|c|}
\hline Analyte & $\begin{array}{l}\text { Laboratory } \\
\text { Sample } \\
\text { Identification }\end{array}$ & $\begin{array}{c}\text { Analytical } \\
\text { Data } \\
\text { Resuit }\end{array}$ & $\begin{array}{c}\text { Range } \\
\text { of } \\
\text { Values }\end{array}$ & Mean & $\begin{array}{c}\text { Standard } \\
\text { Deviation } \\
\text { (Mean) }\end{array}$ & $\begin{array}{l}\text { Projected } \\
\text { Inventory }\end{array}$ \\
\hline Metal & & $\mu \mathrm{g} / \mathrm{g}$ & $\mu \mathrm{g} / \mathrm{g}$ & $\mu \mathrm{g} / \mathrm{g}$ & $\mu \mathrm{g} / \mathrm{g}$ & $\mathrm{kg}$ \\
\hline \multirow[t]{2}{*}{ ICP.a.Sm } & Sample D25-8755 & $<43.1$ & \multirow{2}{*}{$\begin{array}{c}<43.1 \\
\text { to } \\
56.4\end{array}$} & \multirow[t]{2}{*}{56.4} & \multirow[t]{2}{*}{$N / A$} & \multirow[t]{8}{*}{42.8} \\
\hline & Sample D33-8755 & $(56.4)$ & & & & \\
\hline \multirow{2}{*}{$\begin{array}{r}\text { Homogen. } \\
\text { Data }\end{array}$} & Sample D40-8755 & $(63.8)$ & \multirow{2}{*}{$\begin{array}{c}63.8 \\
\text { to } \\
96.8\end{array}$} & \multirow[t]{2}{*}{--} & \multirow[t]{2}{*}{--} & \\
\hline & Sample D41-8755 & $(86.8)$ & & & & \\
\hline \multirow[t]{2}{*}{ ICP.w.Sm } & Sample D25-7755 & $1<9.66)$ & \multirow{2}{*}{$\begin{array}{c}<9.66 \\
\text { to } \\
<45.2 \\
\end{array}$} & \multirow[t]{2}{*}{$<45.2$} & \multirow[t]{2}{*}{ N/A } & \\
\hline & Sample D33-7755 & $1<45.21$ & & & & \\
\hline \multirow[t]{2}{*}{ ICP.f.Sm } & Sample D25-6775 & $(86.8)$ & \multirow{2}{*}{$\begin{array}{l}61.9 \\
\text { to } \\
86.8\end{array}$} & \multirow[t]{2}{*}{70.4} & \multirow[t]{2}{*}{16.4} & \\
\hline & Sample D33-6755 & $(61.9)$ & & & & \\
\hline
\end{tabular}


WHC-SD-WM-ER-369 REV O

Table A-1. Tank 241-T-105 Analytical Data: Selenium

\begin{tabular}{|c|c|c|c|c|c|c|}
\hline Analyte & $\begin{array}{l}\text { Laboratory } \\
\text { Sample } \\
\text { Identification }\end{array}$ & $\begin{array}{c}\text { Analytical } \\
\text { Data } \\
\text { Result }\end{array}$ & $\begin{array}{c}\text { Range } \\
\text { of } \\
\text { Values }\end{array}$ & Mean & $\begin{array}{c}\text { Standard } \\
\text { Deviation } \\
\text { (Mean) }\end{array}$ & $\begin{array}{l}\text { Projected } \\
\text { Inventory }\end{array}$ \\
\hline Metal & & $\mu \mathrm{g} / \mathrm{g}$ & $\mu \mathrm{g} / \mathrm{g}$ & $\mu \mathrm{g} / \mathrm{g}$ & $\mu \mathrm{g} / \mathrm{g}$ & $\mathrm{kg}$ \\
\hline \multirow[t]{2}{*}{ ICP.a.Se } & Sample D25-8755 & $<61.8$ & \multirow[t]{2}{*}{ N/A } & \multirow[t]{2}{*}{$\cdots$} & \multirow[t]{2}{*}{--} & \multirow[t]{8}{*}{45.4} \\
\hline & Sample D33-8755 & $<62.7$ & & & & \\
\hline \multirow{2}{*}{$\begin{array}{r}\text { Homogen. } \\
\text { Data }\end{array}$} & Sample D40-8755 & $(<62.9)$ & \multirow{2}{*}{$\begin{array}{c}<62.6 \\
\text { to } \\
<62.9\end{array}$} & \multirow[t]{2}{*}{--} & \multirow[t]{2}{*}{--} & \\
\hline & Sample D41-8755 & $(<62.6)$ & & & & \\
\hline \multirow[t]{2}{*}{ ICP.w.Se } & Sample D25-7755 & $<8.94$ & \multirow{2}{*}{$\begin{array}{c}<8.94 \\
\text { to } \\
74.7\end{array}$} & \multirow[t]{2}{*}{74.7} & \multirow[t]{2}{*}{ N/A } & \\
\hline & Sample D33-7755 & $(74.7)$ & & & & \\
\hline \multirow[t]{2}{*}{ ICP.f.Se } & Sample D25-6775 & $(<43.0)$ & \multirow{2}{*}{$\begin{array}{c}<43.0 \\
\text { to } \\
<43.3 \\
\end{array}$} & \multirow[t]{2}{*}{$<43.3$} & \multirow[t]{2}{*}{ N/A } & \\
\hline & Sample D33-6755 & $(<43.3)$ & & & & \\
\hline
\end{tabular}

Table A-1. Tank 241-T-105 Analytical Data: Silicon

\begin{tabular}{|c|c|c|c|c|c|c|}
\hline Analyte & $\begin{array}{l}\text { Laboratory } \\
\text { Sample } \\
\text { Identification }\end{array}$ & $\begin{array}{c}\text { Analytical } \\
\text { Data } \\
\text { Result }\end{array}$ & $\begin{array}{c}\text { Range } \\
\text { of } \\
\text { Values }\end{array}$ & Mean & $\begin{array}{c}\text { Standard } \\
\text { Deviation } \\
\text { (Mean) }\end{array}$ & $\begin{array}{l}\text { Projected } \\
\text { Inventory }\end{array}$ \\
\hline Metal & & $\mu \mathrm{g} / \mathrm{g}$ & $\mu \mathrm{g} / \mathrm{g}$ & $\mu \mathrm{g} / \mathrm{g}$ & $\mu \mathrm{g} / \mathrm{g}$ & $\mathrm{kg}$ \\
\hline \multirow[t]{2}{*}{ ICP.a.Si } & Sample D25-8755 & $(2,250)$ & \multirow{2}{*}{$\begin{array}{c}72.5 \\
\text { to } \\
2,250 \\
\end{array}$} & \multirow[t]{2}{*}{1,160} & \multirow[t]{2}{*}{1,090} & \multirow[t]{8}{*}{4,200} \\
\hline & Sample D33-8755 & $(72.5)$ & & & & \\
\hline \multirow{2}{*}{$\begin{array}{r}\text { Homogen. } \\
\text { Data }\end{array}$} & Sample D40-8755 & $(230)$ & \multirow{2}{*}{$\begin{array}{c}230 \\
\text { to } \\
288\end{array}$} & \multirow[t]{2}{*}{---} & \multirow[t]{2}{*}{---} & \\
\hline & Sample D41-8755 & $(288)$ & & & & \\
\hline \multirow[t]{2}{*}{ ICP.w.Si } & Sample D25-7755 & $(490)$ & \multirow{2}{*}{$\begin{array}{c}490 \\
\text { to } \\
1,000\end{array}$} & \multirow[t]{2}{*}{747} & \multirow[t]{2}{*}{257} & \\
\hline & Sample D33-7755 & $(1,000)$ & & & & \\
\hline \multirow[t]{2}{*}{ ICP.f.Si } & Sample D25-6775 & $(7,760)$ & \multirow{2}{*}{$\begin{array}{c}6,200 \\
\text { to } \\
7,760\end{array}$} & \multirow[t]{2}{*}{6.980} & \multirow[t]{2}{*}{784} & \\
\hline & Sample D33-6755 & 6,200 & & & & \\
\hline
\end{tabular}


Table A-1. Tank 241-T-105 Analytical Data: Silver

\begin{tabular}{|c|c|c|c|c|c|c|}
\hline Analyte & $\begin{array}{l}\text { Laboratory } \\
\text { Sample } \\
\text { Identification }\end{array}$ & $\begin{array}{c}\text { Analytical } \\
\text { Data } \\
\text { Result }\end{array}$ & $\begin{array}{c}\text { Range. } \\
\text { of } \\
\text { Values }\end{array}$ & Mean & $\begin{array}{c}\text { Standard } \\
\text { Deviation } \\
\text { (Mean) }\end{array}$ & $\begin{array}{l}\text { Projected } \\
\text { Inventory }\end{array}$ \\
\hline Metal & & $\mu \mathrm{g} / \mathrm{g}$ & $\mu g / g$ & $\mu \mathrm{g} / \mathrm{g}$ & $\mu \mathrm{g} / \mathrm{g}$ & $\mathrm{kg}$ \\
\hline \multirow[t]{2}{*}{ ICP.a.Ag } & Sample D25-8755 & 13.4 & \multirow[t]{2}{*}{ N/A } & \multirow[t]{2}{*}{19.8} & \multirow[t]{2}{*}{ N/A } & \multirow[t]{8}{*}{28.1} \\
\hline & Sample D33-8755 & $(19.8)$ & & & & \\
\hline \multirow{2}{*}{$\begin{array}{r}\text { Homogen. } \\
\text { Data }\end{array}$} & Sample D40-8755 & $(19.0)$ & \multirow{2}{*}{$\begin{array}{l}18.9 \\
\text { to } \\
19.0\end{array}$} & \multirow[t]{2}{*}{--} & \multirow[t]{2}{*}{$\cdots$} & \\
\hline & Sample D41-8755 & $(18.9)$ & & & & \\
\hline \multirow[t]{2}{*}{ ICP.w.Ag } & Sample D25-7755 & $(5.16)$ & \multirow{2}{*}{$\begin{array}{c}5.16 \\
\text { to } \\
<6.16\end{array}$} & \multirow[t]{2}{*}{5.16} & \multirow[t]{2}{*}{ N/A } & \\
\hline & Sample D33-7755 & $(<6.16)$ & & & & \\
\hline \multirow[t]{2}{*}{ ICP.f.Ag } & Sample D25-6775 & 69.3 & \multirow{2}{*}{$\begin{array}{l}23.1 \\
\text { to } \\
69.3\end{array}$} & \multirow[t]{2}{*}{46.2} & \multirow[t]{2}{*}{23.1} & \\
\hline & Sample D33-6755 & $(23.1)$ & & & & \\
\hline
\end{tabular}

Table A-1. Tank 241-T-105 Analytical Data: Sodium

\begin{tabular}{|c|c|c|c|c|c|c|}
\hline Analyte & $\begin{array}{l}\text { Laboratory } \\
\text { Sample } \\
\text { Identification }\end{array}$ & $\begin{array}{c}\text { Analytical } \\
\text { Data } \\
\text { Result }\end{array}$ & $\begin{array}{c}\text { Range } \\
\text { of } \\
\text { Values }\end{array}$ & Mean & $\begin{array}{c}\text { Standard } \\
\text { Deviation } \\
\text { (Mean) }\end{array}$ & $\begin{array}{l}\text { Projected } \\
\text { Inventory }\end{array}$ \\
\hline Metal & & $\mu \mathrm{g} / \mathrm{g}$ & $\mu \mathrm{g} / \mathrm{g}$ & $\mu \mathrm{g} / \mathrm{g}$ & $\mu \mathrm{g} / \mathrm{g}$ & $\mathrm{kg}$ \\
\hline \multirow[t]{2}{*}{ ICP.a.Na } & Sample D25-8755 & $(68,600)$ & \multirow{2}{*}{$\begin{array}{c}44,100 \\
\text { to } \\
68,600\end{array}$} & \multirow[t]{2}{*}{56,300} & \multirow[t]{2}{*}{12,300} & \multirow[t]{8}{*}{34,200} \\
\hline & Sample D33-8755 & $(44,100)$ & & & & \\
\hline \multirow{2}{*}{$\begin{array}{r}\text { Homogen. } \\
\text { Data }\end{array}$} & Sample D40-8755 & $(40,100)$ & \multirow{2}{*}{$\begin{array}{c}40,100 \\
\text { to } \\
42,400\end{array}$} & \multirow[t]{2}{*}{---} & \multirow[t]{2}{*}{$\cdots$} & \\
\hline & Sample D41-8755 & $(42,400)$ & & & & \\
\hline \multirow[t]{2}{*}{ ICP.w.Na } & Sample D25-7755 & $(60,400)$ & \multirow{2}{*}{$\begin{array}{c}38,300 \\
\text { to } \\
60,400\end{array}$} & \multirow[t]{2}{*}{49,500} & \multirow[t]{2}{*}{11,100} & \\
\hline & Sample D33-7755 & $(38,300)$ & & & & \\
\hline \multirow[t]{2}{*}{ ICP.f. $\mathrm{Na}$} & Sample D25-6775 & $(62,100)$ & \multirow{2}{*}{$\begin{array}{c}39,500 \\
\text { to } \\
62,100\end{array}$} & \multirow[t]{2}{*}{49,200} & \multirow[t]{2}{*}{12,900} & \\
\hline & Sample D33-6755 & $(39,500)$ & & & & \\
\hline
\end{tabular}


WHC-SD-WM-ER-369 REV O

Table A-1. Tank 241-T-105 Analytical Data: Strontium

\begin{tabular}{|c|c|c|c|c|c|c|}
\hline Analyte & $\begin{array}{c}\text { Laboratory } \\
\text { Sample } \\
\text { Identification }\end{array}$ & $\begin{array}{c}\text { Analytical } \\
\text { Data } \\
\text { Result }\end{array}$ & $\begin{array}{c}\text { Range } \\
\text { of } \\
\text { Values }\end{array}$ & Mean & $\begin{array}{c}\text { Standard } \\
\text { Deviation } \\
\text { (Mean) }\end{array}$ & $\begin{array}{l}\text { Projected } \\
\text { Inventory }\end{array}$ \\
\hline Metal & & $\mu \mathrm{g} / \mathrm{g}$ & $\mu \mathrm{g} / \mathrm{g}$ & $\mu \mathrm{g} / \mathrm{g}$ & $\mu \mathrm{g} / \mathrm{g}$ & $\mathrm{kg}$ \\
\hline \multirow[t]{2}{*}{ ICP.a.Sr } & Sample D25-8755 & 128 & \multirow{2}{*}{$\begin{array}{l}128 \\
\text { to } \\
167\end{array}$} & \multirow[t]{2}{*}{148} & \multirow[t]{2}{*}{19.0} & \multirow[t]{8}{*}{90.0} \\
\hline & Sample D33-8755 & 167 & & & & \\
\hline \multirow{2}{*}{$\begin{array}{r}\text { Homogen. } \\
\text { Data }\end{array}$} & Sample D40-8755 & $(156)$ & \multirow{2}{*}{$\begin{array}{c}156 \\
\text { to } \\
164\end{array}$} & \multirow[t]{2}{*}{--} & \multirow[t]{2}{*}{$-\cdots$} & \\
\hline & Sample D41-8755 & $(164)$ & & & & \\
\hline \multirow[t]{2}{*}{ ICP.w.Sr } & Sample D25-7755 & $(0.980)$ & \multirow{2}{*}{$\begin{array}{c}0.980 \\
\text { to } \\
<3.08\end{array}$} & \multirow[t]{2}{*}{0.980} & \multirow[t]{2}{*}{ N/A } & \\
\hline & Sample D33-7755 & $1<3.08)$ & & & & \\
\hline \multirow[t]{2}{*}{ ICP.f.Sr } & Sample D25-6775 & $(129)$ & \multirow{2}{*}{$\begin{array}{c}129 \\
\text { to } \\
153 \\
\end{array}$} & \multirow[t]{2}{*}{141} & \multirow[t]{2}{*}{11.7} & \\
\hline & Sample D33-6755 & $(153)$ & & & & \\
\hline
\end{tabular}

Table A-1. Tank 241-T-105 Analytical Data: Sulfur

\begin{tabular}{|c|c|c|c|c|c|c|}
\hline Analyte & $\begin{array}{l}\text { Laboratory } \\
\text { Sample } \\
\text { Identification }\end{array}$ & $\begin{array}{c}\text { Analytical } \\
\text { Data } \\
\text { Result }\end{array}$ & $\begin{array}{c}\text { Range } \\
\text { of } \\
\text { Values }\end{array}$ & Mean & $\begin{array}{c}\text { Standard } \\
\text { Deviation } \\
\text { (Mean) }\end{array}$ & $\begin{array}{l}\text { Projected } \\
\text { Inventory }\end{array}$ \\
\hline Metal & & $\mu \mathrm{g} / \mathrm{g}$ & $\mu \mathrm{g} / \mathrm{g}$ & $\mu \mathrm{g} / \mathrm{g}$ & $\mu \mathrm{g} / \mathrm{g}$ & $\mathrm{kg}$ \\
\hline \multirow[t]{2}{*}{ ICP.a.S } & Sample D25-8755 & 3,310 & \multirow{2}{*}{$\begin{array}{c}1,900 \\
\text { to } \\
3,310\end{array}$} & \multirow[t]{2}{*}{2,610} & \multirow[t]{2}{*}{705} & \multirow[t]{8}{*}{1,680} \\
\hline & Sample D33-8755 & 1,900 & & & & \\
\hline \multirow{2}{*}{$\begin{array}{r}\text { Homogen. } \\
\text { Data }\end{array}$} & Sample D40-8755 & $(1,730)$ & \multirow{2}{*}{$\begin{array}{c}1,730 \\
\text { to } \\
1,910\end{array}$} & \multirow[t]{2}{*}{$\cdots$} & \multirow[t]{2}{*}{--} & \\
\hline & Sample D41-8755 & $(1,910)$ & & & & \\
\hline \multirow[t]{2}{*}{ ICP.w.S } & Sample D25-7755 & $(3,460)$ & \multirow{2}{*}{$\begin{array}{c}2,060 \\
\text { to } \\
3,460\end{array}$} & \multirow[t]{2}{*}{2,760} & \multirow[t]{2}{*}{700} & \\
\hline & Sample D33-7755 & $(2,060)$ & & & & \\
\hline \multirow[t]{2}{*}{ ICP.f.S } & Sample D25-6775 & $(3,470)$ & \multirow{2}{*}{$\begin{array}{c}1,770 \\
\text { to } \\
3,470\end{array}$} & \multirow[t]{2}{*}{2,620} & \multirow[t]{2}{*}{850} & \\
\hline & Sample D33-6755 & $(1,770)$ & & & & \\
\hline
\end{tabular}


Table A-1. Tank 241-T-105 Analytical Data: Thallium

\begin{tabular}{|c|c|c|c|c|c|c|}
\hline Analyte & $\begin{array}{c}\text { Laboratory } \\
\text { Sample } \\
\text { Identification }\end{array}$ & $\begin{array}{c}\text { Analytical } \\
\text { Data } \\
\text { Result }\end{array}$ & $\begin{array}{c}\text { Range } \\
\text { of } \\
\text { Values }\end{array}$ & Mean & $\begin{array}{c}\text { Standard } \\
\text { Deviation } \\
\text { (Mean) }\end{array}$ & $\begin{array}{l}\text { Projected } \\
\text { Inventory }\end{array}$ \\
\hline Metal & & $\mu \mathrm{g} / \mathrm{g}$ & $\mu g / g$ & $\mu \mathrm{g} / \mathrm{g}$ & $\mu \mathrm{g} / \mathrm{g}$ & $\mathrm{kg}$ \\
\hline \multirow[t]{2}{*}{ ICP.a.TI } & Sample D25-8755 & $(<79.4)$ & \multirow{2}{*}{$\begin{array}{c}<9.4 \\
\text { to } \\
101\end{array}$} & \multirow[t]{2}{*}{101} & \multirow[t]{2}{*}{ N/A } & \multirow[t]{8}{*}{61.4} \\
\hline & Sample D33-8755 & $(101)$ & & & & \\
\hline \multirow{2}{*}{$\begin{array}{r}\text { Homogen. } \\
\text { Data }\end{array}$} & Sample D40-8755 & $(91.9)$ & \multirow{2}{*}{$\begin{array}{c}80.4 \\
\text { to } \\
91.9\end{array}$} & \multirow[t]{2}{*}{$\cdots$} & \multirow[t]{2}{*}{--} & \\
\hline & Sample D41-8755 & $(<80.4)$ & & & & \\
\hline \multirow[t]{2}{*}{ ICP.W.TI } & Sample D25-7755 & $\mid<16.9)$ & \multirow{2}{*}{$\begin{array}{l}<16.9 \\
\text { to } \\
<83.2 \\
\end{array}$} & \multirow[t]{2}{*}{$<83.2$} & \multirow[t]{2}{*}{ N/A } & \\
\hline & Sample D33-7755 & $|<83.2|$ & & & & \\
\hline \multirow[t]{2}{*}{ ICP.f.TI } & Sample D25-6775 & $1<81.01$ & \multirow{2}{*}{$\begin{array}{l}<81.0 \\
\text { to } \\
<81.7 \\
\end{array}$} & \multirow[t]{2}{*}{$<81.7$} & \multirow[t]{2}{*}{ N/A } & \\
\hline & Sâmple D33-6755 & $(<81.7)$ & & & & \\
\hline
\end{tabular}

Table A-1. Tank 241-T-105 Analytical Data: Titanium

\begin{tabular}{|c|c|c|c|c|c|c|}
\hline Analyte & $\begin{array}{l}\text { Laboratory } \\
\text { Sample } \\
\text { Identification }\end{array}$ & $\begin{array}{c}\text { Analytical } \\
\text { Data } \\
\text { Result }\end{array}$ & $\begin{array}{c}\text { Range } \\
\text { of } \\
\text { Values }\end{array}$ & Mean & $\begin{array}{c}\text { Standard } \\
\text { Deviation } \\
\text { (Mean) }\end{array}$ & $\begin{array}{l}\text { Projected } \\
\text { Inventory }\end{array}$ \\
\hline Metal & & $\mu \mathrm{g} / \mathrm{g}$ & $\mu \mathrm{g} / \mathrm{g}$ & $\mu \mathrm{g} / \mathrm{g}$ & $\mu \mathrm{g} / \mathrm{g}$ & $\mathrm{kg}$ \\
\hline \multirow[t]{2}{*}{ IC8.a.Ti } & Sample D25-8755 & $(68.0)$ & \multirow{2}{*}{$\begin{array}{l}49.6 \\
\text { to } \\
68.0\end{array}$} & \multirow[t]{2}{*}{58.8} & \multirow[t]{2}{*}{9.18} & \multirow[t]{8}{*}{139} \\
\hline & Sample D33-8755 & 49.6 & & & & \\
\hline \multirow{2}{*}{$\begin{array}{r}\text { Homogen. } \\
\text { Data }\end{array}$} & Sample D40-8755 & $(44.8)$ & \multirow{2}{*}{$\begin{array}{c}44.8 \\
\text { to } \\
47.9\end{array}$} & \multirow[t]{2}{*}{$\cdots$} & \multirow[t]{2}{*}{$\cdots$} & \\
\hline & Sample D41-8755 & $(47.9)$ & & & & \\
\hline \multirow[t]{2}{*}{ ICP.W.Ti } & Sample D25-7755 & $<0.308$ & \multirow{2}{*}{$\begin{array}{c}<0.308 \\
\text { to } \\
<3.08\end{array}$} & \multirow[t]{2}{*}{$<3.08$} & \multirow[t]{2}{*}{$N / A$} & \\
\hline & Sample D33-7755 & $(<3.08)$ & & & & \\
\hline \multirow[t]{2}{*}{ ICP.f.Ti } & Sample D25-6775 & $(371)$ & \multirow{2}{*}{$\begin{array}{l}84.0 \\
\text { to } \\
371\end{array}$} & \multirow[t]{2}{*}{228} & \multirow[t]{2}{*}{144} & \\
\hline & Sample D33-6755 & $(84.0)$ & & & & \\
\hline
\end{tabular}


Table A-1. Tank 241-T-105 Analytical Data: Uranium

\begin{tabular}{|c|c|c|c|c|c|c|}
\hline Analyte & $\begin{array}{l}\text { Laboratory } \\
\text { Sample } \\
\text { Identification }\end{array}$ & $\begin{array}{c}\text { Analytical } \\
\text { Data } \\
\text { Result }\end{array}$ & $\begin{array}{c}\text { Range } \\
\text { of } \\
\text { Values }\end{array}$ & Mean & $\begin{array}{c}\text { Standard } \\
\text { Deviation } \\
\text { (Mean) }\end{array}$ & $\begin{array}{l}\text { Projected } \\
\text { Inventory }\end{array}$ \\
\hline Metal & & $\mu \mathrm{g} / \mathrm{mL}$ & $\mu \mathrm{g} / \mathrm{mL}$ & $\mu \mathrm{g} / \mathrm{mL}$ & $\mu \mathrm{g} / \mathrm{mL}$ & $\mathrm{kg}$ \\
\hline \multirow[t]{2}{*}{ LF.d.U } & Sample D19-5740 & $(7.75)$ & N/A & 7.75 & N/A & \multirow[t]{4}{*}{5,550} \\
\hline & & $\mu \mathrm{g} / \mathrm{g}$ & $\mu \mathrm{g} / \mathrm{g}$ & $\mu \mathrm{g} / \mathrm{g}$ & $\mu \mathrm{g} / \mathrm{g}$ & \\
\hline \multirow[t]{2}{*}{ LF.f.U } & Sample D25-6740 & $(8,740)$ & \multirow{2}{*}{$\begin{array}{c}8,740 \\
\text { to } \\
9,500\end{array}$} & \multirow[t]{2}{*}{9,120} & \multirow[t]{2}{*}{ N/A } & \\
\hline & Sample D33-6740 & $(9,500)$ & & & & \\
\hline
\end{tabular}

Table A-1. Tank 241-T-105 Analytical Data: Zirconium

\begin{tabular}{|c|c|c|c|c|c|c|}
\hline Analyte & $\begin{array}{l}\text { Laboratory } \\
\text { Sample } \\
\text { Identification }\end{array}$ & $\begin{array}{c}\text { Analytical } \\
\text { Data } \\
\text { Result }\end{array}$ & $\begin{array}{c}\text { Range } \\
\text { of } \\
\text { Values }\end{array}$ & Mean & $\begin{array}{c}\text { Standard } \\
\text { Deviation } \\
\text { (Mean) }\end{array}$ & $\begin{array}{l}\text { Projected } \\
\text { Inventory }\end{array}$ \\
\hline Metal & & $\mu \mathrm{g} / \mathrm{g}$ & $\mu \mathrm{g} / \mathrm{g}$ & $\mu \mathrm{g} / \mathrm{g}$ & $\mu \mathrm{g} / \mathrm{g}$ & $\mathrm{kg}$ \\
\hline \multirow[t]{2}{*}{ ICP.a.Zr } & Sample D25-8755 & 88.9 & \multirow{2}{*}{$\begin{array}{l}12.7 \\
\text { to } \\
88.9\end{array}$} & \multirow[t]{2}{*}{50.8} & \multirow[t]{2}{*}{38.1} & \multirow[t]{8}{*}{72.4} \\
\hline & Sample D33-8755 & $(12.7)$ & & & & \\
\hline \multirow{2}{*}{$\begin{array}{l}\text { Homgen. } \\
\text { Data }\end{array}$} & Sample D40-8755 & $(73.8)$ & \multirow{2}{*}{$\begin{array}{l}47.8 \\
\text { to } \\
73.8\end{array}$} & \multirow[t]{2}{*}{$\cdots$} & \multirow[t]{2}{*}{--} & \\
\hline & Sample D41-8755 & $(47.8)$ & & & & \\
\hline \multirow[t]{2}{*}{ ICP.w.Zr } & Sample D25-7755 & $(<0.719)$ & \multirow{2}{*}{$\begin{array}{c}<0.719 \\
\quad \text { to } \\
<6.16\end{array}$} & \multirow[t]{2}{*}{$<6.16$} & \multirow[t]{2}{*}{$N / A$} & \\
\hline & Sample D33-7755 & $(<6.16)$ & & & & \\
\hline \multirow[t]{2}{*}{ ICP.f.Zr } & Sample D25-6775 & $(146)$ & \multirow{2}{*}{$\begin{array}{c}91.6 \\
\text { to } \\
146\end{array}$} & \multirow[t]{2}{*}{119} & \multirow[t]{2}{*}{26.9} & \\
\hline & Sample D33-6755 & $(91.6)$ & & & & \\
\hline
\end{tabular}


Table A-2. Tank 241-T-105 Analytical Data: Ammonia

\begin{tabular}{||c|c|c|c|c|c|c|}
\hline Analyte & $\begin{array}{c}\text { Laboratory } \\
\text { Sample } \\
\text { Identification }\end{array}$ & $\begin{array}{c}\text { Analytical } \\
\text { Data } \\
\text { Result }\end{array}$ & $\begin{array}{c}\text { Range } \\
\text { of } \\
\text { Values }\end{array}$ & $\begin{array}{c}\text { Largest } \\
\text { Detection } \\
\text { Limit }\end{array}$ & $\begin{array}{c}\text { Standard } \\
\text { Deviation } \\
\text { (Mean) }\end{array}$ & $\begin{array}{c}\text { Projected } \\
\text { Inventory }\end{array}$ \\
\hline Cation & & $\mu \mathrm{g} / \mathrm{mL}$ & $\mu \mathrm{g} / \mathrm{mL}$ & $\mu \mathrm{g} / \mathrm{mL}$ & $\mu \mathrm{g} / \mathrm{mL}$ & $\mathrm{kg}$ \\
\hline $\begin{array}{r}\text { Dist/Tit. } \mathrm{NH}_{3} \\
\text { (Liquid) }\end{array}$ & Sample D19-5728 & $1<4001$ & $\mathrm{~N} / \mathrm{A}$ & $<400$ & $\mathrm{~N} / \mathrm{A}$ & $<148$ \\
\hline $\begin{array}{r}\text { Dist/Tit.NH/ } \\
\text { (Solid) }\end{array}$ & Sample D33-7728 & $1<20.01$ & $\mathrm{~N} / \mathrm{A}$ & $<20.0$ & $\mathrm{~N} / \mathrm{A}$ & \\
\hline
\end{tabular}

Table A-2. Tank 241-T-105 Analytical Data: Chloride

\begin{tabular}{|c|c|c|c|c|c|c|}
\hline Analyte & $\begin{array}{l}\text { Laboratory } \\
\text { Sample } \\
\text { Identification }\end{array}$ & $\begin{array}{c}\text { Analytical } \\
\text { Data } \\
\text { Result }\end{array}$ & $\begin{array}{c}\text { Range } \\
\text { of } \\
\text { Values }\end{array}$ & Mean & $\begin{array}{c}\text { Standard } \\
\text { Deviation } \\
\text { (Mean) }\end{array}$ & $\begin{array}{l}\text { Projected } \\
\text { Inventory }\end{array}$ \\
\hline Anion & & $\mu \mathrm{g} / \mathrm{mL}$ & $\mu \mathrm{g} / \mathrm{mL}$ & $\mu \mathrm{g} / \mathrm{mL}$ & $\mu \mathrm{g} / \mathrm{mL}$ & $\mathrm{kg}$ \\
\hline \multirow{2}{*}{$\begin{array}{l}\text { IC.Cl' } \\
\text { (Liquid) }\end{array}$} & Sample D19-5771 & $(229)$ & \multirow{2}{*}{$\begin{array}{l}8.80 \\
\text { to } \\
229 \\
\end{array}$} & \multirow{2}{*}{$\cdots$} & \multirow[t]{2}{*}{--} & \multirow[t]{4}{*}{149} \\
\hline & Sample D22-5771 & $(8.80)$ & & & & \\
\hline \multirow{2}{*}{$\begin{array}{l}\text { IC. } \mathrm{Cl}^{-} \\
\text {(Solid) }\end{array}$} & Sample D25-7771 & $(510)$ & \multirow{2}{*}{$\begin{array}{l}294 \\
\text { to } \\
510\end{array}$} & \multirow[t]{2}{*}{402} & \multirow[t]{2}{*}{109} & \\
\hline & Sample D33-7771 & $(294)$ & & & & \\
\hline
\end{tabular}

Table A-2. Tank 241-T-105 Analytical Data: Chromium (VI)

\begin{tabular}{||c|c|c|c|c|c|c||}
\hline Analyte & $\begin{array}{c}\text { Laboratory } \\
\text { Sample } \\
\text { Identification }\end{array}$ & $\begin{array}{c}\text { Analytical } \\
\text { Data } \\
\text { Result }\end{array}$ & $\begin{array}{c}\text { Range } \\
\text { of } \\
\text { Values }\end{array}$ & $\begin{array}{c}\text { Largest } \\
\text { Detection } \\
\text { Limit }\end{array}$ & $\begin{array}{c}\text { Standard } \\
\text { Deviation } \\
\text { (Mean) }\end{array}$ & $\begin{array}{c}\text { Projected } \\
\text { Inventory }\end{array}$ \\
\hline Cation & & $\mu \mathrm{g} / \mathrm{mL}$ & $\mu \mathrm{g} / \mathrm{mL}$ & $\mu \mathrm{g} / \mathrm{mL}$ & $\mu \mathrm{g} / \mathrm{mL}$ & $\mathrm{kg}$ \\
\hline $\begin{array}{r}\text { Spec.w. } \\
\mathrm{Cr}^{6+}\end{array}$ & Sample D25-7869 & $(<18.3)$ & $\mathrm{N} / \mathrm{A}$ & $<18.3$ & $\mathrm{~N} / \mathrm{A}$ & $<6.79$ \\
\cline { 2 - 8 } & Sample D33-7769 & $(<18.3)$ & & & \\
\hline
\end{tabular}


Table A-2. Tank 241-T-105 Analytical Data: Cyanide

\begin{tabular}{||c|c|c|c|c|c|c||}
\hline Analyte & $\begin{array}{c}\text { Laboratory } \\
\text { Sample } \\
\text { Identification }\end{array}$ & $\begin{array}{c}\text { Analytical } \\
\text { Data } \\
\text { Result }\end{array}$ & $\begin{array}{c}\text { Range } \\
\text { of } \\
\text { Values }\end{array}$ & Mean & $\begin{array}{c}\text { Standard } \\
\text { Deviation } \\
\text { (Mean) }\end{array}$ & $\begin{array}{c}\text { Projected } \\
\text { Inventory }\end{array}$ \\
\hline Anion & & $\mu \mathrm{g} / \mathrm{g}$ & $\mu \mathrm{g} / \mathrm{g}$ & $\mu \mathrm{g} / \mathrm{g}$ & $\mu \mathrm{g} / \mathrm{g}$ & $\mathrm{kg}$ \\
\hline $\begin{array}{r}\text { Dist/Spec. } \\
\mathrm{CN}^{*}\end{array}$ & Sample D25-5777 & 16.5 & \begin{tabular}{c}
6.26 \\
to \\
\cline { 2 - 7 }
\end{tabular} & Sample D33-5777 & $(6.26)$ & 16.5
\end{tabular}

Table A-2. Tank 241-T-105 Analytical Data: Fluoride

\begin{tabular}{|c|c|c|c|c|c|c|}
\hline Analyte & $\begin{array}{l}\text { Laboratory } \\
\text { Sample } \\
\text { Identification }\end{array}$ & $\begin{array}{c}\text { Analytical } \\
\text { Data } \\
\text { Result }\end{array}$ & $\begin{array}{c}\text { Range } \\
\text { of } \\
\text { Values }\end{array}$ & $\begin{array}{l}\text { Largest } \\
\text { Detection } \\
\text { Limit }\end{array}$ & $\begin{array}{c}\text { Standard } \\
\text { Deviation } \\
\text { (Mean) }\end{array}$ & $\begin{array}{l}\text { Projected } \\
\text { Inventory }\end{array}$ \\
\hline Anion & & $\mu \mathrm{g} / \mathrm{mL}$ & $\mu \mathrm{g} / \mathrm{mL}$ & $\mu \mathrm{g} / \mathrm{mL}$ & $\mu \mathrm{g} / \mathrm{mL}$ & $\mathrm{kg}$ \\
\hline \multirow[t]{2}{*}{ IC.F } & Sample D19-5771 & $1<10.1)$ & \multirow{2}{*}{$\begin{array}{c}1.26 \\
\text { to } \\
<10.1\end{array}$} & \multirow[t]{2}{*}{1.26} & \multirow[t]{2}{*}{ N/A } & \multirow[t]{2}{*}{0.467} \\
\hline & Sample D22-5771 & $(1.26)$ & & & & \\
\hline
\end{tabular}

Table A-2. Tank 241-T-105 Analytical Data: Hydroxide

\begin{tabular}{|c|c|c|c|c|c|c|}
\hline $\begin{array}{c}\text { Analyte } \\
.\end{array}$ & $\begin{array}{l}\text { Laboratory } \\
\text { Sample } \\
\text { Identification }\end{array}$ & $\begin{array}{c}\text { Analytical } \\
\text { Data } \\
\text { Result }\end{array}$ & $\begin{array}{c}\text { Range } \\
\text { of } \\
\text { Values }\end{array}$ & $\begin{array}{c}\text { Largest } \\
\text { Detection } \\
\text { Limit }\end{array}$ & $\begin{array}{c}\text { Standard } \\
\text { Deviation } \\
\text { (Mean) }\end{array}$ & $\begin{array}{l}\text { Projected } \\
\text { Inventory }\end{array}$ \\
\hline $\begin{array}{l}\text { Anion } \\
\text { (Liquid) }\end{array}$ & & $\mu \mathrm{g} / \mathrm{mL}$ & $\mu \mathrm{g} / \mathrm{mL}$ & $\mu \mathrm{g} / \mathrm{mL}$ & $\mu \mathrm{g} / \mathrm{mL}$ & $\mathrm{kg}$ \\
\hline ITS.OH & Sample D33-5724 & $(<1,250)$ & N/A & $<1,250$ & N/A & \multirow[t]{3}{*}{$<760$} \\
\hline $\begin{array}{l}\text { Anion } \\
\text { (Solid) }\end{array}$ & & $\mu \mathrm{g} / \mathrm{g}$ & $\mu \mathrm{g} / \mathrm{g}$ & $\mu \mathrm{g} / \mathrm{g}$ & $\mu \mathrm{g} / \mathrm{g}$ & \\
\hline ITS.OH' & Sample D25-5724 & $(<1,250)$ & $N / A$ & $<1,250$ & $N / A$ & \\
\hline
\end{tabular}


Table A-2. Tank 241-T-105 Analytical Data: Nitrate

\begin{tabular}{|c|c|c|c|c|c|c|}
\hline Analyte & $\begin{array}{c}\text { Laboratory } \\
\text { Sample } \\
\text { Identification }\end{array}$ & $\begin{array}{c}\text { Analytical } \\
\text { Data } \\
\text { Result }\end{array}$ & $\begin{array}{c}\text { Range } \\
\text { of } \\
\text { Values }\end{array}$ & Mean & $\begin{array}{c}\text { Standard } \\
\text { Deviation } \\
\text { (Mean) }\end{array}$ & $\begin{array}{l}\text { Projected } \\
\text { Inventory }\end{array}$ \\
\hline Anion & & $\mu \mathrm{g} / \mathrm{mL}$ & $\mu \mathrm{g} / \mathrm{mL}$ & $\mu \mathrm{g} / \mathrm{mL}$ & $\mu \mathrm{g} / \mathrm{mL}$ & $\mathrm{kg}$ \\
\hline \multirow{2}{*}{$\begin{array}{l}\text { IC. } \mathrm{NO}_{3}^{-} \\
\text {(Liquid) }\end{array}$} & Sample D19-5771 & $(8,120)$ & \multirow{2}{*}{$\begin{array}{c}5.56 \\
\text { to } \\
8,120\end{array}$} & \multirow[t]{2}{*}{--} & \multirow[t]{2}{*}{$\cdots$} & \multirow[t]{4}{*}{7,870} \\
\hline & Sample D22-5771 & $(5.56)$ & & & & \\
\hline \multirow{2}{*}{$\begin{array}{r}\text { IC. } \mathrm{NO}_{3}^{-} \\
\text {(Segment) }\end{array}$} & Sample D25-7771 & $(26,900)$ & \multirow{2}{*}{$\begin{array}{c}15,500 \\
\text { to } \\
26,900\end{array}$} & \multirow[t]{2}{*}{21,200} & \multirow[t]{2}{*}{5,700} & \\
\hline & Sample D33-7771 & $(15,500)$ & & & & \\
\hline
\end{tabular}

Table A-2. Tank 241-T-105 Analytical Data: Nitrite

\begin{tabular}{|c|c|c|c|c|c|c|}
\hline Analyte & $\begin{array}{l}\text { Laboratory } \\
\text { Sample } \\
\text { Identification }\end{array}$ & $\begin{array}{c}\text { Analytical } \\
\text { Data } \\
\text { Result }\end{array}$ & $\begin{array}{c}\text { Range } \\
\text { of } \\
\text { Values }\end{array}$ & Mean & $\begin{array}{l}\text { Standard } \\
\text { Deviation } \\
\text { (Mean) }\end{array}$ & $\begin{array}{l}\text { Projected } \\
\text { Inventory }\end{array}$ \\
\hline $\begin{array}{l}\text { Anion } \\
\text { (Liquid) }\end{array}$ & & $\mu \mathrm{g} / \mathrm{mL}$ & $\mu \mathrm{g} / \mathrm{mL}$ & $\mu \mathrm{g} / \mathrm{mL}$ & $\mu \mathrm{g} / \mathrm{mL}$ & $\mathrm{kg}$ \\
\hline \multirow[t]{3}{*}{ IC.d. $\mathrm{NO}_{2}^{-}$} & Sample D19-5771 & $(11,700)$ & \multirow{3}{*}{$\begin{array}{c}49.0 \\
\text { to } \\
17,500\end{array}$} & \multirow[t]{3}{*}{9,750} & \multirow[t]{3}{*}{ N/A } & \multirow[t]{8}{*}{11,100} \\
\hline & Sample D19-5779 & $(17,500)$ & & & & \\
\hline & Sample D22-5771 & $(49.0)$ & & & & \\
\hline \multirow[t]{3}{*}{ IC.w. $\mathrm{NO}_{2}^{-}$} & Sample D25-7771 & $(37,800)$ & \multirow{3}{*}{$\begin{array}{c}713 \\
\text { to } \\
37,800\end{array}$} & \multirow[t]{3}{*}{29,800} & \multirow[t]{3}{*}{8,020} & \\
\hline & Sample D33-7779 & $(713)$ & & & & \\
\hline & Sample D33-7771 & $(21,800)$ & & & & \\
\hline $\begin{array}{l}\text { Anion } \\
\text { (Solid) }\end{array}$ & & $\mu \mathrm{g} / \mathrm{g}$ & $\mu \mathrm{g} / \mathrm{g}$ & $\mu \mathrm{g} / \mathrm{g}$ & $\mu \mathrm{g} / \mathrm{g}$ & \\
\hline IC.W. $\mathrm{NO}_{2}^{-}$ & Sample D25-7779 & $(276)$ & N/A & 276 & N/A & \\
\hline
\end{tabular}


Table A-2. Tank 241-T-105 Analytical Data: Phosphate

\begin{tabular}{|c|c|c|c|c|c|c|}
\hline Analyte & $\begin{array}{l}\text { Laboratory } \\
\text { Sample } \\
\text { Identification }\end{array}$ & $\begin{array}{c}\text { Analytical } \\
\text { Data } \\
\text { Result }\end{array}$ & $\begin{array}{c}\text { Range } \\
\text { of } \\
\text { Values }\end{array}$ & Mean & $\begin{array}{c}\text { Standard } \\
\text { Deviation } \\
\text { (Mean) }\end{array}$ & $\begin{array}{l}\text { Projected } \\
\text { Inventory }\end{array}$ \\
\hline Anion & & $\mu \mathrm{g} / \mathrm{mL}$ & $\mu \mathrm{g} / \mathrm{mL}$ & $\mu \mathrm{g} / \mathrm{mL}$ & $\mu \mathrm{g} / \mathrm{mL}$ & $\mathrm{kg}$ \\
\hline \multirow[t]{2}{*}{ IC.d. $\mathrm{PO}_{4}{ }^{3-}$} & Sample D19-5771 & $(1,580)$ & \multirow{2}{*}{$\begin{array}{c}<1.00 \\
\text { to } \\
1,580\end{array}$} & \multirow[t]{2}{*}{1,580} & \multirow[t]{2}{*}{ N/A } & \multirow[t]{4}{*}{81.2} \\
\hline & Sample D22-5771 & $1<1.00)$ & & & & \\
\hline \multirow[t]{2}{*}{ IC. W. $\mathrm{PO}_{4}{ }^{3-}$} & Sample D25-7771 & $(2,610)$ & \multirow{2}{*}{$\begin{array}{c}1,760 \\
\text { to } \\
2,610\end{array}$} & \multirow[t]{2}{*}{2,190} & \multirow[t]{2}{*}{423} & \\
\hline & Sample D33-7771 & $(1,760)$ & & & & \\
\hline
\end{tabular}

Table A-2. Tank 241-T-105 Analytical Data: Sulfate

\begin{tabular}{|c|c|c|c|c|c|c|}
\hline Analyte & $\begin{array}{l}\text { Laboratory } \\
\text { Sample } \\
\text { Identification }\end{array}$ & $\begin{array}{c}\text { Analytical } \\
\text { Data } \\
\text { Result }\end{array}$ & $\begin{array}{c}\text { Range } \\
\text { of } \\
\text { Values }\end{array}$ & Mean & $\begin{array}{c}\text { Standard } \\
\text { Deviation } \\
\text { (Mean) }\end{array}$ & $\begin{array}{l}\text { Projected } \\
\text { Inventory }\end{array}$ \\
\hline Anion & & $\mu \mathrm{g} / \mathrm{mL}$ & $\mu \mathrm{g} / \mathrm{mL}$ & $\mu \mathrm{g} / \mathrm{mL}$ & $\mu \mathrm{g} / \mathrm{mL}$ & $\mathrm{kg}$ \\
\hline \multirow[t]{2}{*}{ IC.d. $\mathrm{SO}_{4}{ }^{2-}$} & Sample D19-5771 & $(3,490)$ & \multirow{2}{*}{$\begin{array}{c}41.8 \\
\text { to } \\
3,490\end{array}$} & \multirow[t]{2}{*}{1,770} & \multirow[t]{2}{*}{ N/A } & \multirow[t]{4}{*}{3,170} \\
\hline & Sample D22-5771 & $(41.8)$ & & & & \\
\hline \multirow[t]{2}{*}{ IC. $\mathrm{w}^{-\mathrm{SO}_{4}{ }^{2-}}$} & Sample D25-7771 & $(10,800)$ & \multirow{2}{*}{$\begin{array}{c}6,250 \\
\text { to } \\
10,800\end{array}$} & \multirow[t]{2}{*}{8,550} & \multirow[t]{2}{*}{2,300} & \\
\hline & Sample D33-7771 & $(6.250)$ & & & & \\
\hline
\end{tabular}


Table A-3. Tank 241-T-105 Analytical Data: Americium-241 *

\begin{tabular}{|c|c|c|c|c|c|c|}
\hline Analyte & $\begin{array}{l}\text { Laboratory } \\
\text { Sample } \\
\text { Identification }\end{array}$ & $\begin{array}{c}\text { Analytical } \\
\text { Data } \\
\text { Result }\end{array}$ & $\begin{array}{c}\text { Range } \\
\text { of } \\
\text { Values }\end{array}$ & Mean & $\begin{array}{l}\text { Standard } \\
\text { Deviation } \\
\text { (Mean) }\end{array}$ & $\begin{array}{l}\text { Projected } \\
\text { Inventory }\end{array}$ \\
\hline Radionuclide & & $\mu \mathrm{Ci} / \mathrm{g}$ & $\mu \mathrm{Ci} / \mathrm{g}$ & $\mu \mathrm{Ci} / \mathrm{g}$ & $\mu \mathrm{Ci} / \mathrm{g}$ & $\mathrm{Ci}$ \\
\hline \multirow[t]{2}{*}{ GEA.f. ${ }^{241} \mathrm{Am}$} & Sample D33-6730 & $<0.134$ & \multirow{2}{*}{$\begin{array}{l}<0.134 \\
\text { to } \\
<0.770\end{array}$} & \multirow[t]{2}{*}{$<0.770$} & \multirow[t]{2}{*}{ N/A } & \multirow[t]{6}{*}{521} \\
\hline & Sample D25-6730 & $<0.770$ & & & & \\
\hline \multirow[t]{2}{*}{ GEA.W. $\cdot{ }^{241} \mathrm{Am}$} & Sample D25-7730 & $<0.164$ & \multirow{2}{*}{$\begin{array}{c}<0.130 \\
\text { to } \\
<0.164 \\
\end{array}$} & \multirow[t]{2}{*}{$<0.164$} & \multirow[t]{2}{*}{ N/A } & \\
\hline & Sample D33-7730 & $<0.130$ & & & & \\
\hline \multirow{2}{*}{$\begin{array}{l}\text { GEA.RS. } \\
{ }^{241} \mathrm{Am}\end{array}$} & Sample D37-9730 & $(0.245)$ & \multirow{2}{*}{$\begin{array}{c}0.245 \\
\text { to } \\
1.47 \\
\end{array}$} & \multirow[t]{2}{*}{0.857} & \multirow[t]{2}{*}{0.612} & \\
\hline & Sample D28-9730 & $(1.47)$ & & & & \\
\hline
\end{tabular}

Table A-3. Tank 241-T-105 Analytical Data: Americium-241

\begin{tabular}{|c|c|c|c|c|c|c|}
\hline Analyte & $\begin{array}{l}\text { Laboratory } \\
\text { Sample } \\
\text { Identification }\end{array}$ & $\begin{array}{c}\text { Analytical } \\
\text { Data } \\
\text { Result }\end{array}$ & $\begin{array}{c}\text { Range } \\
\text { of } \\
\text { Values }\end{array}$ & $\begin{array}{c}\text { Largest } \\
\text { Detection } \\
\text { Limit } \\
\end{array}$ & $\begin{array}{c}\text { Standard } \\
\text { Deviation } \\
\text { (Mean) }\end{array}$ & $\begin{array}{l}\text { Projected } \\
\text { Inventory }\end{array}$ \\
\hline $\begin{array}{l}\text { Radionuclide } \\
\text { (Liquid) }\end{array}$ & & $\mu \mathrm{Ci} / \mathrm{mL}$ & $\mu \mathrm{Ci} / \mathrm{mL}$ & $\mu \mathrm{Ci} / \mathrm{mL}$ & $\mu \mathrm{Ci} / \mathrm{mL}$ & $\mathrm{Ci}$ \\
\hline $\begin{array}{l}\text { Alpha Spec.d. } \\
{ }^{241} \mathrm{Am}\end{array}$ & Sample D19-5782 & (8.28E-05) & N/A & $8.28 E-05$ & N/A & 240 \\
\hline $\begin{array}{l}\text { Radionuclide } \\
\text { (Solid) }\end{array}$ & & $\mu \mathrm{Ci} / \mathrm{g}$ & $\mu \mathrm{Ci} / \mathrm{g}$ & $\mu \mathrm{Ci} / \mathrm{g}$ & $\mu \mathrm{Ci} / \mathrm{g}$ & \\
\hline \multirow{2}{*}{$\begin{array}{r}\text { Alpha Spec.f. } \\
{ }^{241} \mathrm{Am}\end{array}$} & Sample D25-6782 & $(0.395)$ & \multirow[t]{2}{*}{ N/A } & \multirow[t]{2}{*}{0.395} & \multirow[t]{2}{*}{ N/A } & \\
\hline & Sample D33-6782 & 0.0888 & & & & \\
\hline
\end{tabular}


Table A-3. Tank 241-T-105 Analytical Data: Antimony-125

\begin{tabular}{|r|c|c|c|c|c|c||}
\hline Analyte & $\begin{array}{c}\text { Laboratory } \\
\text { Sample } \\
\text { Identification }\end{array}$ & $\begin{array}{c}\text { Analytical } \\
\text { Data } \\
\text { Result }\end{array}$ & $\begin{array}{c}\text { Range } \\
\text { of } \\
\text { Values }\end{array}$ & Mean & $\begin{array}{c}\text { Standard } \\
\text { Deviation } \\
\text { (Mean) }\end{array}$ & $\begin{array}{c}\text { Projected } \\
\text { Inventory }\end{array}$ \\
\hline Radionuclide & & $\mu \mathrm{Ci} / \mathrm{g}$ & $\mu \mathrm{Ci} / \mathrm{g}$ & $\mu \mathrm{Ci} / \mathrm{g}$ & $\mu \mathrm{Ci} / \mathrm{g}$ & $\mathrm{Ci}$ \\
\hline $\begin{array}{r}\text { GEA.RS. } \\
125 \mathrm{Sb}\end{array}$ & Sample D28-9730 & 0.665 & $\mathrm{~N} / \mathrm{A}$ & 0.665 & $\mathrm{~N} / \mathrm{A}$ & 404 \\
\hline
\end{tabular}

Table A-3. Tank 241-T-105 Analytical Data: Carbon-14

\begin{tabular}{||c|c|c|c|c|c|c|}
\hline Analyte & $\begin{array}{c}\text { Laboratory } \\
\text { Sample } \\
\text { Identification }\end{array}$ & $\begin{array}{c}\text { Analytical } \\
\text { Data } \\
\text { Result }\end{array}$ & $\begin{array}{c}\text { Range } \\
\text { of } \\
\text { Values }\end{array}$ & Mean & $\begin{array}{c}\text { Standard } \\
\text { Deviation } \\
\text { (Mean) }\end{array}$ & $\begin{array}{c}\text { Projected } \\
\text { Inventory }\end{array}$ \\
\hline $\begin{array}{l}\text { Radionuclide } \\
\text { (Liquid) }\end{array}$ & & $\mu \mathrm{Ci} / \mathrm{mL}$ & $\mu \mathrm{Ci} / \mathrm{mL}$ & $\mu \mathrm{Ci} / \mathrm{mL}$ & $\mu \mathrm{Ci} / \mathrm{mL}$ & $\mathrm{Ci}$ \\
\hline LSC.d. ${ }^{14} \mathrm{C}$ & Sample D37-7788 & $6.84 \mathrm{E}-04$ & $\mathrm{~N} / \mathrm{A}$ & $6.84 \mathrm{E}-04$ & $\mathrm{~N} / \mathrm{A}$ & 0.809 \\
\hline $\begin{array}{l}\text { Radionuclide } \\
\text { (Solid) }\end{array}$ & & $\mu \mathrm{Ci} / \mathrm{g}$ & $\mu \mathrm{Ci} / \mathrm{g}$ & $\mu \mathrm{Ci} / \mathrm{g}$ & $\mu \mathrm{Ci} / \mathrm{g}$ & \\
\hline LSC.w. ${ }^{14} \mathrm{C}$ & Sample D27-7788 & $10.00133)$ & N/A & 0.00133 & N/A \\
\hline
\end{tabular}

Table A-3. Tank 241-T-105 Analytical Data: Cerium/Praseodymium-144

\begin{tabular}{|c|c|c|c|c|c|c|}
\hline Analyte & $\begin{array}{l}\text { Laboratory } \\
\text { Sample } \\
\text { Identification }\end{array}$ & $\begin{array}{c}\text { Analytical } \\
\text { Data } \\
\text { Result }\end{array}$ & $\begin{array}{c}\text { Range } \\
\text { of } \\
\text { Values }\end{array}$ & $\begin{array}{c}\text { Largest } \\
\text { Detection } \\
\text { Limit }\end{array}$ & $\begin{array}{c}\text { Standard } \\
\text { Deviation } \\
\text { (Mean) }\end{array}$ & $\begin{array}{l}\text { Projected } \\
\text { Inventory }\end{array}$ \\
\hline Radionuclide & & $\mu \mathrm{Ci} / \mathrm{g}$ & $\mu \mathrm{Ci} / \mathrm{g}$ & $\mu \mathrm{Ci} / \mathrm{g}$ & $\mu \mathrm{Ci} / \mathrm{g}$ & $\mathrm{Ci}$ \\
\hline \multirow{2}{*}{$\begin{array}{l}\text { GEA.f. } \\
{ }^{144} \mathrm{CePr}\end{array}$} & Sample D33-6730 & $<0.187$ & \multirow{2}{*}{$\begin{array}{c}<0.187 \\
\text { to } \\
<1.74\end{array}$} & \multirow[t]{2}{*}{$<1.74$} & \multirow[t]{2}{*}{ N/A } & \multirow[t]{6}{*}{$<1,060$} \\
\hline & Sample D25-6730 & $<1.74$ & & & & \\
\hline \multirow{2}{*}{$\begin{array}{l}\text { GEA.w. } \\
{ }^{144} \mathrm{CePr}\end{array}$} & Sample D25-7730 & $<0.245$ & \multirow{2}{*}{$\begin{array}{c}<0.194 \\
\text { to } \\
<0.245\end{array}$} & \multirow[t]{2}{*}{$<0.245$} & \multirow[t]{2}{*}{ N/A } & \\
\hline & Sample D33-7730 & $<0.194$ & & & & \\
\hline \multirow{2}{*}{$\begin{array}{l}\text { GEA.RS } \\
{ }^{144} \mathrm{CePr}\end{array}$} & Sample D37-9730 & $<0.342$ & \multirow{2}{*}{$\begin{array}{l}<0.342 \\
\quad \text { to } \\
<0.674\end{array}$} & \multirow[t]{2}{*}{$<0.674$} & \multirow[t]{2}{*}{ N/A } & \\
\hline & Sample D28-9730 & $<0.674$ & & & & \\
\hline
\end{tabular}


Table A-3. Tank 241-T-105 Analytical Data: Cesium-134

\begin{tabular}{|c|c|c|c|c|c|c|}
\hline Analyte & $\begin{array}{l}\text { Laboratory } \\
\text { Sample } \\
\text { Identification }\end{array}$ & $\begin{array}{c}\text { Analytical } \\
\text { Data } \\
\text { Resuit }\end{array}$ & $\begin{array}{c}\text { Range } \\
\text { of } \\
\text { Values }\end{array}$ & $\begin{array}{c}\text { Largest } \\
\text { Detection } \\
\text { Limit }\end{array}$ & $\begin{array}{c}\text { Standard } \\
\text { Deviation } \\
\text { (Mean) }\end{array}$ & $\begin{array}{l}\text { Projected } \\
\text { Inventory }\end{array}$ \\
\hline Radionuclide & & $\mu \mathrm{Ci} / \mathrm{g}$ & $\mu \mathrm{Ci} / \mathrm{g}$ & $\mu \mathrm{Ci} / \mathrm{g}$ & $\mu \mathrm{Ci} / \mathrm{g}$ & $\mathrm{Ci}$ \\
\hline \multirow[t]{2}{*}{ GEA.f. ${ }^{134} \mathrm{Cs}$} & Sample D33-6730 & $<0.00757$ & \multirow{2}{*}{$\begin{array}{c}<0.00757 \\
\text { to } \\
<0.106\end{array}$} & \multirow[t]{2}{*}{$<0.106$} & \multirow[t]{2}{*}{ N/A } & \multirow[t]{6}{*}{$<64.4$} \\
\hline & Sample D25-6730 & $<0.106$ & & & & \\
\hline \multirow[t]{2}{*}{ GEA.w. ${ }^{134} \mathrm{Cs}$} & Sample D25-7730 & $<0.0126$ & \multirow{2}{*}{$\begin{array}{c}<0.0120 \\
\text { to } \\
<0.0126\end{array}$} & \multirow[t]{2}{*}{$<0.0126$} & \multirow[t]{2}{*}{ N/A } & \\
\hline & Sample D33-7730 & $<0.0120$ & & & & \\
\hline \multirow{2}{*}{$\begin{array}{r}\text { GEA.RS. } \\
{ }^{134} \mathrm{Cs}\end{array}$} & Sample D37-9730 & $<0.0116$ & \multirow{2}{*}{$\begin{array}{c}<0.0116 \\
\text { to } \\
<0.0320\end{array}$} & \multirow[t]{2}{*}{$<0.0320$} & \multirow[t]{2}{*}{ N/A } & \\
\hline & Sample D28-9730 & $<0.0320$ & & & & \\
\hline
\end{tabular}

Table A-3. Tank 241-T-105 Analytical Data: Cesium-137

\begin{tabular}{|c|c|c|c|c|c|c|}
\hline Analyte & $\begin{array}{l}\text { Laboratory } \\
\text { Sample } \\
\text { Identification }\end{array}$ & $\begin{array}{c}\text { Analytical } \\
\text { Data } \\
\text { Result }\end{array}$ & $\begin{array}{c}\text { Range } \\
\text { of } \\
\text { Values }\end{array}$ & Mean & $\begin{array}{c}\text { Standard } \\
\text { Deviation } \\
\text { (Mean) }\end{array}$ & $\begin{array}{l}\text { Projected } \\
\text { Inventory }\end{array}$ \\
\hline Radionuclide & & $\mu \mathrm{Ci} / \mathrm{g}$ & $\mu \mathrm{Ci} / \mathrm{g}$ & $\mu \mathrm{Ci} / \mathrm{g}$ & $\mu \mathrm{Ci} / \mathrm{g}$ & $\mathrm{Ci}$ \\
\hline \multirow[t]{2}{*}{ GEA.f. ${ }^{137} \mathrm{Cs}$} & Sample D33-6730 & 36.6 & \multirow{2}{*}{$\begin{array}{c}36.6 \\
\text { to } \\
61.8\end{array}$} & \multirow[t]{2}{*}{49.2} & \multirow[t]{2}{*}{ N/A } & \multirow[t]{6}{*}{33,800} \\
\hline & Sample D25-6730 & 61.8 & & & & \\
\hline \multirow[t]{2}{*}{ GEA.w. ${ }^{137} \mathrm{Cs}$} & Sample D25-7730 & 40.8 & \multirow{2}{*}{$\begin{array}{l}23.9 \\
\text { to } \\
40.8\end{array}$} & \multirow[t]{2}{*}{32.3} & \multirow[t]{2}{*}{8.45} & \\
\hline & Sample D33-7730 & 23.9 & & & & \\
\hline \multirow{2}{*}{$\begin{array}{r}\text { GEA.RS. } \\
{ }^{137} \mathrm{Cs}\end{array}$} & Sample D37-9730 & $(45.5)$ & \multirow{2}{*}{$\begin{array}{c}45.5 \\
\text { to } \\
65.6\end{array}$} & \multirow[t]{2}{*}{55.6} & \multirow[t]{2}{*}{ N/A } & \\
\hline & Sample D28-9730 & $(65.6)$ & & & & \\
\hline
\end{tabular}


Table A-3. Tank 241-T-105 Analytical Data: Cobalt-60

\begin{tabular}{|c|c|c|c|c|c|c|}
\hline Analyte & $\begin{array}{l}\text { Laboratory } \\
\text { Sample } \\
\text { Identification }\end{array}$ & $\begin{array}{c}\text { Analytical } \\
\text { Data } \\
\text { Result }\end{array}$ & $\begin{array}{c}\text { Range } \\
\text { of } \\
\text { Values }\end{array}$ & Mean & $\begin{array}{c}\text { Standard } \\
\text { Deviation } \\
\text { (Mean) }\end{array}$ & $\begin{array}{l}\text { Projected } \\
\text { Inventory }\end{array}$ \\
\hline Radionuclide & & $\mu \mathrm{Ci} / \mathrm{g}$ & $\mu \mathrm{Ci} / \mathrm{g}$ & $\mu \mathrm{Ci} / \mathrm{g}$ & $\mu \mathrm{Ci} / \mathrm{g}$ & $\mathrm{Ci}$ \\
\hline \multirow[t]{2}{*}{ GEA.f. ${ }^{60} \mathrm{Co}$} & Sample D33-6730 & 0.0195 & \multirow{2}{*}{$\begin{array}{c}0.0195 \\
\text { to } \\
<0.0913\end{array}$} & \multirow[t]{2}{*}{0.0195} & \multirow[t]{2}{*}{ N/A } & \multirow[t]{6}{*}{1,280} \\
\hline & Sample D25-6730 & $<0.0913$ & & & & \\
\hline \multirow[t]{2}{*}{ GEA. $w .{ }^{60} \mathrm{Co}$} & Sample D25-7730 & $<0.0136$ & \multirow{2}{*}{$\begin{array}{c}<0.0119 \\
\text { to } \\
<0.0136\end{array}$} & \multirow[t]{2}{*}{$<0.0136$} & \multirow[t]{2}{*}{ N/A } & \\
\hline & Sample D33-7730 & $<0.0119$ & & & & \\
\hline \multirow[t]{2}{*}{ GEA.RS ${ }^{60} \mathrm{Co}$} & Sample D37-9730 & $(0.623)$ & \multirow{2}{*}{$\begin{array}{c}0.623 \\
\text { to } \\
3.60\end{array}$} & \multirow[t]{2}{*}{2.11} & \multirow[t]{2}{*}{ N/A } & \\
\hline & Sample D28-9730 & $(3.60)$ & & & & \\
\hline
\end{tabular}

Table A-3. Tank 241-T-105 Analytical Data: Europium-154

\begin{tabular}{|c|c|c|c|c|c|c|}
\hline Analyte & $\begin{array}{l}\text { Laboratory } \\
\text { Sample } \\
\text { Identification }\end{array}$ & $\begin{array}{c}\text { Analytical } \\
\text { Data } \\
\text { Result }\end{array}$ & $\begin{array}{c}\text { Range } \\
\text { of } \\
\text { Values }\end{array}$ & Mean & $\begin{array}{c}\text { Standard } \\
\text { Deviation } \\
\text { (Mean) }\end{array}$ & $\begin{array}{l}\text { Projected } \\
\text { Inventory }\end{array}$ \\
\hline Radionuclide & & $\mu \mathrm{Ci} / \mathrm{g}$ & $\mu \mathrm{Ci} / \mathrm{g}$ & $\mu \mathrm{Ci} / \mathrm{g}$ & $\mu \mathrm{Ci} / \mathrm{g}$ & $\mathrm{Ci}$ \\
\hline \multirow[t]{2}{*}{ GEA.f. ${ }^{154} \mathrm{Eu}$} & Sample D33-6730 & 0.233 & \multirow{2}{*}{$\begin{array}{c}0.233 \\
\text { to } \\
1.24\end{array}$} & \multirow[t]{2}{*}{0.737} & \multirow[t]{2}{*}{ N/A } & \multirow[t]{6}{*}{448} \\
\hline & Sample D25-6730 & $(1.24)$ & & & & \\
\hline \multirow[t]{2}{*}{ GEA.w. ${ }^{154} \mathrm{Eu}$} & Sample D25-7730 & $<0.0372$ & \multirow{2}{*}{$\begin{array}{c}<0.0372 \\
\text { to } \\
<0.0418 \\
\end{array}$} & \multirow[t]{2}{*}{$<0.0418$} & \multirow[t]{2}{*}{ N/A } & \\
\hline & Sample D33-7730 & $<0.0418$ & & & & \\
\hline \multirow{2}{*}{$\begin{array}{r}\text { GEA.RS. } \\
{ }^{154} \mathrm{Eu}\end{array}$} & Sample D37-9730 & $(0.0234)$ & \multirow{2}{*}{$\begin{array}{c}0.0234 \\
\text { to } \\
0.0532\end{array}$} & \multirow[t]{2}{*}{0.0383} & \multirow[t]{2}{*}{ N/A } & \\
\hline & Sample D28-9730 & $(0.0532)$ & & & & \\
\hline
\end{tabular}


Table A-3. Tank 241-T-105 Analytical Data: Europium-155

\begin{tabular}{|c|c|c|c|c|c|c|}
\hline Analyte & $\begin{array}{l}\text { Laboratory } \\
\text { Sample } \\
\text { Identification }\end{array}$ & $\begin{array}{c}\text { Analytical } \\
\text { Data } \\
\text { Result }\end{array}$ & $\begin{array}{c}\text { Range } \\
\text { of } \\
\text { Values }\end{array}$ & Mean & $\begin{array}{c}\text { Standard } \\
\text { Deviation } \\
\text { (Mean) }\end{array}$ & $\begin{array}{l}\text { Projected } \\
\text { Inventory }\end{array}$ \\
\hline Radionuclide & & $\mu \mathrm{Ci} / \mathrm{g}$ & $\mu \mathrm{Ci} / \mathrm{g}$ & $\mu \mathrm{Ci} / \mathrm{g}$ & $\mu \mathrm{Ci} / \mathrm{g}$ & $\mathrm{Ci}$ \\
\hline \multirow[t]{2}{*}{ GEA.f. ${ }^{155} \mathrm{Eu}$} & Sample D33-6730 & 0.206 & \multirow{2}{*}{$\begin{array}{c}0.206 \\
\text { to } \\
1.19\end{array}$} & \multirow[t]{2}{*}{0.698} & \multirow[t]{2}{*}{ N/A } & \multirow[t]{6}{*}{1,280} \\
\hline & Sample D25-6730 & $(1.19)$ & & & & \\
\hline \multirow[t]{2}{*}{ GEA.w. ${ }^{155} \mathrm{Eu}$} & Sample D25-7730 & $<0.0748$ & \multirow{2}{*}{$\begin{array}{c}<0.0592 \\
\text { to } \\
<0.0748\end{array}$} & \multirow[t]{2}{*}{$<0.0748$} & \multirow[t]{2}{*}{ N/A } & \\
\hline & Sample D33-7730 & $<0.0592$ & & & & \\
\hline \multirow{2}{*}{$\begin{array}{r}\text { GEA.RS. } \\
{ }^{155} \mathrm{Eu}\end{array}$} & Sample D37-9730 & $(0.574)$ & \multirow{2}{*}{$\begin{array}{l}0.574 \\
-\quad \text { to } \\
3.00\end{array}$} & \multirow[t]{2}{*}{2.11} & \multirow[t]{2}{*}{1.49} & \\
\hline & Sample D28-9730 & $(3.00)$ & & & & \\
\hline
\end{tabular}

Table A-3. Tank 241-T-105 Analytical Data: Potassium-40

\begin{tabular}{|c|c|c|c|c|c|c|}
\hline Analyte & $\begin{array}{l}\text { Laboratory } \\
\text { Sample } \\
\text { Identification }\end{array}$ & $\begin{array}{c}\text { Analytical } \\
\text { Data } \\
\text { Result }\end{array}$ & $\begin{array}{c}\text { Range } \\
\text { of } \\
\text { Values }\end{array}$ & Mean & $\begin{array}{c}\text { Standard } \\
\text { Deviation } \\
\text { (Mean) }\end{array}$ & $\begin{array}{l}\text { Projected } \\
\text { Inventory }\end{array}$ \\
\hline Radionuclide & & $\mu \mathrm{Ci} / \mathrm{g}$ & $\mu \mathrm{Ci} / \mathrm{g}$ & $\mu \mathrm{Ci} / \mathrm{g}$ & $\mu \mathrm{Ci} / \mathrm{g}$ & $\mathrm{Ci}$ \\
\hline \multirow[t]{2}{*}{ GEA.f. ${ }^{40} \mathrm{~K}$} & Sample D33-6730 & $<0.152$ & \multirow{2}{*}{$\begin{array}{c}<0.152 \\
\text { to } \\
<2.95\end{array}$} & \multirow[t]{2}{*}{$<2.95$} & \multirow[t]{2}{*}{ N/A } & \multirow[t]{6}{*}{207} \\
\hline & Sample D25-6730 & $<2.95$ & & & & \\
\hline \multirow[t]{2}{*}{ GEA.w. ${ }^{40} \mathrm{~K}$} & Sample D25-7730 & $(0.324)$ & \multirow{2}{*}{$\begin{array}{c}0.0324 \\
\text { to } \\
0.0396\end{array}$} & \multirow[t]{2}{*}{0.340} & \multirow[t]{2}{*}{0.0189} & \\
\hline & Sample D33-7730 & $(0.396)$ & & & & \\
\hline \multirow[t]{2}{*}{ GEA.RS. ${ }^{40} \mathrm{~K}$} & Sample D37-9730 & $<0.0606$ & \multirow{2}{*}{$\begin{array}{c}<0.0606 \\
\text { to } \\
<0.0909\end{array}$} & \multirow[t]{2}{*}{$<0.0909$} & \multirow[t]{2}{*}{$N / A$} & \\
\hline & Sample D28-9730 & $(<0.0990)$ & & & & \\
\hline
\end{tabular}


Table A-3. Tank 241-T-105 Analytical Data: Plutonium-238

\begin{tabular}{|c|c|c|c|c|c|c||}
\hline Analyte & $\begin{array}{c}\text { Laboratory } \\
\text { Sample } \\
\text { Identification }\end{array}$ & $\begin{array}{c}\text { Analytical } \\
\text { Data } \\
\text { Result }\end{array}$ & $\begin{array}{c}\text { Range } \\
\text { of } \\
\text { Values }\end{array}$ & $\begin{array}{c}\text { Largest } \\
\text { Detection } \\
\text { Limit }\end{array}$ & $\begin{array}{c}\text { Standard } \\
\text { Deviation } \\
\text { (Mean) }\end{array}$ & $\begin{array}{c}\text { Projected } \\
\text { Inventory }\end{array}$ \\
\hline Radionuclide & & $\mu \mathrm{Ci} / \mathrm{g}$ & $\mu \mathrm{Ci} / \mathrm{g}$ & $\mu \mathrm{Ci} / \mathrm{g}$ & $\mu \mathrm{Ci} / \mathrm{g}$ & $\mathrm{Ci}$ \\
\hline AEA. ${ }^{238} \mathrm{Pu}$ & Sample D19-9730 & $(<2.45 \mathrm{E}-04)$ & $\mathrm{N} / \mathrm{A}$ & $<2.45 \mathrm{E}-04$ & $\mathrm{~N} / \mathrm{A}$ & $<0.149$ \\
\hline
\end{tabular}

Table A-3. Tank 241-T-105 Analytical Data: Plutonium-239/240

\begin{tabular}{|c|c|c|c|c|c|c|}
\hline Analyte & $\begin{array}{l}\text { Laboratory } \\
\text { Sample } \\
\text { Identification }\end{array}$ & $\begin{array}{c}\text { Analytical } \\
\text { Data } \\
\text { Result }\end{array}$ & $\begin{array}{c}\text { Range } \\
\text { of } \\
\text { Values }\end{array}$ & Mean & $\begin{array}{c}\text { Standard } \\
\text { Deviation } \\
\text { (Mean) }\end{array}$ & $\begin{array}{l}\text { Projected } \\
\text { Inventory }\end{array}$ \\
\hline $\begin{array}{l}\text { Radionuclide } \\
\text { (Liquid) }\end{array}$ & & $\mu \mathrm{Ci} / \mathrm{mL}$ & $\mu \mathrm{Ci} / \mathrm{mL}$ & $\mu \mathrm{Ci} / \mathrm{mL}$ & $\mu \mathrm{Ci} / \mathrm{mL}$ & $\mathrm{Ci}$ \\
\hline $\begin{array}{r}\text { Alpha Spec.d. } \\
239 / 240 \mathrm{Pu}\end{array}$ & Sample D19-5781 & $(1.88 E-04)$ & N/A & $1.88 \mathrm{E}-04$ & N/A & 84.5 \\
\hline $\begin{array}{l}\text { Radionuclide } \\
\text { (Solid) }\end{array}$ & & $\mu \mathrm{Ci} / \mathrm{g}$ & $\mu \mathrm{Ci} / \mathrm{g}$ & $\mu \mathrm{Ci} / \mathrm{g}$ & $\mu \mathrm{Ci} / \mathrm{g}$ & \\
\hline \multirow{2}{*}{$\begin{array}{r}\text { Alpha Spec.f. } \\
239 / 240 \mathrm{Pu}\end{array}$} & Sample D25-6781 & 0.136 & \multirow{2}{*}{$\begin{array}{l}0.136 \\
\text { to } \\
0.141\end{array}$} & \multirow[t]{2}{*}{0.139} & \multirow[t]{2}{*}{ N/A } & \\
\hline & Sample D33-6781 & 0.141 & & & & \\
\hline
\end{tabular}

Table A-3. Tank 241-T-105 Analytical Data: Ruthenium-103

\begin{tabular}{|c|c|c|c|c|c|c|}
\hline Analyte & $\begin{array}{l}\text { Laboratory } \\
\text { Sample } \\
\text { Identification }\end{array}$ & $\begin{array}{c}\text { Analytical } \\
\text { Data } \\
\text { Result }\end{array}$ & $\begin{array}{c}\text { Range } \\
\text { of } \\
\text { Values }\end{array}$ & $\begin{array}{c}\text { Largest } \\
\text { Detection } \\
\text { Limit }\end{array}$ & $\begin{array}{c}\text { Standard } \\
\text { Deviation } \\
\text { (Mean) }\end{array}$ & $\begin{array}{l}\text { Projected } \\
\text { Inventory }\end{array}$ \\
\hline Radionuclide & & $\mu \mathrm{Ci} / \mathrm{g}$ & $\mu \mathrm{Ci} / \mathrm{g}$ & $\mu \mathrm{Ci} / \mathrm{g}$ & $\mu \mathrm{Ci} / \mathrm{g}$ & $\mathrm{Ci}$ \\
\hline \multirow[t]{2}{*}{ GEA.f. ${ }^{103} \mathrm{Ru}$} & Sample D33-6730 & $<0.0236$ & \multirow{2}{*}{$\begin{array}{c}<0.0236 \\
\text { to } \\
<0.164\end{array}$} & \multirow[t]{2}{*}{$<0.164$} & \multirow[t]{2}{*}{ N/A } & \multirow[t]{6}{*}{$<99.7$} \\
\hline & Sample D25-6730 & $<0.164$ & & & & \\
\hline \multirow[t]{2}{*}{ GEA.w. ${ }^{103} R u$} & Sample D25-7730 & $<0.0354$ & \multirow{2}{*}{$\begin{array}{c}<0.0275 \\
\text { to } \\
<0.0354\end{array}$} & \multirow[t]{2}{*}{$<0.0354$} & \multirow[t]{2}{*}{ N/A } & \\
\hline & Sample D33-7730 & $<0.0275$ & & & & \\
\hline \multirow{2}{*}{$\begin{array}{r}\text { GEA.RS. } \\
{ }^{103} \mathrm{Ru}\end{array}$} & Sample D37-9730 & $<0.0245$ & \multirow{2}{*}{$\begin{array}{c}<0.0245 \\
\text { to } \\
<0.0438\end{array}$} & \multirow[t]{2}{*}{$<0.0438$} & \multirow[t]{2}{*}{ N/A } & \\
\hline & Sample D28-9730 & $<0.0438$ & & & & \\
\hline
\end{tabular}


Table A-3. Tank 241-T-105 Analytical Data: Ruthenium/Rhodium-106

\begin{tabular}{|c|c|c|c|c|c|c|}
\hline Analyte & $\begin{array}{l}\text { Laboratory } \\
\text { Sample } \\
\text { Identification }\end{array}$ & $\begin{array}{c}\text { Analytical } \\
\text { Data } \\
\text { Result }\end{array}$ & $\begin{array}{c}\text { Range } \\
\text { of } \\
\text { Values }\end{array}$ & $\begin{array}{l}\text { Largest } \\
\text { Detection } \\
\text { Limit }\end{array}$ & $\begin{array}{c}\text { Standard } \\
\text { Deviation } \\
\text { (Mean) }\end{array}$ & $\begin{array}{l}\text { Projected } \\
\text { Inventory }\end{array}$ \\
\hline Radionuclide & & $\mu \mathrm{Ci} / \mathrm{g}$ & $\mu \mathrm{Ci} / \mathrm{g}$ & $\mu \mathrm{Ci} / \mathrm{g}$ & $\mu \mathrm{Ci} / \mathrm{g}$ & $\mathrm{Ci}$ \\
\hline \multirow{2}{*}{$\begin{array}{l}\text { GEA.f. } \\
{ }^{106} \text { RuRh }\end{array}$} & Sample D33-6730 & $<0.310$ & \multirow{2}{*}{$\begin{array}{c}<0.310 \\
\text { to } \\
<2.14\end{array}$} & \multirow[t]{2}{*}{$<2.14$} & \multirow[t]{2}{*}{ N/A } & \multirow[t]{6}{*}{$<1,300$} \\
\hline & Sample D25-6730 & $<2.14$ & & & & \\
\hline \multirow{2}{*}{$\begin{array}{l}\text { GEA.W. } \\
{ }^{106} \text { RuRh }\end{array}$} & Sample D25-7730 & $<0.482$ & \multirow{2}{*}{$\begin{array}{c}<0.391 \\
\text { to } \\
<0.482\end{array}$} & \multirow[t]{2}{*}{$<0.482$} & \multirow[t]{2}{*}{ N/A } & \\
\hline & Sample D33-7730 & $<0.391$ & & & & \\
\hline \multirow{2}{*}{$\begin{array}{l}\text { GEA.RS. } \\
{ }^{106} \text { RuRh }\end{array}$} & Sample D37-9730 & $<0.310$ & \multirow{2}{*}{$\begin{array}{c}<0.310 \\
\text { to } \\
<0.621 \\
\end{array}$} & \multirow[t]{2}{*}{$<0.621$} & \multirow[t]{2}{*}{ N/A } & \\
\hline & Sample D28-9730 & $<0.621$ & & & & \\
\hline
\end{tabular}

Table A-3. Tank 241-T-105 Analytical Data: Strontium-90

\begin{tabular}{|c|c|c|c|c|c|c|}
\hline Analyte & $\begin{array}{l}\text { Laboratory } \\
\text { Sample } \\
\text { Identification }\end{array}$ & $\begin{array}{c}\text { Analytical } \\
\text { Data } \\
\text { Result }\end{array}$ & $\begin{array}{c}\text { Range } \\
\text { of } \\
\text { Values }\end{array}$ & Mean & $\begin{array}{c}\text { Standard } \\
\text { Deviation } \\
\text { (Mean) }\end{array}$ & $\begin{array}{l}\text { Projected } \\
\text { Inventory }\end{array}$ \\
\hline $\begin{array}{l}\text { Radionuclide } \\
\text { (Liquid) }\end{array}$ & & $\mu \mathrm{Ci} / \mathrm{mL}$ & $\mu \mathrm{Ci} / \mathrm{mL}$ & $\mu \mathrm{Ci} / \mathrm{mL}$ & $\mu \mathrm{Ci} / \mathrm{mL}$ & $\mathrm{Ci}$ \\
\hline BPC.d. ${ }^{90} \mathrm{Sr}$ & Sample D19-5786 & $(0.373)$ & $N / A$ & 0.373 & N/A & \multirow[t]{4}{*}{$1.71 \mathrm{E}+05$} \\
\hline $\begin{array}{l}\text { Radionuclide } \\
\text { (Solid) }\end{array}$ & & $\mu \mathrm{Ci} / \mathrm{g}$ & $\mu \mathrm{Ci} / \mathrm{g}$ & $\mu \mathrm{Ci} / \mathrm{g}$ & $\mu \mathrm{Ci} / \mathrm{g}$ & \\
\hline \multirow[t]{2}{*}{ BPC.d. ${ }^{90} \mathrm{Sr}$} & Sample D25-6786 & $(401)$ & \multirow{2}{*}{$\begin{array}{l}160 \\
\text { to } \\
401\end{array}$} & \multirow[t]{2}{*}{281} & \multirow[t]{2}{*}{ N/A } & \\
\hline & Sample D33-6786 & $(160)$ & & & & \\
\hline
\end{tabular}


WHC-SD-WM-ER-369 REV O

Table A-3. Tank 241-T-105 Analytical Data: Technicium-99

\begin{tabular}{|c|c|c|c|c|c|c|}
\hline Analyte & $\begin{array}{c}\text { Laboratory } \\
\text { Sample } \\
\text { Identification }\end{array}$ & $\begin{array}{c}\text { Analytical } \\
\text { Data } \\
\text { Result }\end{array}$ & $\begin{array}{c}\text { Range } \\
\text { of } \\
\text { Values }\end{array}$ & Mean & $\begin{array}{c}\text { Standard } \\
\text { Deviation } \\
\text { (Mean) }\end{array}$ & $\begin{array}{l}\text { Projected } \\
\text { Inventory }\end{array}$ \\
\hline $\begin{array}{l}\text { Radionuclide } \\
\text { (Liquid) }\end{array}$ & & $\mu \mathrm{Ci} / \mathrm{mL}$ & $\mu \mathrm{Ci} / \mathrm{mL}$ & $\mu \mathrm{Ci} / \mathrm{mL}$ & $\mu \mathrm{Ci} / \mathrm{mL}$ & $\mathrm{Ci}$ \\
\hline LSC.d. ${ }^{99} \mathrm{Tc}$ & Sample D19-5784 & $(0.0627)$ & N/A & 0.0627 & N/A & \multirow[t]{4}{*}{226} \\
\hline $\begin{array}{l}\text { Radionuclide } \\
\text { (Solid) }\end{array}$ & & $\mu \mathrm{Ci} / \mathrm{g}$ & $\mu \mathrm{Ci} / \mathrm{g}$ & $\mu \mathrm{Ci} / \mathrm{g}$ & $\mu \mathrm{Ci} / \mathrm{g}$ & \\
\hline \multirow[t]{2}{*}{ LSC.f. ${ }^{99} \mathrm{Tc}$} & Sample D25-6784 & $(<0.170)$ & \multirow{2}{*}{$\begin{array}{c}<0.170 \\
\text { to } \\
0.372\end{array}$} & \multirow[t]{2}{*}{0.372} & \multirow[t]{2}{*}{ N/A } & \\
\hline & Sample D33-6784 & $(0.372)$ & & & & \\
\hline
\end{tabular}

Table A-3. Tank 241-T-105 Analytical Data: Thorium-228

\begin{tabular}{|c|c|c|c|c|c|c|}
\hline Analyte & $\begin{array}{l}\text { Laboratory } \\
\text { Sample } \\
\text { Identification }\end{array}$ & $\begin{array}{c}\text { Analytical } \\
\text { Data } \\
\text { Result }\end{array}$ & $\begin{array}{c}\text { Range } \\
\text { of } \\
\text { Values }\end{array}$ & $\begin{array}{c}\text { Largest } \\
\text { Detection } \\
\text { Limit }\end{array}$ & $\begin{array}{c}\text { Standard } \\
\text { Deviation } \\
\text { (Mean) }\end{array}$ & $\begin{array}{l}\text { Projected } \\
\text { Inventory }\end{array}$ \\
\hline Radionuclide & & $\mu \mathrm{Ci} / \mathrm{g}$ & $\mu \mathrm{Ci} / \mathrm{g}$ & $\mu \mathrm{Ci} / \mathrm{g}$ & $\mu \mathrm{Ci} / \mathrm{g}$ & $\mathrm{Ci}$ \\
\hline \multirow[t]{2}{*}{ GEA.f. ${ }^{228} \mathrm{Th}$} & Sample D33-6730 & $<0.0355$ & \multirow{2}{*}{$\begin{array}{c}<0.0355 \\
\text { to } \\
<0.268\end{array}$} & \multirow[t]{2}{*}{$<0.268$} & \multirow[t]{2}{*}{ N/A } & \multirow[t]{6}{*}{$<163$} \\
\hline & Sample D25-6730 & $<0.268$ & & & & \\
\hline \multirow[t]{2}{*}{ GEA.w. ${ }^{228} T h$} & Sample D25-7730 & $<0.0517$ & \multirow{2}{*}{$\begin{array}{c}<0.0414 \\
\text { to } \\
<0.0517\end{array}$} & \multirow[t]{2}{*}{$<0.0517$} & \multirow[t]{2}{*}{ N/A } & \\
\hline & Sample D33-7730 & $<0.0414$ & & & & \\
\hline \multirow{2}{*}{$\begin{array}{r}\text { GEA.RS. } \\
{ }^{228} \mathrm{Th}\end{array}$} & Sample D37-9730 & $<0.0456$ & \multirow{2}{*}{$\begin{array}{c}<0.0456 \\
\text { to } \\
<0.0828\end{array}$} & \multirow[t]{2}{*}{$<0.0828$} & \multirow[t]{2}{*}{ N/A } & \\
\hline & Sample D28-9730 & $<0.0828$ & & & & \\
\hline
\end{tabular}


Table A-3. Tank 241-T-105 Analytical Data: Tritium

\begin{tabular}{|c|c|c|c|c|c|c|}
\hline Analyte & $\begin{array}{l}\text { Laboratory } \\
\text { Sample } \\
\text { Identification }\end{array}$ & $\begin{array}{c}\text { Analytical } \\
\text { Data } \\
\text { Result }\end{array}$ & $\begin{array}{c}\text { Range } \\
\text { of } \\
\text { Values }\end{array}$ & $\dot{P}$ & $\begin{array}{l}\text { Standard } \\
\text { Deviation } \\
\text { (Mean) }\end{array}$ & $\begin{array}{l}\text { Projected } \\
\text { Inventory }\end{array}$ \\
\hline Radionuclide & & $\mu \mathrm{Ci} / \mathrm{g}$ & $\mu \mathrm{Ci} / \mathrm{g}$ & $\mu \mathrm{Ci} / \mathrm{g}$ & $\mu \mathrm{Ci} / \mathrm{g}$ & $\mathrm{Ci}$ \\
\hline \multirow[t]{2}{*}{ LSC.w. ${ }^{3} \mathrm{H}$} & Sample D28-7787 & $(0.0240)$ & \multirow{2}{*}{$\begin{array}{c}8.67 \mathrm{E}-04 \\
\text { to } \\
0.0240\end{array}$} & \multirow[t]{2}{*}{0.0124} & \multirow[t]{2}{*}{0.0116} & \multirow[t]{2}{*}{7.54} \\
\hline & Sample D37-7787 & (8.67E-04) & & & & \\
\hline
\end{tabular}

Table A-3. Tank 241-T-105 Analytical Data: Total Alpha

\begin{tabular}{|c|c|c|c|c|c|c|}
\hline Analyte & $\begin{array}{c}\text { Laboratory } \\
\text { Sample } \\
\text { Identification }\end{array}$ & $\begin{array}{c}\text { Analytical } \\
\text { Data } \\
\text { Result }\end{array}$ & $\begin{array}{c}\text { Range } \\
\text { of } \\
\text { Values }\end{array}$ & Mean & $\begin{array}{c}\text { Standard } \\
\text { Deviation } \\
\text { (Mean) }\end{array}$ & $\begin{array}{l}\text { Projected } \\
\text { Inventory }\end{array}$ \\
\hline $\begin{array}{l}\text { Radionuclide } \\
\text { (Liquid) }\end{array}$ & & $\mu \mathrm{Ci} / \mathrm{mL}$ & $\mu \mathrm{Ci} / \mathrm{mL}$ & $\mu \mathrm{Ci} / \mathrm{mL}$ & $\mu \mathrm{Ci} / \mathrm{mL}$ & $\mathrm{Ci}$ \\
\hline $\begin{array}{l}\text { APC.d. } \\
\text { Tot Alpha }\end{array}$ & Sample D33-6730 & $<0.0355$ & N/A & $<0.0355$ & N/A & \multirow[t]{6}{*}{169} \\
\hline $\begin{array}{l}\text { Radionuclide } \\
\text { (Solid) }\end{array}$ & & $\mu \mathrm{Ci} / \mathrm{g}$ & $\mu \mathrm{Ci} / \mathrm{g}$ & $\mu \mathrm{Ci} / \mathrm{g}$ & $\mu \mathrm{Ci} / \mathrm{g}$ & \\
\hline \multirow{2}{*}{$\begin{array}{l}\text { APC.W. } \\
\text { Tot Alpha }\end{array}$} & Sample D25-7725 & $(0.00539)$ & \multirow{2}{*}{$\begin{array}{c}0.00342 \\
\text { to } \\
0.00539\end{array}$} & \multirow[t]{2}{*}{0.00440} & \multirow[t]{2}{*}{ 9.87E-04 } & \\
\hline & Sample D33-7725 & $(0.00342)$ & & & & \\
\hline \multirow{2}{*}{$\begin{array}{r}\text { APC.f. } \\
\text { Tot Alpha }\end{array}$} & Sample D25-6725 & $(0.0819)$ & \multirow{2}{*}{$\begin{array}{c}0.474 \\
\text { to } \\
0.0819 \\
\end{array}$} & \multirow[t]{2}{*}{0.278} & \multirow[t]{2}{*}{ N/A } & \\
\hline & Sample D33-6725 & $(0.474)$ & & & & \\
\hline
\end{tabular}

Table A-3. Tank 241-T-105 Analytical Data: Total Beta

\begin{tabular}{|c|c|c|c|c|c|c|}
\hline Analyte & $\begin{array}{l}\text { Laboratory } \\
\text { Sample } \\
\text { Identification }\end{array}$ & $\begin{array}{c}\text { Analytical } \\
\text { Data } \\
\text { Result }\end{array}$ & $\begin{array}{c}\text { Range } \\
\text { of } \\
\text { Values }\end{array}$ & Mean & $\begin{array}{c}\text { Standard } \\
\text { Deviation } \\
\text { (Mean) }\end{array}$ & $\begin{array}{l}\text { Projected } \\
\text { Inventory }\end{array}$ \\
\hline $\begin{array}{l}\text { Radionuclide } \\
\text { (Liquid) }\end{array}$ & & $\mu \mathrm{Ci} / \mathrm{mL}$ & $\mu \mathrm{Ci} / \mathrm{mL}$ & $\mu \mathrm{Ci} / \mathrm{mL}$ & $\mu \mathrm{Ci} / \mathrm{mL}$ & $\mathrm{Ci}$ \\
\hline $\begin{array}{r}\text { BPC.d. } \\
\text { Tot Beta }\end{array}$ & Sample D19-5720 & $(23.6)$ & N/A & 23.6 & $N / A$ & \multirow[t]{6}{*}{$5.27 E+05$} \\
\hline $\begin{array}{l}\text { Radionuclide } \\
\text { (Solid) }\end{array}$ & & $\mu \mathrm{Ci} / \mathrm{g}$ & $\mu \mathrm{Ci} / \mathrm{g}$ & $\mu \mathrm{Ci} / \mathrm{g}$ & $\mu \mathrm{Ci} / \mathrm{g}$ & \\
\hline \multirow{2}{*}{$\begin{array}{l}\text { BPC.w. } \\
\text { Tot Beta }\end{array}$} & Sample D25-7720 & $(48.5)$ & \multirow{2}{*}{$\begin{array}{l}26.8 \\
\text { to } \\
48.5\end{array}$} & \multirow[t]{2}{*}{37.7} & \multirow[t]{2}{*}{10.9} & \\
\hline & Sample D33-7720 & $(26.8)$ & & & & \\
\hline \multirow{2}{*}{$\begin{array}{l}\text { BPC.f. } \\
\text { Tot Beta }\end{array}$} & Sample D25-6720 & $(1,260)$ & \multirow{2}{*}{$\begin{array}{c}471 \\
\text { to } \\
1,260\end{array}$} & \multirow[t]{2}{*}{866} & \multirow[t]{2}{*}{ N/A } & \\
\hline & Sample D33-6720 & $(471)$ & & & & \\
\hline
\end{tabular}


Table A-3. Tank 241-T-105 Analytical Data: Percentage Plutonium

\begin{tabular}{|c|c|c|}
\hline $\begin{array}{c}\text { Laboratory } \\
\text { Sample } \\
\text { Identification }\end{array}$ & Analyte & $\begin{array}{c}\text { Analytical } \\
\text { Data } \\
\text { Result } \\
\end{array}$ \\
\hline PNL & Radionuclide & $\%$ \\
\hline \multirow[t]{5}{*}{$93-7985$} & Mass Spec. ${ }^{238} \mathrm{Pu}$ & 0.193 \\
\hline & Mass Spec. ${ }^{239} \mathrm{Pu}$ & 96.469 \\
\hline & Mass Spec. ${ }^{240} \mathrm{Pu}$ & 3.188 \\
\hline & Mass Spec. ${ }^{241} \mathrm{Pu}$ & 0.11 \\
\hline & Mass Spec. ${ }^{242} \mathrm{Pu}$ & 0.04 \\
\hline
\end{tabular}

Table A-3. Tank 241-T-105 Analytical Data: Percentage Uranium

\begin{tabular}{|r|c|c|}
\hline \multicolumn{1}{|c|}{$\begin{array}{c}\text { Laboratory } \\
\text { Sample } \\
\text { Identification }\end{array}$} & Analyte & $\begin{array}{c}\text { Analytical } \\
\text { Data } \\
\text { Result }\end{array}$ \\
\hline PNL & Radionuclide & $\%$ \\
\hline \multirow{2}{*}{$93-7985$} & Mass Spec. ${ }^{234} \mathrm{U}$ & 0.006 \\
\cline { 2 - 4 } & Mass Spec. ${ }^{235} \mathrm{U}$ & 0.688 \\
\cline { 2 - 4 } & Mass Spec. ${ }^{236} \mathrm{U}$ & 0.006 \\
\cline { 2 - 4 } & Mass Spec. ${ }^{238} \mathrm{U}$ & 99.300 \\
\hline
\end{tabular}

Table A-4. Tank 241-T-105 Analytical Data: pH

\begin{tabular}{|c|c|c|c|c|c|}
\hline Analyte & $\begin{array}{l}\text { Laboratory } \\
\text { Sample } \\
\text { Identification }\end{array}$ & $\begin{array}{c}\text { Analytical } \\
\text { Data } \\
\text { Result }\end{array}$ & $\begin{array}{c}\text { Range } \\
\text { of } \\
\text { Values }\end{array}$ & Mean & $\begin{array}{c}\text { Standard } \\
\text { Deviation } \\
\text { (Mean) }\end{array}$ \\
\hline \multicolumn{6}{|l|}{$\begin{array}{l}\text { Physical } \\
\text { Property }\end{array}$} \\
\hline \multirow{2}{*}{$\begin{array}{c}\mathrm{pH} \\
\text { (Liquid) }\end{array}$} & Sample D19-5713 & $(12.01)$ & \multirow{2}{*}{$\begin{array}{c}8.28 \\
\text { to } \\
12.01\end{array}$} & \multirow[t]{2}{*}{--} & \multirow[t]{2}{*}{--} \\
\hline & Sample D22-5713 & $(8.28)$ & & & \\
\hline \multirow{2}{*}{$\begin{array}{r}\mathrm{pH} \\
\text { (Segment) }\end{array}$} & Sample D25-5715 & $(11.29)$ & \multirow{2}{*}{$\begin{array}{c}11.29 \\
\text { to } \\
12.06\end{array}$} & \multirow[t]{2}{*}{11.7} & \multirow[t]{2}{*}{ N/A } \\
\hline & Sample D33-5715 & $(12.06)$ & & & \\
\hline
\end{tabular}


Table A-4. Tank 241-T-105 Analytical Data: Specific Gravity

\begin{tabular}{|c|c|c|c|c|c|}
\hline Analyte & $\begin{array}{c}\text { Laboratory } \\
\text { Sample } \\
\text { Identification }\end{array}$ & $\begin{array}{c}\text { Analytical } \\
\text { Data } \\
\text { Result } \\
\end{array}$ & $\begin{array}{c}\text { Range. } \\
\text { of } \\
\text { Values }\end{array}$ & Mean & $\begin{array}{c}\text { Standard } \\
\text { Deviation } \\
\text { (Mean) }\end{array}$ \\
\hline \multicolumn{6}{|l|}{$\begin{array}{l}\text { Physical } \\
\text { Property }\end{array}$} \\
\hline \multirow[t]{2}{*}{ SpG } & Sample D19-5706 & 1.05 & \multirow{2}{*}{$\begin{array}{c}0.985 \\
\text { to } \\
1.05\end{array}$} & \multirow[t]{2}{*}{1.02} & \multirow[t]{2}{*}{ N/A } \\
\hline & Sample D22-5706 & 0.985 & & & \\
\hline
\end{tabular}

Table A-4. Tank 241-T-105 Analytical Data: Thermo-Gravimetric Analysis

\begin{tabular}{|c|c|c|c|c|c|}
\hline Analyte & $\begin{array}{l}\text { Laboratory } \\
\text { Sample } \\
\text { Identification }\end{array}$ & $\begin{array}{c}\begin{array}{c}\text { Analytical } \\
\text { Data } \\
\text { Result }\end{array} \\
\end{array}$ & $\begin{array}{c}\begin{array}{c}\text { Range } \\
\text { of } \\
\text { Values }\end{array} \\
\end{array}$ & Mean & $\begin{array}{c}\text { Standard } \\
\text { Deviation } \\
\text { (Mean) }\end{array}$ \\
\hline $\begin{array}{l}\text { Physical } \\
\text { Property }\end{array}$ & & $\%$ & $\%$ & $\%$ & $\%$ \\
\hline \multirow[t]{3}{*}{ TGA } & Sample D19-5712 & 91.39 & \multirow{3}{*}{$\begin{array}{c}35.52 \\
\text { to } \\
91.39\end{array}$} & \multirow[t]{3}{*}{59.61} & \multirow[t]{3}{*}{28.71} \\
\hline & Sample D9-5712 & 51.97 & & & \\
\hline & Sample D8-5712 & 35.52 & & & \\
\hline
\end{tabular}

Table A-4. Tank 241-T-105 Analytical Data: Total Dissolved Solid

\begin{tabular}{|c|c|c|c|c|c|}
\hline Analyte & $\begin{array}{l}\text { Laboratory } \\
\text { Sample } \\
\text { Identification }\end{array}$ & $\begin{array}{c}\text { Analytical } \\
\text { Data } \\
\text { Result }\end{array}$ & $\begin{array}{c}\text { Range } \\
\text { of } \\
\text { Values }\end{array}$ & Mean & $\begin{array}{c}\text { Standard } \\
\text { Deviation } \\
\text { (Mean) }\end{array}$ \\
\hline $\begin{array}{l}\text { Physical } \\
\text { Property }\end{array}$ & & $\%$ & $\%$ & $\%$ & $\%$ \\
\hline \multirow[t]{2}{*}{ TDS } & Sample D25-7705 & 0.280 & \multirow{2}{*}{$\begin{array}{c}0.105 \\
\text { to } \\
0.280\end{array}$} & \multirow[t]{2}{*}{0.193} & \multirow[t]{2}{*}{0.0875} \\
\hline & Sample D33-7705 & $(0.105)$ & & & \\
\hline
\end{tabular}


Table A-4. Tank 241-T-105 Analytical Data: Weight Percent Solid

\begin{tabular}{||c|c|c|c|c|c||}
\hline Analyte & $\begin{array}{c}\text { Laboratory } \\
\text { Sample } \\
\text { Identification }\end{array}$ & $\begin{array}{c}\text { Analytical } \\
\text { Data } \\
\text { Result }\end{array}$ & $\begin{array}{c}\text { Range } \\
\text { of } \\
\text { Values }\end{array}$ & $\%$ & $\begin{array}{c}\text { Standard } \\
\text { Deviation } \\
\text { (Mean) }\end{array}$ \\
\hline $\begin{array}{r}\text { Physical } \\
\text { Property }\end{array}$ & & $\%$ & $\%$ & $\%$ \\
\hline $\begin{array}{r}\text { Wt \% Solid } \\
\text { (222-S) }\end{array}$ & Sample D33-5710 & 73.39 & N/A & 73.39 & N/A \\
\hline $\begin{array}{r}\text { Wt \%olid } \\
\text { (PNL) }\end{array}$ & Sample 93-07985 & 74.9 & N/A & 74.9 & N/A \\
\hline
\end{tabular}

Table A-4. Tank 241-T-105 Analytical Data: Total Solid

\begin{tabular}{|c|c|c|c|c|c|}
\hline Analyte & $\begin{array}{l}\text { Laboratory } \\
\text { Sample } \\
\text { Identification }\end{array}$ & $\begin{array}{c}\text { Analytical } \\
\text { Data } \\
\text { Result }\end{array}$ & $\begin{array}{c}\text { Range } \\
\text { of } \\
\text { Values }\end{array}$ & Mean & $\begin{array}{c}\text { Standard } \\
\text { Deviation } \\
\text { (Mean) }\end{array}$ \\
\hline $\begin{array}{l}\text { Physical } \\
\text { Property }\end{array}$ & & $\%$ & $\%$ & $\%$ & $\%$ \\
\hline \multirow{2}{*}{$\begin{array}{r}\text { Wt \% Total } \\
\text { Solid }\end{array}$} & Sample 07987 & 52.0 & \multirow{2}{*}{$\begin{array}{c}52.0 \\
\text { to } \\
75.0\end{array}$} & \multirow[t]{2}{*}{63.5} & \multirow[t]{2}{*}{ N/A } \\
\hline & Sample 07988 & 75.0 & & & \\
\hline
\end{tabular}

Table A-4. Tank 241-T-105 Analytical Data: Centrifuged Solid

\begin{tabular}{|c|c|c|c|c|c|}
\hline Analyte & $\begin{array}{l}\text { Laboratory } \\
\text { Sample } \\
\text { Identification }\end{array}$ & $\begin{array}{c}\text { Analytical } \\
\text { Data } \\
\text { Result }\end{array}$ & $\begin{array}{c}\text { Range } \\
\text { of } \\
\text { Values }\end{array}$ & Mean & $\begin{array}{c}\text { Standard } \\
\text { Deviation } \\
\text { (Mean) }\end{array}$ \\
\hline $\begin{array}{l}\text { Physical } \\
\text { Property }\end{array}$ & & $\%$ & $\%$ & $\%$ & $\%$ \\
\hline \multirow{2}{*}{$\begin{array}{r}\text { Wt \% } \\
\text { Centrifuge } \\
\text { Solid }\end{array}$} & Sample 07987 & 96 & \multirow{2}{*}{$\begin{array}{l}96 \\
\text { to } \\
98\end{array}$} & \multirow[t]{2}{*}{97} & \multirow[t]{2}{*}{$N / A$} \\
\hline & Sample 07988 & 98 & & & \\
\hline
\end{tabular}


Table A-4. Tank 241-T-105 Analytical Data: Residual Solid

\begin{tabular}{||c|c|c|c|c|c||}
\hline Analyte & $\begin{array}{c}\text { Laboratory } \\
\text { Sample } \\
\text { Identification }\end{array}$ & $\begin{array}{c}\text { Analytical } \\
\text { Data } \\
\text { Result }\end{array}$ & $\begin{array}{c}\text { Range } \\
\text { of } \\
\text { Values }\end{array}$ & $\begin{array}{c}\text { Mean } \\
\text { Standard } \\
\text { Deviation } \\
\text { (Mean) }\end{array}$ \\
\hline $\begin{array}{r}\text { Physical } \\
\text { Property }\end{array}$ & $\%$ & $\%$ & $\%$ & N/A \\
\hline $\begin{array}{r}\text { Wesidual } \% \\
\text { Solid }\end{array}$ & Sample D37-9710 & $(52.72)$ & N/A & 52.72 & \\
\hline
\end{tabular}

Table A-4. Tank 241-T-105 Analytical Data: Density

\begin{tabular}{|c|c|c|c|c|c|}
\hline Analyte & $\begin{array}{l}\text { Laboratory } \\
\text { Sample } \\
\text { Identification }\end{array}$ & $\begin{array}{c}\text { Analytical } \\
\text { Data } \\
\text { Result }\end{array}$ & $\begin{array}{c}\text { Range } \\
\text { of } \\
\text { Values }\end{array}$ & Mean & $\begin{array}{c}\text { Standard } \\
\text { Deviation } \\
\text { (Mean) }\end{array}$ \\
\hline $\begin{array}{l}\text { Physical } \\
\text { Property }\end{array}$ & & $\mathrm{g} / \mathrm{mL}$ & $\mathrm{g} / \mathrm{mL}$ & $\mathrm{g} / \mathrm{mL}$ & $\mathrm{g} / \mathrm{mL}$ \\
\hline \multirow[t]{2}{*}{ Density } & Sample 07987 & 1.54 & \multirow{2}{*}{$\begin{array}{l}1.54 \\
\text { to } \\
1.74 \\
\end{array}$} & \multirow[t]{2}{*}{1.64} & \multirow[t]{2}{*}{$N / A$} \\
\hline & Sample 07988 & 1.74 & & & \\
\hline
\end{tabular}

Table A-4. Tank 241-T-105 Analytical Data: Total Inorganic Carbon

\begin{tabular}{|c|c|c|c|c|c|c|}
\hline Analyte & $\begin{array}{l}\text { Laboratory } \\
\text { Sample } \\
\text { Identification }\end{array}$ & $\begin{array}{c}\text { Analytical } \\
\text { Data } \\
\text { Result }\end{array}$ & $\begin{array}{c}\text { Range } \\
\text { of } \\
\text { Values }\end{array}$ & Mean & $\begin{array}{c}\text { Standard } \\
\text { Deviation } \\
\text { (Mean) }\end{array}$ & $\begin{array}{l}\text { Projected } \\
\text { Inventory }\end{array}$ \\
\hline $\begin{array}{l}\text { Physical } \\
\text { Property } \\
\text { (Liquid) }\end{array}$ & & $\mu \mathrm{g} / \mathrm{mL}$ & $\mu \mathrm{g} / \mathrm{mL}$ & $\mu \mathrm{g} / \mathrm{mL}$ & $\mu \mathrm{g} / \mathrm{mL}$ & $\mathrm{kg}$ \\
\hline \multirow[t]{2}{*}{ TIC } & Sample D19-5727 & $(2,990)$ & \multirow{2}{*}{$\begin{array}{c}2,990 \\
\text { to } \\
3,680\end{array}$} & \multirow[t]{2}{*}{3,340} & \multirow[t]{2}{*}{ N/A } & \multirow[t]{7}{*}{4,660} \\
\hline & Sample D33-7727 & $(3,680)$ & & & & \\
\hline $\begin{array}{l}\text { Physical } \\
\text { Property } \\
\text { (Solid) }\end{array}$ & & $\mu g / g$ & $\mu \mathrm{g} / \mathrm{g}$ & $\mu \mathrm{g} / \mathrm{g}$ & $\mu \mathrm{g} / \mathrm{g}$ & \\
\hline $\operatorname{TIC}(222-\mathrm{S})$ & Sample D25-7727 & $(7,660)$ & N/A & 7,660 & N/A & \\
\hline \multirow[t]{3}{*}{ TIC (PNL) } & Sample 93-07987 & $(3,860)$ & \multirow{3}{*}{$\begin{array}{c}3,250 \\
\text { to } \\
4,790\end{array}$} & \multirow[t]{3}{*}{3,970} & \multirow[t]{3}{*}{ N/A } & \\
\hline & Sample 93-07988 & $(3,250)$ & & & & \\
\hline & Sample 93-07986 & $(4,790)$ & & & & \\
\hline
\end{tabular}


Table A-4. Tank 241-T-105 Analytical Data: Total Organic Carbon

\begin{tabular}{|c|c|c|c|c|c|c|}
\hline Analyte & $\begin{array}{c}\text { Laboratory } \\
\text { Sample } \\
\text { Identification }\end{array}$ & $\begin{array}{c}\text { Analytical } \\
\text { Data } \\
\text { Result } \\
\end{array}$ & $\begin{array}{c}\text { Range } \\
\text { of } \\
\text { Values }\end{array}$ & Mean & $\begin{array}{c}\text { Standard } \\
\text { Deviation } \\
\text { (Mean) }\end{array}$ & $\begin{array}{l}\text { Projected } \\
\text { Inventory }\end{array}$ \\
\hline $\begin{array}{l}\text { Physical } \\
\text { Property } \\
\text { (Liquid) }\end{array}$ & & $\mu \mathrm{g} / \mathrm{mL}$ & $\mu \mathrm{g} / \mathrm{mL}$ & $\mu \mathrm{g} / \mathrm{mL}$ & $\mu \mathrm{g} / \mathrm{mL}$ & $\mathrm{kg}$ \\
\hline \multirow[t]{2}{*}{ TOC } & Sample D19-5726 & $(924)$ & \multirow{2}{*}{$\begin{array}{c}924 \\
\text { to } \\
5,060\end{array}$} & \multirow[t]{2}{*}{2,990} & \multirow[t]{2}{*}{ N/A } & \multirow[t]{7}{*}{2,510} \\
\hline & Sample D33-7726 & $(5,060)$ & & & & \\
\hline $\begin{array}{l}\text { Physical } \\
\text { Property } \\
\text { (Solid) }\end{array}$ & & $\mu \mathrm{g} / \mathrm{g}$ & $\mu \mathrm{g} / \mathrm{g}$ & $\mu \mathrm{g} / \mathrm{g}$ & $\mu \mathrm{g} / \mathrm{g}$ & \\
\hline TOC (222-S) & Sample D25-7726 & $(4,130)$ & N/A & 4,130 & N/A & \\
\hline \multirow[t]{3}{*}{ TOC (PNL) } & Sample 93-07987 & $(5,280)$ & \multirow{3}{*}{$\begin{array}{c}1,630 \\
\text { to } \\
5,280\end{array}$} & \multirow[t]{3}{*}{3,180} & \multirow[t]{3}{*}{ N/A } & \\
\hline & Sample 93-07988 & $(-1,630)$ & & & & \\
\hline & Sample 93-07986 & $(2,620)$ & & & & \\
\hline
\end{tabular}


WHC-SD-WM-ER-369 REV O

\section{APPENDIX B}

\section{MASS/CHARGE BALANCE}


The following was derived from Westinghouse Hanford Company document WHC-SD-WM-DP. 047, Rev. 0, Addendum 1A, Internal Memo 12110-PCL93-084, dated September 28, 1993.

Mass balance and charge balance calculations have been completed for tank T-105 samples representing core 53 segment 1 and core 54 segment 1 . Of the raw analytical data provided, the numbers necessary for calculating mass and charge balance are shown in Table 1. Table 2 shows the corresponding concentrations of the chemical compounds assumed to be present in the waste, and the results of the mass and charge balance calculations. For both core samples, the charge balance is good (close to 1.00 ), but the mass balances are somewhat low.

\section{Interpretation of Results}

For the core 53 acid digest analysis, the low mass balance $(92.6 \%)$ may be due to incomplete dissolution of the samples. The fact that the charge balance is excellent $(0.99)$ suggests a factor that influences the sample as a whole, such as incomplete dissolution, as opposed to an incorrect analytical result for one or more of the sample components.

The charge balance for the core 53 fusion analysis was lower than it was for the acid digest analysis. This fact reflects the lower sodium result for the fusion sample. One would expect these numbers to be the same, since sodium compounds should be completely dissolved in both treatments. Since the two sodium values (acid digest/fusion) differ by about $10 \%$, and the same value for anions is used for both samples, the difference in charge balance is also about $10 \%$. The higher overall mass balance for the fusion analysis reflects the higher aluminum result in the fusion.

There were no inductively coupled plasma spectroscopy (ICP) analyses done on the water digest sample for core 53 , so no mass or charge balances are possible.

The very low mass balance (38.5\%) for the core 54 water digest sample is due to incomplete dissolution, and is to be expected. The charge balance, which does not depend on complete sample dissolution, is excellent (0.96).

The ICP results for the core 54 acid digest and fusion samples show that aluminum is by far the major metal present in the samples. If the aluminum is present as $\mathrm{Al}(\mathrm{OH})_{3}$, as assumed, then it accounts for approximately half of the total sample as analyzed. [See Table $2 \ldots 0.445 \mathrm{~g} \mathrm{Al}(\mathrm{OH})_{3}$ out of $0.861 \mathrm{~g}$ total sample for the acid digest, and $0.437 \mathrm{~g} \mathrm{Al}(\mathrm{OH})_{3}$ out of $0.887 \mathrm{~g}$ total sample for the fusion]. The low mass balance for both of these samples is probably due to the unusually low weight percent water (26.61\%) reported for core 54 segment 1 , but could also be related to incomplete dissolution of the solids.

\section{Calculations and Assumptions}

The mass balance is calculated by the following formula, using the data shown in Table 2. The factor 0.0001 is equivalent to multiplying by $10^{6}$ to convert $\mu \mathrm{g} / \mathrm{g}$ into $\mathrm{g} / \mathrm{g}$, then dividing by 100 to convert $\mathrm{g} / \mathrm{g}$ to weight percent. The phosphate value in the formula comes from the ICP result, rather than the ion chromatography (IC) result, because it includes both water-soluble and water-insoluble phosphate (see "Bismuth" below). The values for the anions determined by water digest are used in both the acid digest and fusion mass balance calculations.

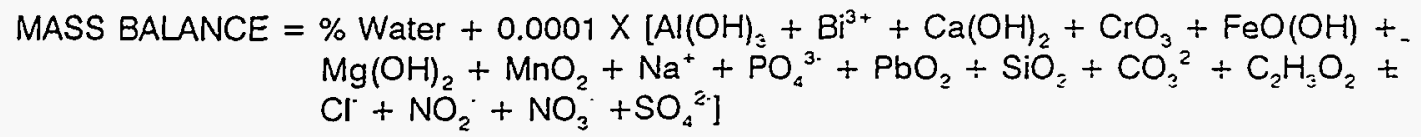


Elements or ions that were consistently below $500 \mu \mathrm{g} / \mathrm{g}$ in the data provided were not included in the calculations. Hydroxide was among the ions not included for that reason.

The charge balance is the ratio of the cation microequivalents to anion microequivalents. The only anion data available comes from the water digest analyses, and therefore the only cations that should be considered are those that are water soluble. The only significant cation that falls into this category is sodium (See the water digest ICP results in Table 1). Therefore, the calculations for total cation equivalents is simply the sodium concentration in $\mu \mathrm{g} / \mathrm{g}$ divided by equivalent weight, or atomic weight, of sodium.

There are many anions that balance the $\mathrm{Na}^{+}$charge. The calculation for the total microequivalents of anions is made by the following formula, in which the concentration of each ion (Table 2) is given in $\mu \mathrm{g} / \mathrm{g}$, and the phosphate value is taken from the $I C$ results:

TOTAL ANIONS (microequivalents) $=\left[\mathrm{CO}_{3}{ }^{2} / 30.0+\mathrm{C}_{2} \mathrm{H}_{3} \mathrm{O}_{2} / 59.0+\mathrm{Cl} / 35.4+\mathrm{NO}_{2} / 46.0+\mathrm{NO}_{3} / 62.0+\right.$ $\left.\mathrm{PO}_{4}^{3} / 31.7+\mathrm{SO}_{4}^{2} / 48.0\right]$

Aluminum is one of the major components of the samples. and is almost completely water-insoluble. Due to the low hydroxide concentration in the samples, the aluminum is assumed to be present in the original samples as $\mathrm{Al}(\mathrm{OH})_{3}$. While it is quite possible that some of the aluminum is present as aluminosilicate (zeolite), incorporating such species into the mass balance calculation would only lower the overall mass balance, rather than raise it. Therefore, in the interest of keeping the mass balance calculations as simple and consistent as possible, all of the aluminum is presumed to be $\mathrm{Al}(\mathrm{OH})_{3}$.

Bismuth is assumed to be present as water-insoluble $\mathrm{BiPO}_{4}$. Because the phosphate is listed as a separate entry in Table 2, the bismuth is listed in Table 2 as the bare ion for calculating the mass balance. The amount of phosphate determined by ICP, and included in Table 2. is more than enough to account for the water soluble sodium phosphate (as determined by the water digest IC) and the $\mathrm{BiPO}_{4}$.

Calcium is assumed to be present as $\mathrm{Ca}(\mathrm{OH})_{2}$. Other forms, such as $\mathrm{Ca}_{3}\left(\mathrm{PO}_{4}\right)_{2}$, are possible, but would lower the overall mass balance instead of raise it.

Chromium is a trace element in the samples. It was included only because it fell above the arbitrary $500 \mu \mathrm{g} / \mathrm{g}$ "cutoff" limit for one of the cores.

Iron is another major component, and is assumed to be present as $\mathrm{FeO}(\mathrm{OH})$. (See entry for "ferric hydroxide" in The Merck Index, Tenth Edition.) Any number of other forms are possible, which could raise or lower the mass balance by small amounts.

Magnesium is present in small amounts. It is assumed to be present as $\mathrm{Mg}(\mathrm{OH})_{2}$. Other forms are possible, but since Mg is present in such small concentration, they would have no significant effect on the mass balance.

Manqanese is assumed to be present as $\mathrm{MnO}_{2}$.

Sodium is calculated in both mass and charge balance as the bare $\mathrm{Na}^{*}$ ion. It is associated with the various anions listed as water-soluble salts. There may be traces of water-insoluble sodium. compounds, such as zeolites, but the close agreement between the water digest, ac!d digest. and fusion results for sodium in core 54 show that nearly all the sodium is water-soluble. 
Phosphorus is determined by ICP, and phosphate is determined by IC. In Table 2, the phosphorus ICP value was converted to phosphate, assuming that all the phosphorus was phosphate. The numbers in Table 2 show that, base on this assumption, the ICP value for phosphate is approximately twice as high as the IC value. This indicates that half of the phosphate is water-soluble (i.e., $\mathrm{Na}_{3} \mathrm{PO}_{4}$ ) and half is water in-soluble (e.g., $\mathrm{BiPO}_{4}$ ). The ICP values were used for all of the mass balance calculations, and the IC value was used for the charge balance calculations.

Lead is another trace element that barely made the "cutoff". It is assumed to be present as $\mathrm{P}_{\mathfrak{c}} \mathrm{O}_{\hat{z}}$.

Sulfur is present as the sulfate ion, and appears to be completely water soluble. The sulfate calculated from the ICP result is in good agreement with the sulfate analyzed by IC (see Table 2). The IC results were used for both mass balance and charge balance calculations.

Silicon is assumed to be present as $\mathrm{SiO}_{2}$. Analytical results were widely scattered. The water digest ICP analysis for core 54 shows that there could be some water soluble silicon, which would be the silicate ion, $\mathrm{SiO}_{3}{ }^{2}$. Because the concentration is small, there would not be significant effect on the overall mass balance if some $\mathrm{SiO}_{2}$ were replaced by $\mathrm{SiO}_{3}{ }^{2}$. The effect on the charge balance would also be insignificant. In general, Si values are always somewhat suspect because Si present in laboratory glassware can be leached by the caustic waste samples.

Total inorganic carbon (TIC) is assumed to be carbonate.

Total organic carbon (TOC) is assumed to be acetate, $\mathrm{C}_{2} \mathrm{H}_{3} \mathrm{O}_{2}$.

Nitrite ion was determined by IC and by a spectroscopic (spec) method. The spec method gives anomalous results. It is suspected that there was a consistent error in the calculations for that method. If the spec result were substituted for the IC result in core 53 segment 1 , the mass balance would drop from $92.6 \%$ to $88.8 \%$, and the charge balance would increase from 0.99 to 1.35 . The other factor pointing to which of the $\mathrm{NO}_{2}{ }_{2}$ results is correct is simple knowledge of waste tank chemistry -- the spec result is not consistent with what is known about similar waste tanks.

Weight percent water (\% water) is a crucial factor in determining an accurate mass balance. The $\%$ water value for core $\mathbf{5 3}$ was taken from the thermogravimetric analysis result. For core 54 , the value reported as "\% Solids" was subtracted from 100 to arrive at \% water. 
Table 1. Concentrations As Reported in $\mu \mathrm{g} / \mathrm{g}$

\begin{tabular}{|c|c|c|c|c|c|c|}
\hline \multirow{2}{*}{ Analyte } & \multicolumn{3}{|c|}{ Core 53, Segment 1} & \multicolumn{3}{|c|}{ Core 54, Segment 1} \\
\hline & $\begin{array}{l}\text { Water } \\
\text { Digest }\end{array}$ & $\begin{array}{c}\text { Acid } \\
\text { Digest }\end{array}$ & Fusion & $\begin{array}{l}\text { Water } \\
\text { Digest }\end{array}$ & $\begin{array}{l}\text { Acid } \\
\text { Digest }\end{array}$ & Fusion \\
\hline Al & & 31,300 & 39,200 & 412 & 154,000 & 151,000 \\
\hline $\mathrm{Bi}$ & & 1,260 & 1,050 & N/A & 1,400 & 1,380 \\
\hline - $\mathrm{Ca}$ & & 1,500 & 5,050 & 457 & 1,330 & 2,290 \\
\hline $\mathrm{Cr}$ & & 726 & 613 & 95 & 2,894 & 252 \\
\hline $\mathrm{Fe}$ & & 45,500 & 40,600 & 18 & 9,090 & 25,500 \\
\hline $\mathrm{Mg}$ & & 1,030 & 1,250 & 22 & 1,100 & 957 \\
\hline Mn & & 19,900 & 17,900 & N/A & 3,330 & 2,810 \\
\hline $\mathrm{Na}$ & & 68,600 & 62,100 & 38,300 & 44,100 & 39.500 \\
\hline$P(I C P)$ & & 1,810 & 1,960 & 419 & 1.180 & 1,110 \\
\hline $\mathrm{Pb}$ & & 799 & 604 & N/A & 269 & 302 \\
\hline$S(I C P)$ & & 3,310 & 3,470 & 2,060 & 1,900 & 1,770 \\
\hline Si & & 2,250 & 7,760 & 1,000 & 72 & 6,200 \\
\hline TIC & 7,660 & & & 3,680 & & \\
\hline TOC & 4,130 & & & 5,060 & & \\
\hline$-\mathrm{Cl}^{-}$ & 510 & & & 294 & & \\
\hline $\mathrm{NO}_{2}^{-}$ & 37,800 & & & 21,800 & & \\
\hline $\mathrm{NO}_{2}^{\prime}$ (spec) & 276 & & & 713 & & \\
\hline $\mathrm{NO}_{3}^{-}$ & 26,900 & & & 15,500 & & \\
\hline $\mathrm{PO}_{4}^{3 \cdot}$ (IC) & 2.610 & & & 1,760 & & \\
\hline $\mathrm{SO}_{4}^{2-}(\mathrm{IC})$ & 10,800 & & & 6,250 & & \\
\hline$\%$ Water & & (from TGA & & 26.6 & rom \% Soli & \\
\hline
\end{tabular}


Table 2. Concentrations (in $\mu \mathrm{g} / \mathrm{g}$ ) As Used for Mass/Charge Balance

\begin{tabular}{|c|c|c|c|c|c|c|}
\hline \multirow{2}{*}{$\begin{array}{l}\text { Assumed } \\
\text { Species }\end{array}$} & \multicolumn{3}{|c|}{ Core 53, Segment 1} & \multicolumn{3}{|c|}{ Core 54, Segment 1} \\
\hline & Water Digest & $\begin{array}{l}\text { Acid } \\
\text { Digest }\end{array}$ & Fusion & $\begin{array}{l}\text { Water } \\
\text { Digest }\end{array}$ & $\begin{array}{c}\text { Acid } \\
\text { Digest }\end{array}$ & Fusion \\
\hline $\mathrm{Al}(\mathrm{OH})_{3}$ & & 90,500 & 113,000 & 1,190 & 445,000 & 437,000 \\
\hline $\mathrm{Bi}^{3+}$ & & 1,260 & 1,050 & $N / A$ & 1.400 & 1,380 \\
\hline $\mathrm{Ca}(\mathrm{OH})_{2}$ & & 2,770 & 9,340 & 845 & 2,460 & 4,230 \\
\hline $\mathrm{CrO}_{3}$ & & 1,400 & 1,180 & 183 & 546 & 485 \\
\hline $\mathrm{FeO}(\mathrm{OH})$ & & 72,400 & 64,600 & 29 & 14,500 & 40,600 \\
\hline $\mathrm{Mg}(\mathrm{OH})_{2}$ & & 2.470 & 3,000 & 53 & 2,640 & 2,300 \\
\hline $\mathrm{MnO}_{2}$ & & 31,500 & 28,300 & $\mathrm{~N} / \mathrm{A}$ & 5,270 & 4.450 \\
\hline $\mathrm{Na}^{+}$ & & 68,600 & 52,100 & 38,300 & 44,100 & 39,500 \\
\hline $\mathrm{PO}_{4}{ }^{3 \cdot}(\mathrm{ICP})$ & & 5,550 & 6.010 & 1,280 & 3,620 & 3.400 \\
\hline $\mathrm{PbO}_{2}$ & & 922 & 697 & N/A & 311 & 349 \\
\hline $\mathrm{SO}_{4}^{2 \cdot}(\mathrm{ICP})$ & & 9,930 & 10.400 & 6,180 & 5,700 & 5,310 \\
\hline $\mathrm{SiO}_{2}$ & & 4,820 & 16.600 & $2, i 40$ & 154 & 13,700 \\
\hline $\mathrm{CO}^{2}{ }^{2 \cdot}$ & 38,300 & & & 18,400 & & \\
\hline $\mathrm{C}_{2} \mathrm{H}_{3} \mathrm{O}_{2}$ & 10,200 & & & 12,400 & & \\
\hline $\mathrm{Cl}^{\circ}$ & 510 & & & 294 & & \\
\hline $\mathrm{NO}_{2}$ & 37,800 & & & 21,800 & & \\
\hline $\mathrm{NO}_{2}^{\circ}$ (spec) & 276 & & & 713 & & \\
\hline $\mathrm{NO}_{3}^{\circ}$ & 26,900 & & & 15,500 & & \\
\hline $\mathrm{PO}_{4}{ }^{3 \cdot}(\mathrm{IC})$ & 2,610 & & & 1.760 & & \\
\hline $\mathrm{SO}_{4}^{2 \cdot}(\mathrm{IC})$ & 10,800 & & & 6,250 & & \\
\hline$\%$ Water & \multicolumn{3}{|c|}{51.97 (from TGA) } & \multicolumn{3}{|c|}{26.61 (from \% Solids) } \\
\hline \multicolumn{2}{|c|}{ Mass Balance (\%) } & 92.6 & 95.0 & 38.5 & 86.1 & 88.7 \\
\hline \multicolumn{2}{|c|}{$\begin{array}{c}\text { Total Cations } \\
\text { (microequivalents) }\end{array}$} & 2.984 & 2.701 & 1,666 & 1,918 & 1.718 \\
\hline \multicolumn{2}{|c|}{$\begin{array}{c}\text { Total Anions } \\
\text { (microequivalents) }\end{array}$} & 3,026 & 3.026 & 1,742 & 1,742 & 1,742 \\
\hline \multicolumn{2}{|c|}{$\begin{array}{l}\text { Charge Balance } \\
\text { (Cations/Anions) }\end{array}$} & 0.99 & 0.89 & 0.96 & 1.10 & 0.99 \\
\hline
\end{tabular}

